\title{
The Ainsa Fold and thrust oblique zone of the central Pyrenees: Kinematics of a curved contractional system from paleomagnetic and structural data
}

\author{
Josep-Anton Muñoz, ${ }^{1}$ Elisabet Beamud, ${ }^{1,2}$ Oscar Fernández, ${ }^{3}$ Pau Arbués, ${ }^{1}$ \\ Jaume Dinarès-Turell, ${ }^{4}$ and Josep Poblet ${ }^{5}$ \\ Received 6 September 2012; revised 8 July 2013; accepted 1 August 2013; published 1 October 2013.
}

[1] Integration of structural, stratigraphic, and paleomagnetic data from the $\mathrm{N}-\mathrm{S}$ trending structures of the Ainsa Oblique Zone reveals the kinematics of the major thrust salient in the central Pyrenees. These structures experienced clockwise vertical axis rotations that vary from $70^{\circ}$ in the east (Mediano anticline) to $55^{\circ}$ in the west (Boltaña anticline). Clockwise vertical axis rotations of $60^{\circ}$ to $45^{\circ}$ occurred from early Lutetian to late Bartonian when the folds and thrusts of the Ainsa Oblique Zone developed. This vertical axis rotation stage resulted from a difference of about $50 \mathrm{~km}$ in the amount of displacement on the Gavarnie thrust and an accompanying change in structural style at crustal scale from the central to the western Pyrenees, related to the NE-SW trending pinch out of Triassic evaporites at its basal detachment. A second rotation event of at least $10^{\circ}$ took place since Priabonian, as a result of a greater displacement of the Serres Marginals thrust sheet with respect to the Gavarnie thrust sheet above the Upper Eocene-Oligocene salts. The deduced kinematics demonstrates that the orogenic curvature of the central Pyrenees is a progressive curvature resulting from divergent thrust transport direction. Layer parallel shortening mesostructures and kilometer-scale folds also developed by a progressive curvature related to divergent shortening directions during vertical axis rotation. Rotation space problems were solved by along-strike extension which triggered the formation of transverse extensional faults and diapirs at the outer arcs of structural bends.

Citation: Muñoz, J.-A., E. Beamud, O. Fernández, P. Arbués, J. Dinarès-Turell, and J. Poblet (2013), The Ainsa Fold and thrust oblique zone of the central Pyrenees: Kinematics of a curved contractional system from paleomagnetic and structural data, Tectonics, 32, 1142-1175, doi:10.1002/tect.20070.

\section{Introduction}

[2] Curved fold and thrust belts in map view are common features in orogenic systems [Macedo and Marshak, 1999; Marshak, 2004]. Their interpretation has concentrated the attention of many researchers in the last decades, mostly after the application of paleomagnetic techniques to unravel vertical axis rotations and decipher the displacement fields [Schwartz and Van der Voo, 1983; Allerton, 1998; Sussman and Weil, 2004; Soto et al., 2006; Weil et al., 2010].

\footnotetext{
Additional supporting information may be found in the online version of this article.

${ }^{1}$ Institut Geomodels, Departament de Geodinàmica i Geofísica, Facultat de Geologia, Universitat de Barcelona, Barcelona, Spain.

${ }^{2}$ Laboratori de Paleomagnetisme CCiTUB-CSIC, Institut de Ciències de la Terra "Jaume Almera", Barcelona, Spain.

${ }^{3}$ Repsol Exploración - Dirección de Geología, Madrid, Spain.

${ }^{4}$ Istituto Nazionale di Geofisica e Vulcanologia, Rome, Italy.

${ }^{5}$ Departamento de Geología, Universidad de Oviedo, Oviedo, Spain.

Corresponding author: J. A. Muñoz, Institut Geomodels, Departament de Geodinàmica i Geofísica, Facultat de Geologia, Universitat de Barcelona, Zona Universitària de Pedralbes, 08028 Barcelona, Spain. (jamunoz@ub. edu)

(C)2013. American Geophysical Union. All Rights Reserved. 0278-7407/13/10.1002/tect.20070
}

[3] Curved orogens or fold and thrust systems have been classified into primary, progressive, and secondary according to the timing between thrusting and rotation and the presence or absence of vertical axis rotation [Weil and Sussman, 2004; Weil et al., 2010].

[4] Primary arcuate fold and thrust systems formed originally with a curved geometry with no vertical axis rotation. They normally result from the inversion of a previous irregular fault or basin geometry. At the other end of the spectrum, secondary curved systems or oroclines are formed by the bending of initially linear structures about a vertical axis [Marshak, 2004]. Secondary curves caused by bending are characterized by vertical axis rotations that postdate the initiation of thrusting with a gradation of rotation directions and magnitudes around the salient and dependent on a second stage of deformation. Secondary curves caused by shearing are characterized by localized vertical axis rotations adjacent to the shear zones with possible rotations in the adjacent foreland. Vertical axis rotations occur during or after thrusting depending on the timing of the shear zone development and their magnitude decreases abruptly away from the shear zone. In progressive curved systems structures, the strike of structures changes progressively during deformation and can form by divergent thrust transport trajectories or by parallel 


\section{MUÑOZ ET AL.: PALEOMAGNETISM IN S PYRENEES}

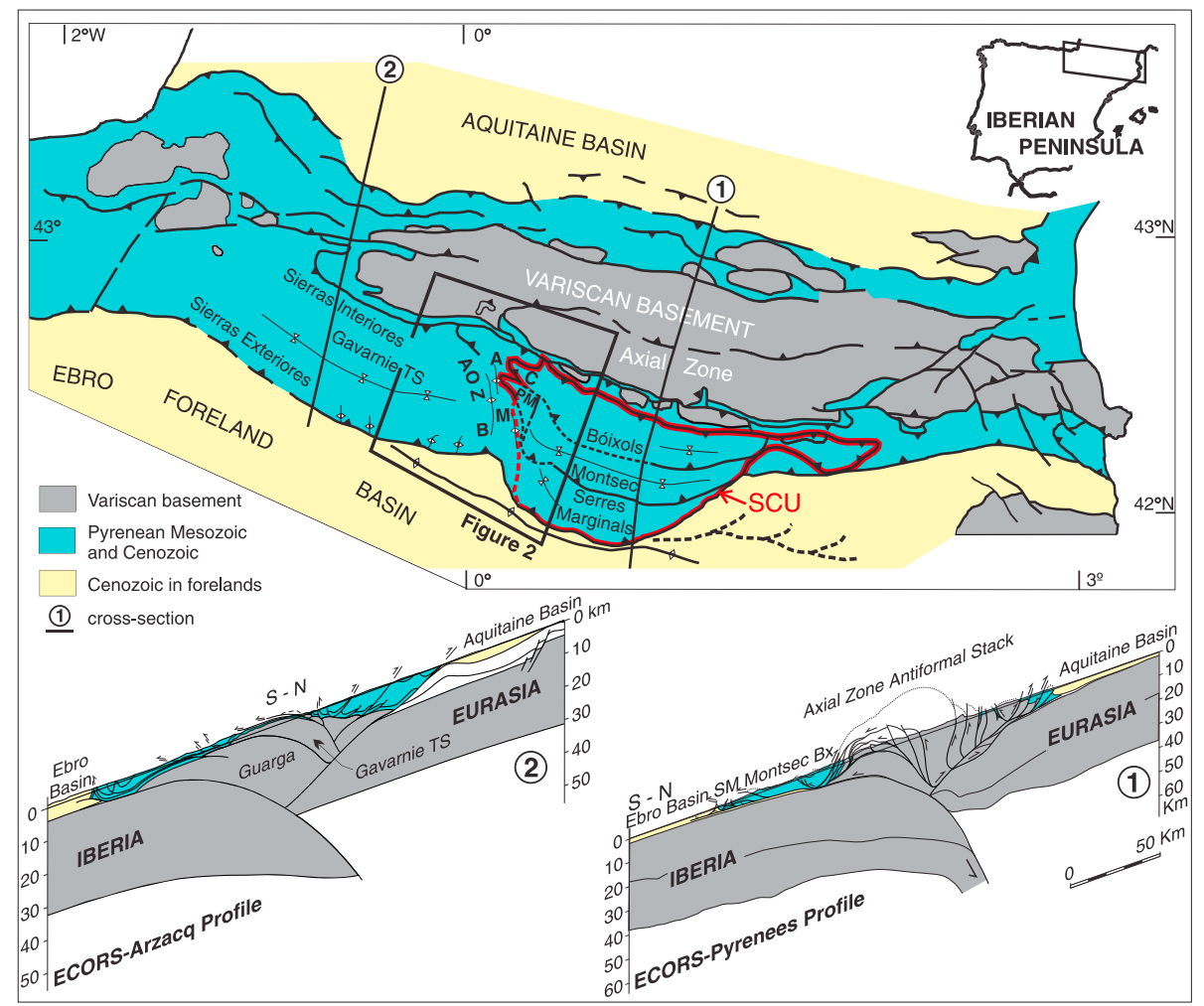

Figure 1. Location of the study area. Structural sketch showing the main structural units of the central Pyrenees and the major anticlines of the Ainsa Oblique Zone at the western boundary of the major thrust salient in the central Pyrenees. Crustal cross sections at both sides of the Ainsa Oblique Zone illustrate changes of the structural style along strike. Etude Continentale et Océanique par Reflexion et Refraction Sismique (ECORS) section (1) from Muñoz [1992] and the Arzacq section (2) modified from Teixell [1998]. AOZ, Ainsa Oblique Zone; A, Añisclo Anticline; B, Boltaña Anticline; M, Mediano Anticline; C, Cotiella; PM, Peña Montañesa; SCU, South Pyrenean Central Unit; Bx, Bóixols; SM, Serres Marginals.

slip showing an along-strike displacement gradient during thrusting [Elliot, 1976]. In such cases rotation and thrusting occur simultaneously [Weil et al., 2010].

[5] The southern Pyrenees show numerous oblique and transversal structures (Figure 1) that have been interpreted as a result of primary, progressive, or secondary curves. In order to explain the observed curvature and the oblique structures, practically all the possible models have been proposed: primary curvature inherited from the geometry of Mesozoic Basins [Vergés, 1993; Larrasoaña et al., 2003], primary oblique structures developed by along-strike mechanical contrasts in the detachment level [Storti et al., 2007; Vidal et al., 2009], primary to progressive curvature triggered by thickness differences of the inverted basins with no significant vertical axis rotations [Soto et al., 2002], progressive curvature formed by lateral gradients of thrust displacement with constant transport direction [Sussman et al., 2004], and secondary curvatures due to superimposed folding [Garrido-Megías, 1973; Megías, 1982], among others.

[6] Each of these models predicts different kinematic histories that can be compared with structural and paleomagnetic data. Distribution and magnitude of vertical axis rotations are normally determined by paleomagnetic studies, which provide the most robust data to distinguish between the different types of orogenic curvature [Soto et al., 2006; Weil et al., 2010]. Nevertheless, due to the common protracted deformation history found in most orogens, caution is needed to accurately interpret paleomagnetic data and the timing of the magnetization with respect the structural evolution should be considered.

[7] A better understanding of the kinematic evolution and processes that produce fold and thrust curved patterns can be achieved by integrating internal deformation data with paleomagnetic studies [Hindle and Burkhard, 1999; Yonkee and Weil, 2010a; Weil et al., 2010].

[8] A significant amount of paleomagnetic studies have been published in the Central Pyrenees aiming not only to date the well-preserved synorogenic successions but also to decipher vertical axis rotations. The combination of magnetostratigraphic [Bentham and Burbank, 1996; Hogan and Burbank, 1996; Beamud et al., 2003; Oms et al., 2003; Mochales et al., 2012a; Rodríguez-Pintó et al., 2012; Rodríguez-Pintó et al., 2013] and magnetotectonic studies [Dinarès-Turell, 1992; Pueyo, 2000; Pueyo et al., 2002, 2003a, 2004; Mochales et al., 2012b] has revealed the existence of significant vertical axis rotations as well as their chronology and relationships with the main structures.

[9] Clockwise vertical axis rotations have been documented by several paleomagnetic studies in the south western central Pyrenean area, including not only the study area (Ainsa Basin) but also the structures located westward in the Sierras Exteriores (Figure 2) [Dinarès-Turell, 1992; Pueyo, 2000; Pueyo et al., 2002, 2004; Fernández-Bellon, 2004; Rodriguez-Pintó et al., 2013; Mochales et al., 2012b; 


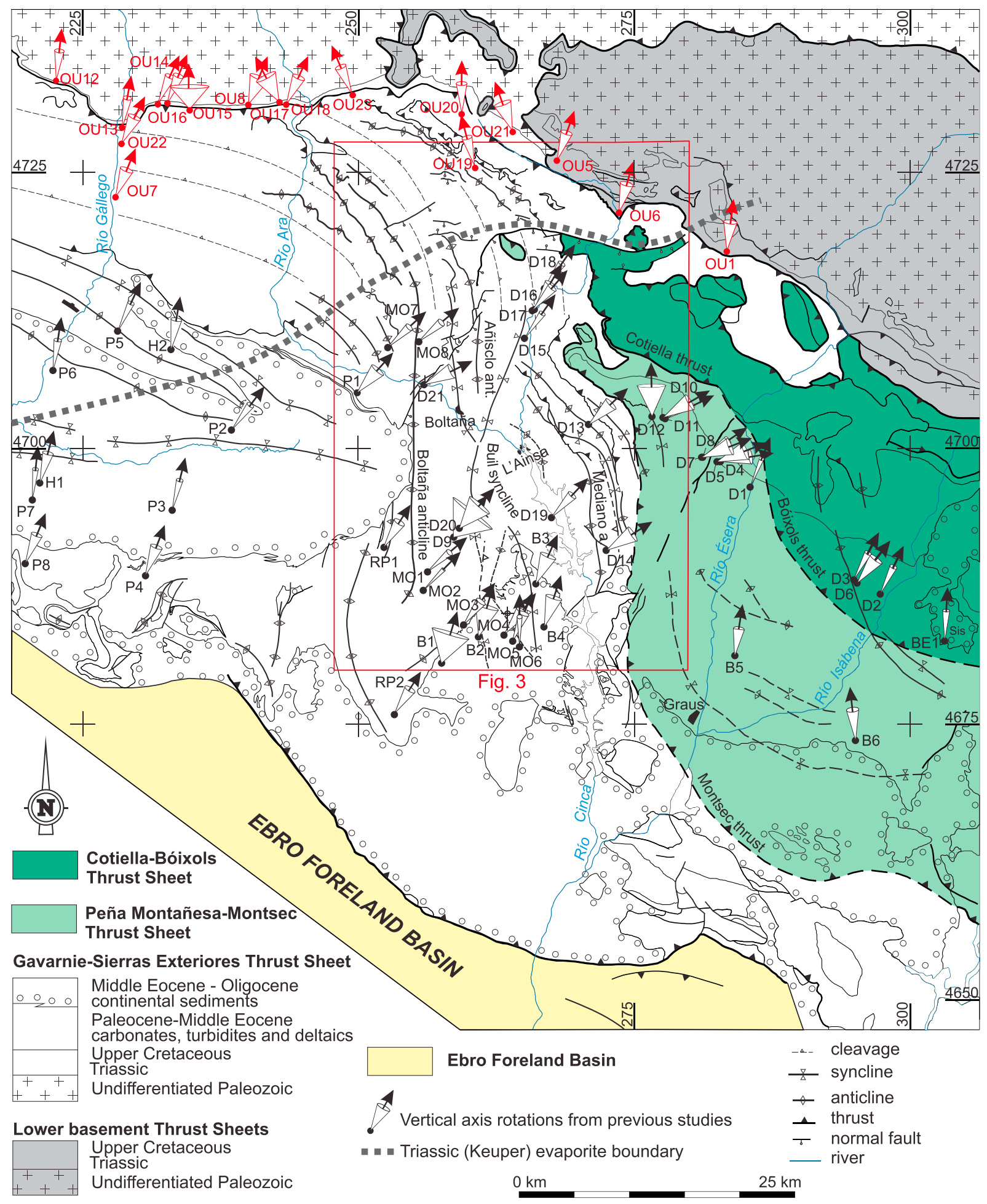

Figure 2. Structural map of the Ainsa Oblique Zone and surrounding areas. Location of the paleomagnetic sites with mean values of rotation from previous studies (B, Bentham [1992]; BE, Beamud et al. [2003]; D, Dinarès-Turell [1992]; H, Hogan [1993]; MO, Mochales et al. [2012b]; OU, Oliva-Urcia and Pueyo [2007a, 2007b]; P, Pueyo et al. [2003a]; RP, Rodríguez-Pintó et al. [2013]). Cones represent $\alpha_{95}$ values of the paleomagnetic directions. Red sites correspond to remagnetized sites from Oliva-Urcia [2004]. See location in Figure 1 and data in Table S1 of supporting information. Red square indicates the position of the study area represented in Figure 3. 
Oliva-Urcia et al., 2012a; Ramón et al., 2012]. Such clockwise rotations explain the occurrence of N-S to NWSE structures that are oblique to the main WNW-ESE Pyrenean trend that characterizes the southern Central Pyrenees. Vertical axis rotations account for progressive or secondary curvature and have been explained by differential displacement of the South Pyrenean thrust sheets [Soto et al., 2006; Oliva-Urcia and Pueyo, 2007a].

[10] The oblique structures of the South Central Pyrenees have also been the focus for studies of internal strain [Holl and Anastasio, 1995a] and mesostructural analysis [Holl and Anastasio, 1995b; Tavani et al., 2006, 2012], which together with recent studies on anisotropy of magnetic susceptibility (AMS) [Oliva-Urcia et al., 2009; Mochales et al., 2010] add further constraints in the understanding of the kinematic evolution of these structures.

[11] The structures in the Ainsa Basin define the most prominent fold and thrust curvature in the Central Pyrenees (Figure 1). It is an excellent location to study kinematics of orogenic curvature because of (i) the quality of exposures, (ii) the access to different structural levels due to a late structural tilting, (iii) the time constraints yielded by the unique preservation of growth strata, and (iv) the available subsurface data (exploration wells and seismic sections).

[12] However, despite the amount of studies done in the area dealing with different disciplines, there is not yet a comprehensive model that honors all the available sedimentological, structural, and paleomagnetic data. The study presented here builds on previous published works as well as on the work done in the area of the Ainsa Basin by the authors in the last two decades on sedimentology of the different involved sedimentary systems [Arbués et al., 2011], 3-D structural reconstruction of the entire basin [FernándezBellon, 2004; Fernández et al., 2004, 2012], tectonosedimentary relationships [Muñoz et al., 1994, 1998; Poblet et al., 1998], mesostructural analysis [Tavani et al., 2006, 2012], and paleomagnetic studies [Dinarès-Turell, 1992; Beamud et al., 2003; Fernández-Bellon, 2004]. By integrating these studies, we reduce the limitations of the interpretations based on individual data sets. In this paper we bring new paleomagnetic and structural data and present a new model for the kinematics of the entire Ainsa Fold and thrust oblique zone. Our work pretends to gain insight into a better understanding of the three-dimensional kinematic evolution and processes that produce orogenic curvature.

[13] The study area has the additional interest of the interaction between slope to deltaic sedimentary systems and the evolving structural topography from a deep water to an emergent fold and thrust belt. This extraordinary tectono-sedimentary variety and the outcrop quality make that area a superb natural laboratory. The Ainsa Basin is well known among the geological community for the sedimentary models of turbidite systems and their related fluvio-deltaic and carbonate platform systems [Mutti et al., 1988]. However, little is known yet about the kinematic 3-D evolution of the structures that developed during the sedimentation of the Ainsa Basin infill. This is fundamental for the proper understanding of the facies arrangement and internal architecture of the Ainsa Basin slope and deltaic sediments which are a reference among sedimentologists for turbidite facies models and field analogs for exploration and production purposes [e.g., Falivene et al., 2010]. Results of our work add new constraints for the understanding of the sedimentary pathways and sedimentary dispersal of the slope systems of the Ainsa Basin.

\section{Geological Setting}

[14] The Pyrenean orogen formed as the result of the collision between the Iberian and European plates from Late Cretaceous to Miocene times [Roest and Srivastava, 1991; Muñoz, 2002; Rosenbaum et al., 2002]. It is an asymmetric doubly vergent orogenic wedge that resulted from the subduction of the Iberian lithospheric mantle and lower crust under the European plate and the thrusting of upper crustal rocks to the north and south (Figure 1) [Muñoz, 1992]. Shortening along the central sector totals approximately $150 \mathrm{~km}$ (147 km according to Muñoz [1992], $165 \mathrm{~km}$ according to Beaumont et al. [2000]) with a transport direction to the south [Vergés, 1993; Rosenbaum et al., 2002]. The Pyrenees, with a regional WNW-ESE trend, consist of a central duplex of south directed Variscan basement thrust sheets (referred to as the Axial Zone) which are flanked to north and south by oppositely vergent fold and thrust belts and associated foreland basins (Figure 1). The southern fold and thrust belt are formed by a set of imbricate thrust sheets of Mesozoic and Tertiary cover rocks that developed from Late Cretaceous to Oligocene times in a piggyback sequence over the autochthonous rocks of the Ebro foreland Basin [Séguret, 1972; Garrido-Megías, 1973; Cámara and Klimowitz, 1985; Muñoz, 1992]. Syntectonic Eocene-Oligocene sedimentation and burial of the frontal thrust sheets promoted synchronous thrusting of the south Pyrenean thrust wedge. As a result, previously developed thrusts were locally reactivated as out-of-sequence thrusts [Muñoz et al., 1997; Muñoz, 2002].

[15] Three major cover thrust sheets constitute the southern fold and thrust belt. From north to south (and in order of emplacement), these thrust sheets are (Figures 1 and 2) the Cotiella-Bóixols thrust sheet developed during the Late Cretaceous, the Peña Montañesa-Montsec thrust sheet formed during the Paleocene-late Ypresian, and the Sierras Exteriores-Serres Marginals thrust sheet developed during Lutetian-Oligocene times. Southward displacement on the cover thrust sheets is fed by basement thrusts in the Axial Zone [Séguret, 1972; Cámara and Klimowitz, 1985]. In the case of the Sierras Exteriores-Serres Marginals, displacement is mainly accounted for by the Gavarnie, Bielsa, and Guarga basement thrusts that moved mostly diachronously and in succession [Séguret, 1972; Cámara and Klimowitz, 1985; Martínez-Peña and Casas-Sainz, 2003]. The Gavarnie thrust started to develop during early Lutetian times (the age of the onset of folding in its hanging wall) [Séguret, 1972; Fernández et al., 2012], feeding displacement along the Sierras Exteriores thrust in its leading edge in what Labaume et al. [1985] called the Gavarnie Nappe (referred to as the Gavarnie or Gavarnie-Sierras Exteriores thrust sheet in this article). Displacement continued until it was tilted, folded, and passively transported southward from Late Eocene times by the Guarga and related basement thrusts (Figure 1) in what Labaume et al. [1985] called the Gavarnie Detachment Unit (referred to as the Sierras Exteriores thrust in this article). The Late Eocene-Oligocene age of the Guarga thrust is demonstrated by the relationships between the basement 
cutoff line in its hanging wall and the Guarga synclinorium [Fernández et al., 2012] and the age of the growth strata preserved in its core [Puigdefàbregas, 1975; FernándezBellon, 2004]. Motion on deep post-Gavarnie thrust sheets was responsible for the Late Eocene-Oligocene structures observed in the Jaca Basin and Sierras Exteriores [Labaume et al., 1985; Teixell, 1996] which have been erroneously used to date motion on the Gavarnie thrust.

[16] The main thrust sheets of the south central Pyrenees described above were considered to form a major structural unit referred to as the South Pyrenean Central Unit [Séguret, 1972] (Figure 1). The western boundary of this unit was interpreted to correspond to the $\mathrm{N}-\mathrm{S}$ trending folds of the Ainsa area studied in this paper. However, there was no consensus among geologists on the location or nature of such boundary. Some authors considered it was located in the Mediano Anticline [Séguret, 1972] while others placed it further west, along the Boltaña Anticline [Soto et al., 2002] (Figure 1). Detailed 3-D reconstruction of the area-integrating surface and seismic data [Fernández-Bellon, 2004; Fernández et al., 2004, 2012] revealed that these folds are part of the Gavarnie-Sierras Exteriores thrust sheet, which represents the westward continuation of the Serres Marginals thrust sheet. The absence of any major lateral structure between the Sierras Exteriores and Serres Marginals thrust sheets means that the South Pyrenean Central Unit as defined by Séguret [1972] is not a structural unit; in consequence, referring to the oblique Ainsa Folds as its western limit is not applicable.

[17] Nonetheless, a major structural change does occur between the central and the west central southern Pyrenees. In the central Pyrenees, east of the studied area, the basement thrust sheets form an antiformal stack with a significant structural relief [Muñoz, 1992]. Southward, the Mesozoic cover sequence is detached along the Triassic evaporites to form the Bóixols, Montsec, and Serres Marginals thrust sheets (Figure 1 and section 1). In the Axial Zone, Triassic evaporites also decouple Mesozoic units from the antiformally stacked basement units. On the contrary, in the west central Pyrenees there are no Triassic evaporites between Upper Cretaceous and Paleozoic rocks along the Axial Zone. As a result, the Mesozoic and Paleogene covers are coupled to the basement and basement thrust sheets are mostly imbricated, instead of piled one on top of the other, constituting an imbricate hinterland dipping duplex [Cámara and Klimowitz, 1985; Labaume et al., 1985; Teixell, 1996, 1998]. The change in thrusting geometry in turn leads to a more distributed structural relief in the west central Pyrenees. As basement thrust sheets are located further south in the west central than in the central Pyrenees, the cover thrust sheets are widely exhumed in the west. Thus, the western lateral equivalents of the Peña Montañesa-Montsec and CotiellaBóixols thrusts have been uplifted and eroded, whereas the lower Gavarnie-Sierras Exteriores thrust sheet occupies a wide area (Figure 1), only disrupted along its northern edge by a minor fold and thrust system (Larra-Monte Perdido, Figure 3) in the footwall of the eroded Peña Montañesa thrust. As a consequence of the changes in thrust geometry and imbrication, the basement thrust sheets along the Axial Zone plunge westward and the structural relief decreases in the same direction (Figure 1 and sections 1 and 2). The change in structural relief is not sharp and occurs across a wide area that coincides with the extent of the $\mathrm{N}-\mathrm{S}$ trending structures of the studied area. The significance of these changes in the geometry of the Axial Zone and cover thrust sheets, as well as their structural expression, will be discussed herein.

[18] Major thrusts and related folds and cleavage of the Ainsa Basin in the Gavarnie thrust sheet display a regional curvature from WNW trends in the northwestern part to $\mathrm{N}$ trends in the central part of the Ainsa Basin [Choukroune and Séguret, 1973] to define what is referred to in this paper as the Ainsa Oblique Zone (Figures 1 and 2). The transition from this zone to the WNW Pyrenean trends of the TrempGraus piggyback Basin and Serres Marginals eastward is concealed by synorogenic sediments and overprinted by salt structures (Figures 2 and 3).

\section{Stratigraphy and Structure of the Study Area}

[19] The most conspicuous structural feature of the Ainsa Basin is a system of kilometer-scale $\mathrm{N}-\mathrm{S}$ trending folds in the footwall of the Cotiella and Peña Montañesa-Montsec thrust sheets (Figures 1, 2, and 3), referred to as the Sobrarbe fold system [Fernández-Bellon, 2004; Fernández et al., 2012]. These folds are detachment to fault propagation folds, which detached into the Triassic evaporites and deform the Upper Cretaceous-Paleogene stratigraphic succession of the Gavarnie thrust sheet. In addition to the Sobrarbe fold system, the sediments of the Ainsa Basin are deformed in its proximal area, adjacent to the Peña Montañesa-Montsec thrust sheet, by a deep water fold and thrust system which has been named La Fueba thrust system [Fernández-Bellon, 2004; Fernández et al., 2012]. All these structures display curvature in map view over a range of scales.

\subsection{Tectonostratigraphic Units}

[20] The oldest rocks outcropping north of the study area are Devonian and Carboniferous shales, sandstones, and limestones which constitute the Variscan basement of the Gavarnie thrust sheet [Ríos Aragüés et al., 1982a]. Unconformably above, Triassic sediments are irregularly distributed. Upper Triassic Keuper shales, evaporites, and salts are truncated westward below the unconformity at the bottom of the Upper Cretaceous limestones, defining a NNE-SSW trending edge (Figure 2). Such sediment distribution controlled the structural evolution of the area as will be discussed later. In the study area, lower Triassic red beds (Buntsandstein facies) are only observed in the footwall of the Gavarnie thrust sheet, unconformably overlying the post-Variscan granites [Ríos Aragüés et al., 1982a].

[21] Unconformably above the Triassic reds beds, evaporites, and salt, or directly on top of the Variscan basement rocks, the stratigraphic succession of the study area consists of the following main tectonostratigraphic units (Figure 4): (1) Upper Cretaceous limestones, marls, and calcarenites, (2) Paleocene carbonates and clastic sediments, (3) the Lower Eocene Alveolina Limestone and a succession of marls and limestones above, (4) Lower Eocene (Cuisian) Alveolina and Nummulitid limestones (Santa Marina Fm.) which are the lateral equivalent of the lower part of the Ainsa slope complex (San Vicente Fm. 1), (5) Middle Eocene platform limestones (Guara Fm.) and the lateral equivalent upper part of the Ainsa slope complex (San Vicente Fm. 2), (6) Middle-Upper Eocene deltaic (Sobrarbe Fm.) to continental sediments (Escanilla Fm.), and (7) Oligocene-Miocene continental deposits. 


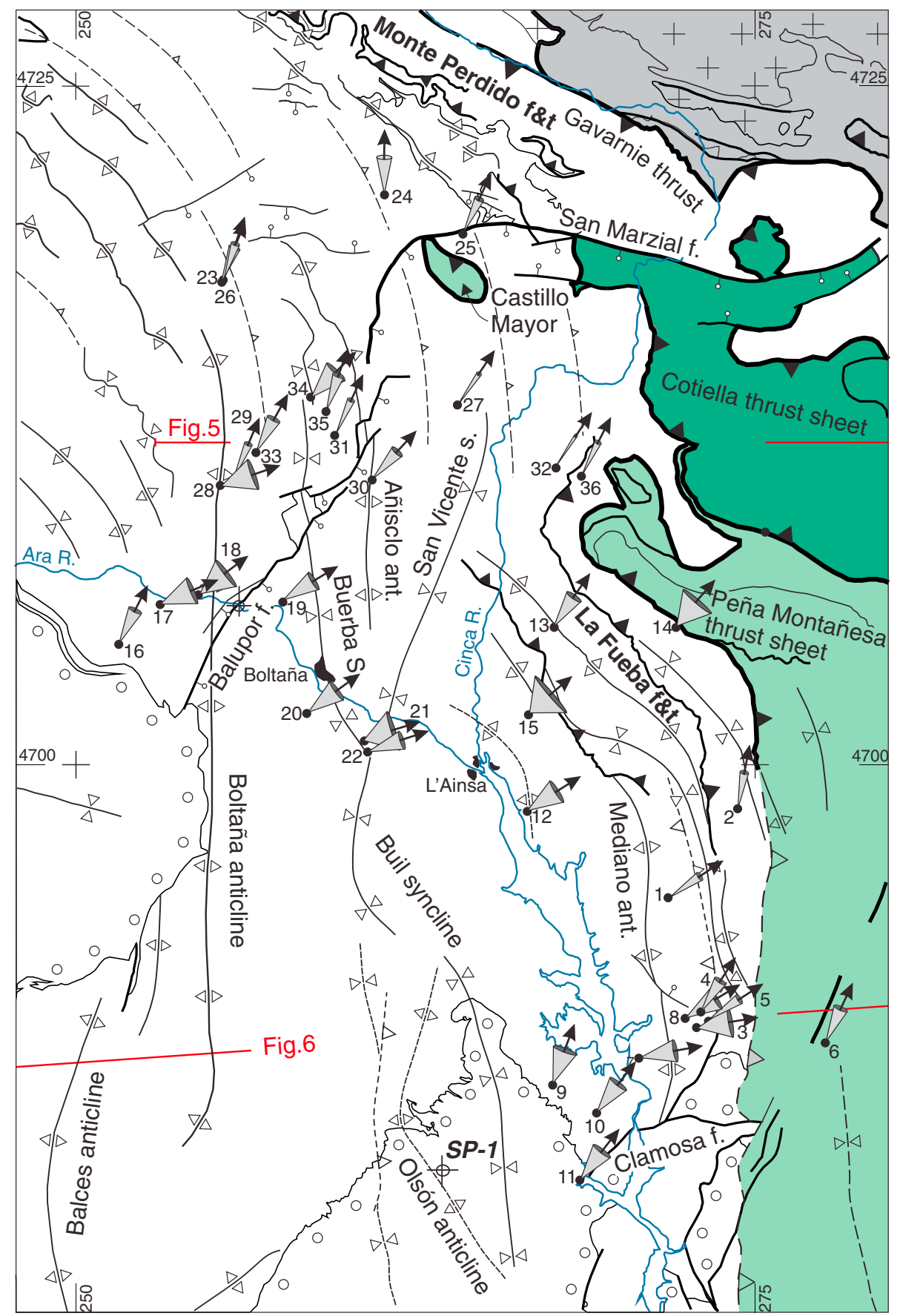

Figure 3. Paleomagnetic sites and vertical axis rotations within the study area. See location in Figure 2. Cones represent the declination error obtained from $\alpha_{95} / \cos I$. The map legend is the same as in Figure 2. Red lines indicate the location of the cross sections presented in Figures 5 and 6. F, fault; f\&t, fold and thrust system; ant, anticline; s, sincline.

[22] The Upper Cretaceous succession of the Gavarnie thrust sheet consists of two tectonostratigraphic subunits. The lower one is made up by upper Cenomanian-lower Santonian limestones ("Calcaires des Canyons") [Fournier, 1905] that represent the post rift succession on the margin of the Lower Cretaceous rift, which was located to the NE of the studied area. They thin from a few hundreds of meters in the northwest, where they unconformably overlay the basement rocks of the Gavarnie thrust sheet, to few tens of meters in the south, on top of the Triassic evaporites (as evidenced by the borehole Surpirenaica-1 [Lanaja and Navarro, 1987] and the outcropping core of the Mediano anticline [Garrido-Megias, 1973]). Next to the rift margin, they reach a thickness up to $5 \mathrm{~km}$ in the Cotiella thrust sheet [Garcia-Senz, 2002; McClay et al., 2004]. Above, the younger upper Santonian-Maastrichtian subunit developed in a foreland basin setting during the inversion of the CotiellaBóixols thrust sheet [Garcia-Senz, 2002]. Thickness of these Upper Cretaceous synorogenic sediments varies from up to $3 \mathrm{~km}$ in the Montsec thrust sheet, to $500-700 \mathrm{~m}$ in the 


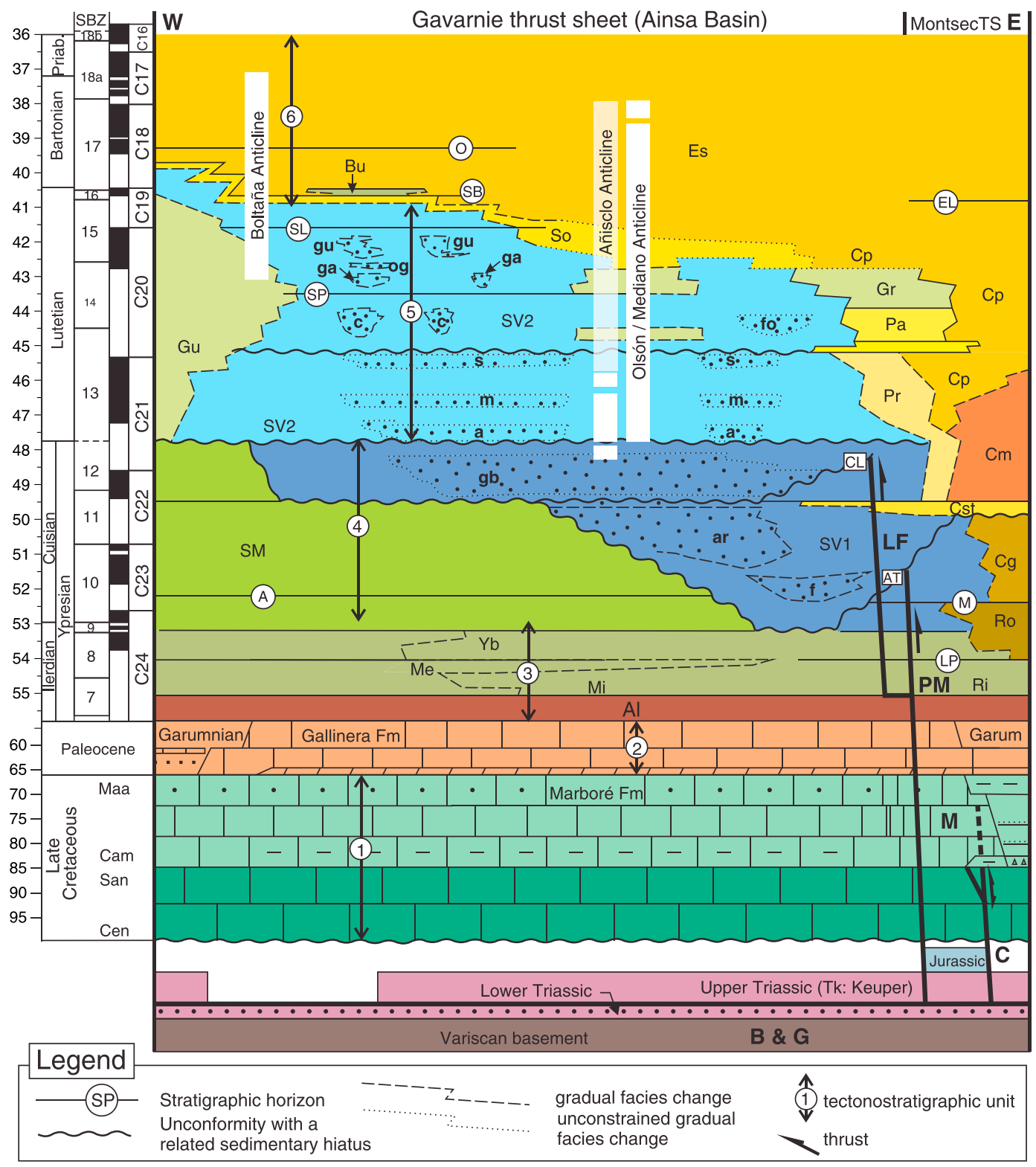

Figure 4. Chronostratigraphic diagram showing the main stratigraphic units of the Gavarnie thrust sheet and surroundings. Lithostratigraphic units: Es, Escanilla; Bu, Buil; So, Sobrarbe; Gu, Guara; Gr, Grustán; Pa, Pano; Cp, Capella; Pr, Perarrúa; Cm, Campanué; Cst, Castissent; SM, Santa Marina; Cg, Castigaleu; Ro, Roda; Yb, Yeba; Ri, Riguala; Me, Metils; Mi, Millaris; Al, Alveolina limestone. SV12: San Vicente Formation. Turbidite systems: gu, Guaso; og, O Grao; ga, Gabardilla; c, Coscojuela; fo, Formigales; s, Sieste; m, Morillo; a, Ainsa; gb, Gerbe-Banastón; ar, Arro; f, Fosado. Horizons: O, Olsón; EL, Escanilla limestone; SB, Santa Bárbara; SP, San Pedro; SL, San Lino; M, Morillo limestone; A, Ascaso; LP, La Puebla. Thrust sheets: C, Cotiella; M, Montsec; PM, Peña Montañesa; B \& G, Bielsa and Guarga; LF, La Fueba thrust system. Unconformities: AT, L'Atiart; CL, Charo-Lascorz. Litho- and chronostratigraphic information compiled from Bentham et al. [1992], Bentham and Burbank [1996], Barnolas and Gil-Peña [2001], López-Blanco et al. [2003], Mochales et al. [2012a], Rodríguez-Pintó et al. [2012], and Serra-Kiel et al. [1994]. Eocene time scale from Gradstein et al. [2004]. SBZ biozones calibration to the time scale integrates data from Costa et al. [2013] and Rodríguez-Pintó et al. [2012].

Gavarnie thrust sheet, or few tens of meters in the most frontal thrusts sheets of the Sierras Exteriores.

[23] Upper Cretaceous rocks are overlain by 100 to $400 \mathrm{~m}$ of Paleocene shallow water limestones and dolomites which grade in the SE corner of the studied area (Mediano anticline) into a succession of red beds and fresh water limestones
(Garumnian facies). This transition is also observed in the Montsec thrust sheet east of the Esera Valley [Baceta et al., 2004; Robador, 2008] (Figure 2). The lower Ilerdian is represented in the Ainsa Basin area by the Alveolina Limestone [Mey et al., 1968]. This formation represents a widespread transgressive episode event in the south Pyrenean foreland 


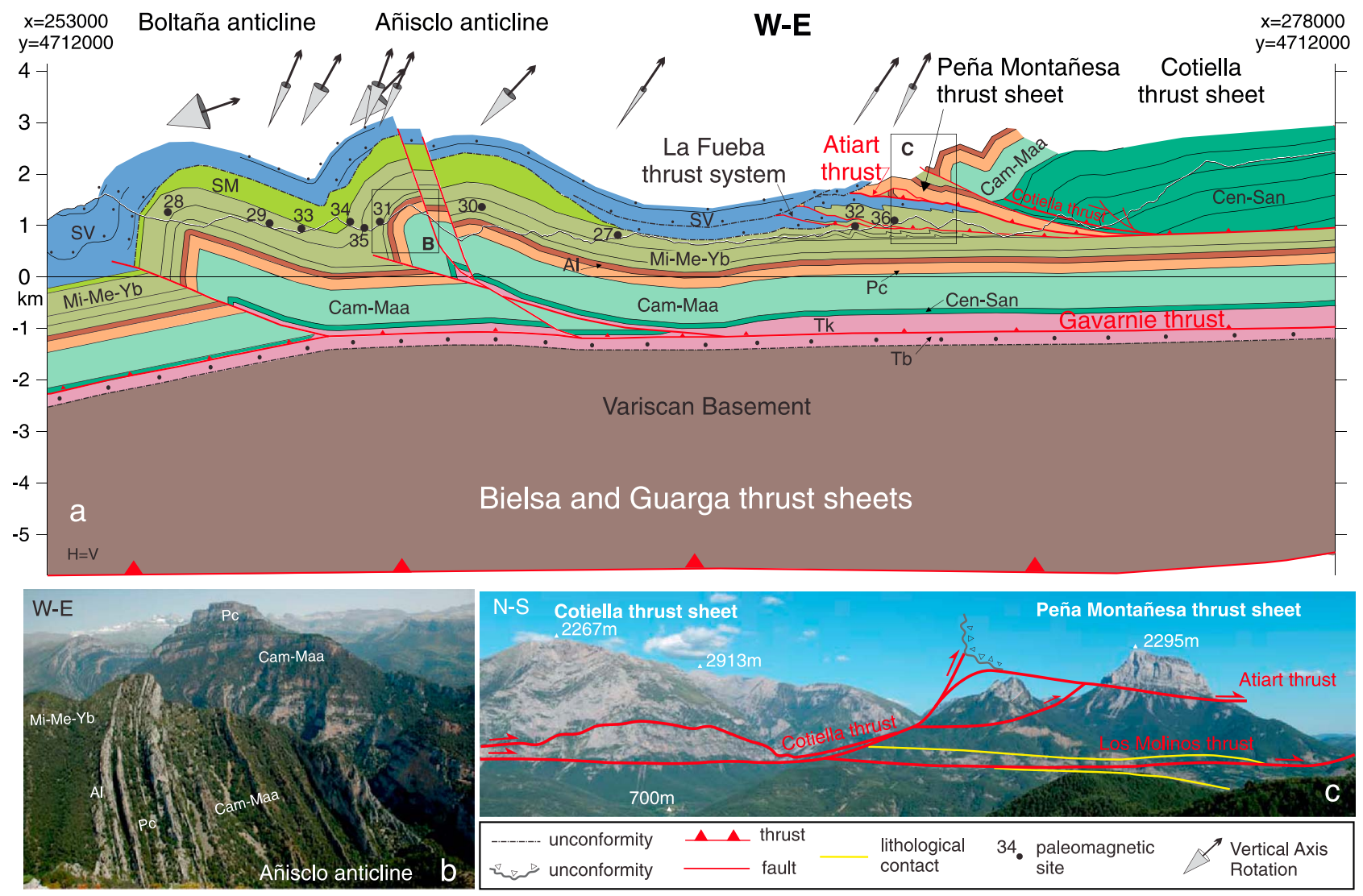

Figure 5. (a) Cross section of the northern part of the Ainsa Oblique Zone, across the Boltaña and Añisclo anticlines in the Gavarnie thrust sheet and the Peña Montañesa and Cotiella thrust sheets. Lithostratigraphic units like in Figure 4. (b) Photograph of the Añisclo anticline. (c) Photograph and structural sketch of the Peña Montañesa and Cotiella thrust sheets.

Basin. Its thickness ranges from 70 to $150 \mathrm{~m}$ and coincides with the end of a relatively quiescent period which started in Paleocene times. Above, a succession of marls and limestones completes the lower Eocene series (Millaris, Metils, and Yeba Fms.) [Van Lunsen, 1970; Barnolas and Gil-Peña, 2001; Mochales et al., 2012a] (Figure 4).

[24] The Ainsa slope complex is as much as a $4 \mathrm{~km}$ thick succession of primarily mudstones with several encased turbidite systems, each one being a few hundreds of meters thick [Arbués et al., 2007]. These sediments, described as the San Vicente Formation [Van Lunsen, 1970; De Federico, 1981], are the main infill of the well-known Ainsa Basin and represent the proximal slope facies of the deeper water siliciclatic complexes in the Jaca Basin, located westward (Hecho Group) [Mutti et al., 1972].

[25] The Lower Eocene part of the Ainsa slope complex developed in the footwall of the Peña Montañesa-Montsec thrust sheet in a foredeep setting (Figures 2, 4, 5, and 6). Sedimentation occurred synchronously with the La Fueba deep water fold and thrust system in the footwall of the Peña Montañesa-Montsec thrust as its hanging wall was displaced southward [Muñoz et al., 1994]. The slope sediments were primarily fed from a fluvio-deltaic complex located in the east, on top of the Montsec thrust sheet (the Montañana Group of the Graus-Tremp piggyback Basin) [Nijman and Nio, 1975]. Southward, the turbiditic trough of the Ainsa Basin was bounded by a carbonate platform (Santa Marina Fm.)
[Barnolas et al., 1991]. This platform retreated in front of the Peña Montañesa-Montsec thrust sheet as the thrust sheet moved southward. Slope sediments onlap the back-stepped margin of the platform and incorporate resedimented carbonates triggered by the tilting of the platform [Arbués et al., 2011].

[26] At Middle Eocene times, deformation progressed into the footwall of the Peña Montañesa thrust sheet. As a result, the Gavarnie thrust sheet developed and the floor of the Ainsa Basin was deformed by the Sobrarbe fold system (Figures 5 and 6). The Ainsa Basin changed from a foredeep to a piggyback basin, and its infill developed a shallowing upward sequence. The upper parts of the slope complex and its carbonate and deltaic equivalents as well as the fluvio-deltaic complex above (Sobrarbe deltaic system and Escanilla Fm.) [Dreyer et al., 1999] were sedimented during fold growth [Poblet et al., 1998]. Westward, the fluvial red beds of the Escanilla Fm. grade laterally into the deltaic sandstones of the Sobrarbe delta, which in turn are the lateral equivalent of the upper part of the slope sediments of the San Vicente Fm. (Figure 4).

[27] The youngest marine sediments in the studied area correspond with the Buil Nummulitic Banks at the bottom of the Escanilla Fm. [Mateu-Vicens et al., 2012]. Above, fluvial sediments of the Escanilla Fm. are Bartonian to Priabonian in age [Bentham, 1992; Bentham et al., 1992; Mochales et al., 2012a]. The middle to upper part of the Escanilla Fm. is equivalent to the Campodarbe Group [Puigdefàbregas, 1975], 


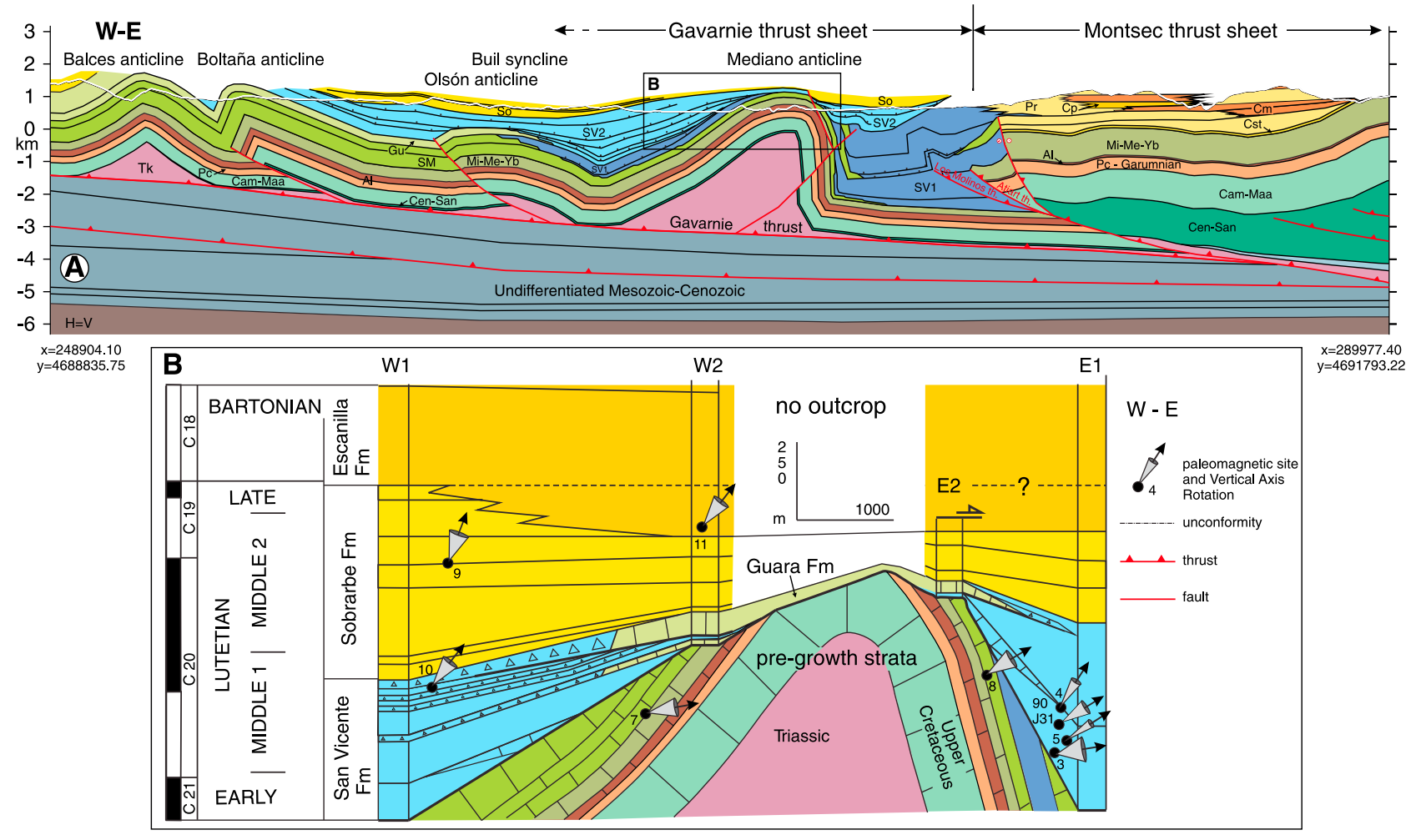

Figure 6. (a) Cross section of the southern part of the Ainsa Oblique Zone. Lithostratigraphic units like in Figure 4. (b) Enlargement of the Mediano anticline (base of the Escanilla Fm. restored to horizontal) and location of the paleomagnetic sites with respect to the synfolding growth sequence. W1, W2, E1, and E2 correspond to four stratigraphic columns constructed across the growth sequence, two of them in the west limb and two of them in the east limb of the anticline.

which lies unconformably on top of the Middle Eocene limestones on the western limb of the Boltaña anticline (Figure 2).

[28] The Escanilla Fm. and older formations are unconformably overlain by the Oligocene-Miocene continental sediments, which extensively cover the southern part of the studied area [Puigdefäbregas, 1975; Luzón, 2005] (Figure 3). These sediments consist of conglomerates at the northern margin of the basin passing southward into sandstones and mudstones. They were deposited synchronously with the frontal thrust structures [Luzón, 2005].

\subsection{The Sobrarbe Fold System}

[29] The Sobrarbe fold system consists of four major N-S trending anticlines, which from east to west are the Mediano, Olsón, Añisclo, and Boltaña anticlines. Between them, synclines occur, the most prominent of which is the Buil syncline (Figures 2 and 3). These folds have been described by many authors due to the high obliquity of their trends with respect the main E-W to ESE-WNW Pyrenean structural trend [Séguret, 1972; Garrido-Megías, 1973; Puigdefàbregas, 1975; Mutti et al., 1988; Martínez Peña, 1991; Soto and Casas, 2001; Soto et al., 2002]. Fernández et al. [2012] have recently described in detail the 3-D geometry of these folds based on the integration of surface and subsurface data, following a fully 3-D reconstruction approach [Fernández et al., 2004].

[30] The Mediano anticline is a $20 \mathrm{~km}$ long detachment fold cored by Triassic evaporites. Its structure and along-strike evolution were described by Poblet et al. [1998]. In its southern sector, it displays eastward vergence (Figure 6) and a northward plunge of about $10^{\circ}$. It is bound to the south by the faults bounding the Clamosa Triassic salt dome [Teixell and Barnolas, 1995]. To the north, the Mediano anticline changes to a NW-SE trend before terminating below the turbidites of the Ainsa Basin (Figures 2 and 3). The Mediano anticline has been considered as an oblique structure related to the Montsec thrust [Farrell et al., 1987; Martínez-Peña, 1991; Bentham and Burbank, 1996] or as a structure belonging to the Montsec thrust sheet [Soto et al., 2002; Mochales et al., $2012 \mathrm{~b}]$. However, the Mediano anticline is younger than the Montsec thrust. Growth geometries clearly demonstrate that the Mediano anticline developed during the Middle Eocene, from early Lutetian to Bartonian times [Poblet et al., 1998], whereas the Montsec thrust and its northern continuation into the Atiart thrust are unconformably overlain by late Ypresian sediments [Soler-Sampere and Garrido, 1970; GarridoMegías, 1973; Muñoz et al., 1994]. Age constraints, surface and subsurface data, and stratigraphic differences demonstrate that the Mediano anticline is part of the Gavarnie thrust sheet in the footwall of the Peña Montañesa-Montsec thrust sheet [Fernández-Bellon, 2004; Fernández et al., 2012] (Figure 6).

[31] West of the Mediano anticline, the Olsón anticline has no evident expression at surface, as it is located below the Buil syncline (Figures 3 and 6). However, it has been imaged by seismic data and drilled by the Surpirenaica-1 well [Lanaja and Navarro, 1987]. The Olsón anticline is $10 \mathrm{~km}$ long and has an associated westward directed thrust in its central part (Figure 6). Seismic sections show growth 
geometries of the Middle Eocene slope to deltaic sediments located below the fluvial sediments cropping out in the core of the Buil syncline. Thus, it developed synchronously with the Mediano anticline, although it stopped growing earlier.

[32] The Añisclo anticline is the fold with the deepest level of exhumation in the study area, along with the Mediano anticline, and as a result, the Upper Cretaceous limestones crop out in its core (Figure 5). It occupies the same structural position east of the Boltaña anticline as the Olsón anticline. However, careful analysis of seismic profiles along with detailed structural analysis of the Añisclo anticline reveal that the Olsón anticline dies out to the north, under the Buil syncline, and so does the Añisclo anticline to the south (Figure 3). These folds are not connected as previously suggested by Soto and Casas [2001] [Fernández et al., 2012]. The Añisclo anticline is a fault propagation fold in its central part characterized by a vertical to steeply overturned frontal limb (Figure 5). The fold axis plunges southward at about $10^{\circ}$ increasing up to $25^{\circ}$ in its southernmost termination where the fold opens progressively and changes to a detachment anticline [Tavani et al., 2006]. This transition coincides with a sharp change of the dip of the forelimb from vertical to moderately dipping to the SW, and with a change of the fold axis trend from N-S to NWSE (Figure 3). See Tavani et al. [2006] for a detailed description of the Añisclo anticline and its related mesostructures. Growth strata are only preserved over the fold's southern termination. There, the oldest evident synfolding sediments are the lower Lutetian turbidites of the Ainsa system [Arbués et al., 2007]. Thus, the Añisclo anticline grew synchronously with the Mediano anticline. However, and based on the 3-D reconstruction of distinct surfaces of the Ainsa Basin, an initial development of the Añisclo anticline during the sedimentation of the upper part of the GerbéBanastón turbidite system (Figure 4) cannot be ruled out [Fernández et al., 2012].

[33] The Boltaña anticline is the most prominent anticline of the Sobrarbe system (Figures 2 and 3). It has been traditionally considered the boundary between the Jaca and Ainsa Basins as it marks an outcrop discontinuity of the lower and middle Eocene slope sediments [Mutti et al., 1988]. This fold is related to the propagation of the westward verging Boltaña blind thrust (Figures 5 and 6). The Boltaña anticline is over $25 \mathrm{~km}$ long and presents a very constant $\mathrm{N}-\mathrm{S}$ trend with practically no plunge. However, at its northern termination, it changes to a NW-SE trend where the anticline opens and splits into a system of smaller NW-SE trending folds (Figures 2 and 3). These folds are located in the hanging wall of a thrust splay of the Gavarnie thrust that represents the continuation of the Boltaña thrust (Figure 2) [Fernández et al., 2012]. This thrust system is located below the Monte Perdido thrust system and does not branch with it [Millán et al., 2006], contrary to its interpretation as the floor and frontal thrust of the Monte Perdido fold and thrust system [Séguret, 1972; Lacroix et al., 2011]. Toward the south, the Boltaña anticline ends south of the study area where it is relayed by the Balces anticline [Millán, 1996] (Figures 2 and 3). This anticline shows a prominent curved axial surface, describing an arc of about $45^{\circ}$ (southwestward convex) in map view [Rodríguez-Pintó et al., 2013] (Figure 2).

[34] The age of growth of the Boltaña anticline is constrained by the geometry and sedimentological characteristics of the syntectonic sediments. In the western forelimb of the Boltaña anticline, along the Ara River Valley, a thick succession from the lower Eocene slope sediments of the San Vicente Fm. to the upper Eocene continental deposits of the Campodarbe Group shows an apparently continuous growth wedge geometry in map view (Figure 7). Such map pattern was initially considered to reflect the growth of the anticline [Puigdefàbregas, 1975]. However, detailed mapping of this area reveals an unconformity in the Lutetian slope succession which separates the growth strata from the prefolding sediments (Figure 7). Below this unconformity, the lower Lutetian beds of turbidites and marls unconformably overlie and onlap the Lower Eocene platform beds of the Santa Marina Fm. The intersection lines between the slope and the platform beds (onlap lines) are subvertical to steeply plunging to the north and are subparallel to the northern edge of the Eocene foreland platform and to the strike of the gravitational collapse surfaces described by Barnolas and Teixell [1994] that truncate the underlying platform (Figure 7b). This relationship indicates that sediments below the unconformity were deposited on a northward tilted carbonate platform (Santa Marina Fm.) and that fanning of beds records the tilting of the foreland platform. On the contrary, above the unconformity, the onlap lines of the middle Lutetian to Bartonian growth strata are moderately dipping to the south (Figure 7b) and subparallel to the fold axis, as can be expected for growth strata. Paleocurrent directions in the preunconformity slope sediments on both limbs of the Boltaña anticline are at present directed to the NW (when unfolded) and would be parallel or slightly oblique to the onlap lines but at a high angle to the axis of the Boltaña anticline. These sedimentological and structural data confirm that lower Lutetian slope sediments deposited before the onset of growth of the Boltaña anticline. Conversely, paleocurrent directions of the middle Lutetian turbidites at the bottom of the growth sequence are subparallel to the axis of the anticline. In the eastern backlimb of the Boltaña anticline, where the moderate dip of bedding hampers the discrimination of the growth strata, a change of the turbidite paleoflow directions from NW-SE (oblique to and across the fold) during the sedimentation of the upper Ypresian-lower Lutetian turbidite systems of the Ainsa Basin (Gerbé-Banastón, Ainsa, Morillo, and Sieste) to N-S (parallel to the fold) during deposition of middle Eocene systems (Gabardilla, Guaso) has also been observed [Arbués et al., 2011]. Correlation of the Gabardilla system with the magnetostratigraphic succession of Mochales et al. [2012a] yields an age of approximately $42.5 \mathrm{Ma}$ for this system. In conjunction with the above described geometrical features of the growth strata, unconformities, paleocurrent directions, and recent magnetostratigraphic data, onset of growth of the Boltaña anticline can be dated as middle Lutetian. This age is also consistent with the middle Lutetian folding event described in the western limb of the Balces anticline, based on the unconformity observed in the Lutetian Guara limestones (Figure 4) [Millán et al., 2000; Barnolas and Gil-Peña, 2001]. The end of formation of the Boltaña anticline took place before the deposition of the lower part of the Campodarbe Fm. during early Priabonian times [Puigdefàbregas, 1975; Montes, 1992; Barnolas and Gil-Peña, 2001]. This age attribution challenges the role of the anticline as a paleogeographical barrier during the deposition of the upper Ypresian to 


\section{MUÑOZ ET AL.: PALEOMAGNETISM IN S PYRENEES}
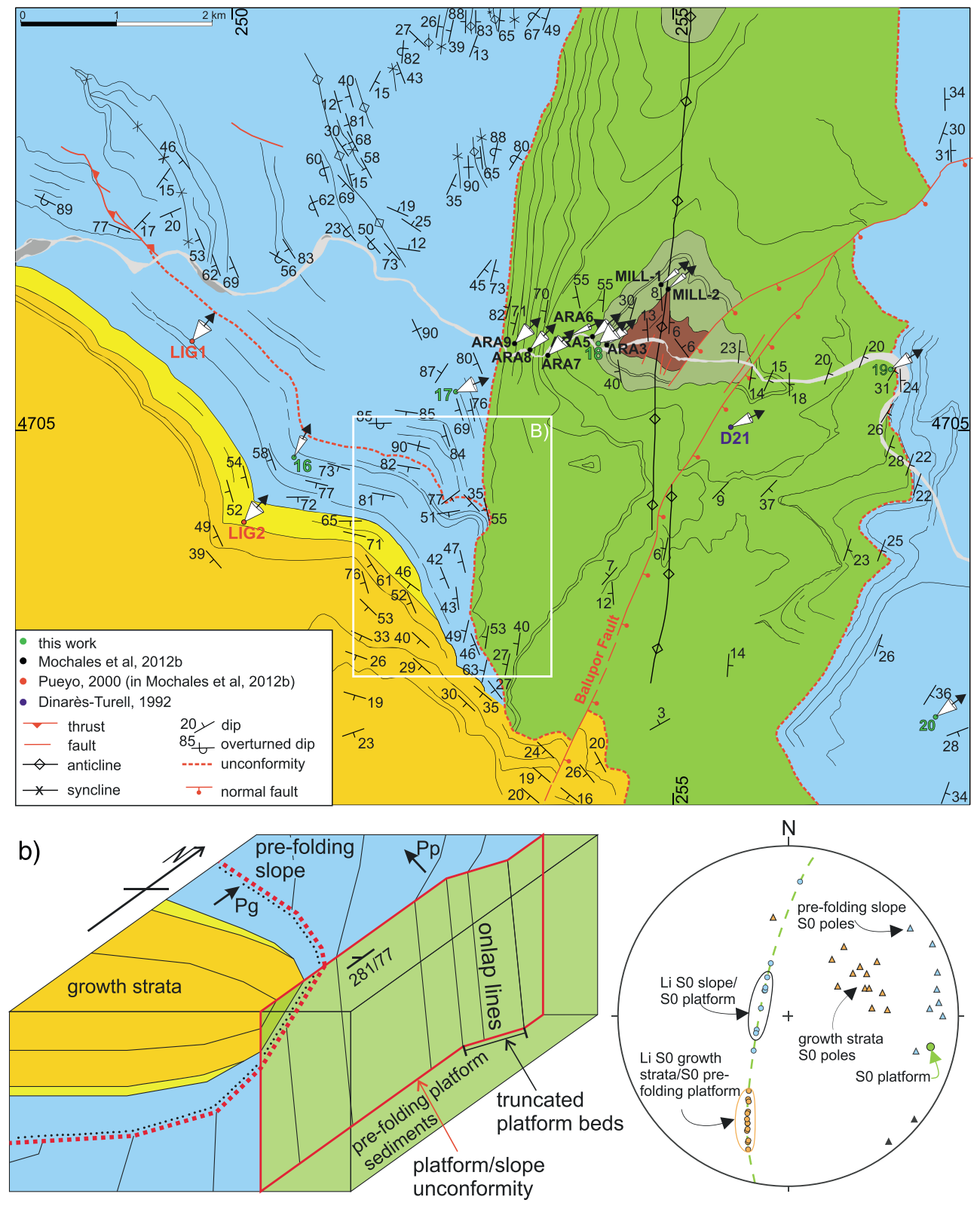

Figure 7. Detailed map of the Boltaña anticline and paleomagnetic data in this area from this and previous studies (see Table S1 in supporting information). White square indicates the position of the 3-D block diagram (b) which shows in detail the unconformity between the prefolding platform and slope sediments and the growth strata. Pp, paleocurrent directions of the prefolding slope; Pg, paleocurrent directions of the growth strata. The stereogram represents the poles of bedding of the prefolding platform and the prefolding slope sediments, and the poles of bedding of the growth strata. The intersection lineations between the slope and the platform bedding and between the growth strata and the prefolding platform are also included.

middle Lutetian San Vicente Fm. as previously suggested [Puigdefàbregas, 1975; Mutti et al., 1985, 1988].

\subsection{The La Fueba Thrust System}

[35] Thrusts and related folds of the La Fueba thrust system are located east of the Mediano anticline, in the footwall of the Peña Montañesa-Montsec thrust sheet. The La Fueba system, also called Arro system by some authors [Barnolas et al., 1991; Martínez Peña, 1991; Casas et al., 2002], consists of a set of NW-SE to N-S trending structures, verging toward the SW and parallel to the main Peña Montañesa-Montsec thrust to which they are connected (Figures 2, 3, 5, 6, and 8) [Muñoz et al., 1994]. The structure of this system has been described by many authors [Nijman and Nio, 1975; Mutti et al., 1988; Barnolas et al., 1991; Martínez-Peña, 1991; Travé et al., 1997, 1998; Barnolas and Gil-Peña, 2001; Casas et al., 2002; Fernández et al., 2012], the most prominent structures being the L'Atiart and Los Molinos thrusts and their related hanging wall anticlines and footwall synclines (Figure 8).

[36] The L'Atiart thrust is the most relevant structure of this system with several kilometers of displacement as it is the oblique ramp connecting the Montsec and Peña 


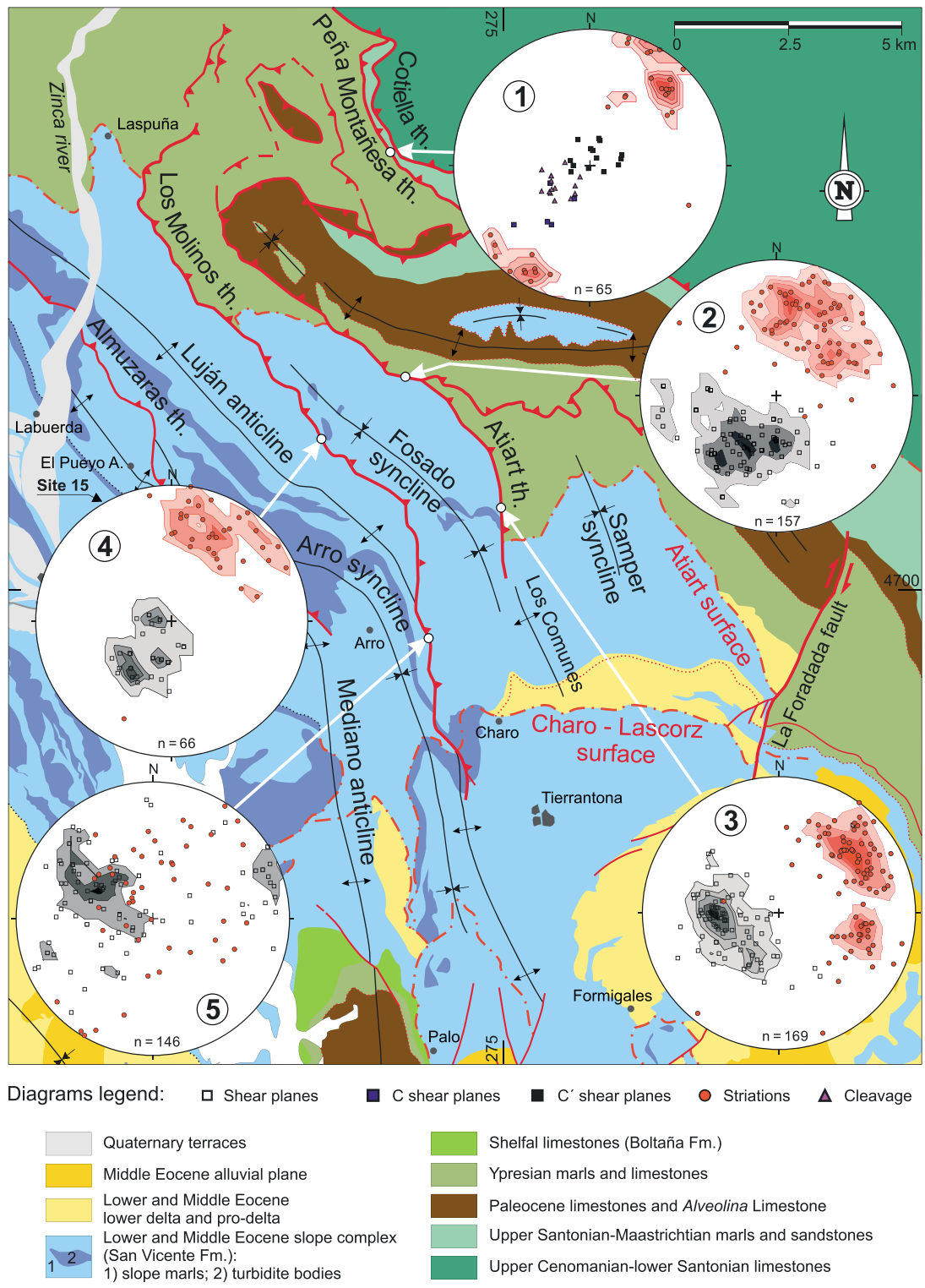

Figure 8. Detailed map and kinematic data of the main thrusts in the La Fueba fold and thrust system.

Montañesa thrusts [Soler and Garrido Megías, 1970; Nijman and Nio, 1975; Farrell et al., 1987; Fernández et al., 2012]. The other thrusts scarcely accumulate $2 \mathrm{~km}$ of total displacement [Barnolas et al., 1991].

[37] Thrusts and related folds of the La Fueba system show a change of trend from NW-SE in the north to $\mathrm{N}-\mathrm{S}$ in the south, similar to that of the Mediano anticline (Figure 8). The same change of trend along the structural bend is also observed in the mesostructures related with the thrusts. Thrusts in the La Fueba system have fault zones that are meter-thick shear zones characterized by strongly foliated sediments and an S-C-C'-type shear fabric [Travé et al., 1997; Lacroix et al., 2011]. In the NW area, where thrusts and folds have a NW-SE trend, shear planes mostly strike parallel to the trend of the main thrusts and most of the striations on the calcite veins located along the shear planes are dip slip (diagram 1 in Figure 8). As the strike of thrusts changes, the amount of trend or pitch dispersal of shear planes and striations increases and is proportional to the deviation of thrust strike from the regional WNW-ESE trend (compare data of the L'Atiart thrust along the bend from NW to SE; diagrams 1, 2, and 3 of Figure 8): striations indicate almost pure dip-slip motion in NW-SE striking thrusts, but range from dip slip to strike slip for $\mathrm{N}-\mathrm{S}$ trending thrusts, always transporting the hanging wall or eastern block to the SW. Often, more than one generation of striations with different pitch is superimposed in the same shear calcite veins. Chronological criteria between them are rare, but when visible, strike-slip striations (dextral) are younger than the reverse dip-slip ones, as also suggested by Travé et al. [1997, 1998]. In general, shear zones and related striations show a more complicated pattern in the portions where thrusts trend $\mathrm{N}-\mathrm{S}$, suggesting fault reactivation in addition to rotation. This is particularly evident along the Los Molinos thrust (diagrams 4 and 5 in Figure 8). Moreover, in the structurally shallower parts of the thrusts, conjugate shears and minor thrusts and back thrusts coexist, resulting in more complicated diagrams (diagram 5 in Figure 8). 
[38] The age of the La Fueba thrust system is constrained by the preserved syntectonic sediments. It developed mostly during the late Ypresian (Cuisian) when deep water emergent thrusts controlled the transition from the deltaic sediments in the hanging wall to the slope sedimentary systems of the Ainsa Basin in the footwall (Figures 4 and 6). Thrusts mostly developed in a piggyback sequence. Each major thrust has a related major unconformity or truncation surface, which developed by gravitational extensional collapse or successive gravitational failures of the rising hanging wall [Muñoz et al., 1994]. The most significant and preserved pairs of surfaces are the L'Atiart thrust-L'Atiart truncation surface and Los Molinos thrust-Charo-Lascorz truncation surface (Figure 8) [Soler-Sampere and Garrido, 1970; Mutti et al., 1988; Muñoz et al., 1994]. The first one is early-middle Cuisian in age and the second one is latest Cuisian (Figure 4). Unconformities have also been slightly deformed, either during the displacement on the lower and younger thrusts of the La Fueba system or during subsequent reactivation of the main thrust planes.

[39] Structures of the La Fueba thrust system have the same structural position and probably the same age as (or slightly older than) the Monte Perdido thrust and related folds, which deform the Cretaceous to Paleogene succession of the Gavarnie thrust sheet (Figures 2 and 3). The frontal part of the Monte Perdido fold and thrust system deforms the Cuisian turbidites in the footwall of the La Peña Montañesa thrust sheet at its westernmost outcrop in the Castillo Mayor klippe (Figure 3).

\subsection{Mesoscopic Structures: Cleavage, Fracture, Fault, and Vein Networks}

[40] The Gavarnie thrust sheet in the Ainsa Fold and thrust oblique zone displays systematic suites of mesoscopic structures that accommodated internal strain, including spaced cleavage, fracture and vein networks, minor folds, and minor faults [Holl and Anastasio, 1995a; Tavani et al., 2006, 2012].

[41] A regional pressure solution cleavage is observed in the Mesozoic-Paleogene sediments at the northern exposures of the Gavarnie thrust sheet of the study area [Choukroune and Séguret, 1973]. Cleavage is axial planar to regional and mesoscale folds and parallels the strike of the fold and thrust structures of the Gavarnie thrust sheet. As a result, attitude of the cleavage planes shows the same map pattern as the above described thrusts and folds and emphasizes the change of the structural trend from WNW-ESE to N-S at the NW corner of the Ainsa Oblique Zone (Figures 2 and 3). The cleavage intensity decreases southward to form a cleavage front as described by many authors [Séguret, 1972; Choukroune, 1976; Holl and Anastasio, 1995a; Oliva-Urcia et al., 2008]. However, such cleavage front is not a sharp feature, as the occurrence of the cleavage depends also on the mechanical stratigraphy and the structural position with respect to the folds affecting the Gavarnie thrust sheet [Holl and Anastasio, 1995a; Tavani et al., 2006]. Cleavage changes from pervasively distributed in the northern areas to more localized in higher structural levels to the south. This transition is obvious in the Boltaña and Añisclo anticlines. Thus, in the northern part of these folds, where they trend NW-SE, cleavage is pervasive and penetrative all around the fold, regardless of both anticlines being open. Southward, where the folds change their trend to $\mathrm{N}-\mathrm{S}$ into the oblique zone and they become significantly tighter, cleavage is more localized and mainly restricted to the vertical to overturned forelimb [Tavani et al., 2006]. Such internal strain gradient also occurs in an $\mathrm{E}-\mathrm{W}$ direction. Thus, in the forelimb of the Añisclo anticline, at the central part, pressure solution cleavage is closely spaced, and locally, up to three different sets of cleavage planes are observed (normal, oblique, and parallel to bedding) [Tavani et al., 2006]. In the same transect (Figure 5), the forelimb of the Boltaña anticline only shows a family of spaced layer normal pressure solution cleavage at high angles to bedding [Tavani et al., 2012]. The Mediano anticline is located southward of the cleavage front as well as is the southern part of the Boltaña anticline [Holl and Anastasio, 1995b].

[42] Pressure solution cleavage is parallel to the fold axis, remaining subperpendicular to bedding in fold limbs and hinge zones, and evenly spaced throughout. Such bedding/ cleavage relationships are only overprinted by selective cleavage infilling in the vertical to overturned forelimb of fault-related folds. These angular and spacing relationships indicate that pressure solution cleavage formed before and at the initial stages of deformation by layer parallel shortening and was subsequently tilted along with bedding during large-scale folding and thrusting. Locally, it continued to develop during fold tightening [Tavani et al., 2006]. Layer parallel shortening directions give the orientation of finite and instantaneous shortening axes. These directions are roughly perpendicular to the structural trend around the Ainsa Oblique Zone and are consistent with the shortening directions inferred from mechanically twinned calcite grains and minor faults [Holl and Anastasio, 1995b]. Holl and Anastasio [1995a] estimated that the amount of layer parallel shortening increases from $<5 \%, 2 \mathrm{~km}$ forward of the cleavage front, to $\sim 30 \% 7 \mathrm{~km}$ hindward of the cleavage front, and then remains constant further hindward.

[43] Fracture and veins show a systematic symmetry with respect to large-scale folds. The most common fracture and vein systems are those parallel (longitudinal) and perpendicular (transversal) to the fold axis. Transversal joints and veins are the predominant fracture system in the Añisclo anticline [Tavani et al., 2006]. In the Boltaña anticline, apart from the transversal joints and veins, the main fracture system corresponds to longitudinal extensional faults. These faults were the result of E-W stretching, parallel to the shortening direction, and developed before and synchronously with folding [Tavani et al., 2012]. Extensional fracture assemblages predominate in the central and southern parts of the Boltaña anticline. In these areas, the major mesoscale record of the E-W oriented layer parallel shortening, perpendicular to the fold trend, is provided by AMS data [Mochales et al., 2010] as the mesostructural pattern that only rarely includes contractional structures. Changes of both direction and shape of the AMS ellipsoid record the increasing amount of deformation from the southern parts of the Ainsa Oblique Zone to the northern parts where cleavage is well developed [Dinarès-Turell and Parés, 1992; Parés and DinarèsTurell, 1993].

[44] In the northern parts of the Boltaña anticline, conjugated strike-slip faults, tilted along with bedding during folding, are part of the contractional assemblage together with pressure solution cleavage [Tavani et al., 2012]. In the Añisclo anticline, tilted strike-slip faults have also been observed [Tavani et al., 2006]. 
[45] Field observations of mutually crosscutting relationships between the main pressure solution cleavage set, strike slip and extensional faults, and joints/veins support the interpretation that they developed coevally.

\subsection{Macroscopic Structures: Extensional Faults}

[46] The youngest structures observed in the Ainsa Oblique Zone correspond to NE-SW trending extensional faults described as the Balupor-San Marzial fault system by Fernández-Bellon [2004]. They have a variable trend from $\mathrm{N}-\mathrm{S}$ to E-W (Figures 2 and 3). Among them, the most prominent one is the San Marzial fault which has a curvilinear map pattern and a throw of about $1 \mathrm{~km}$ [Ríos Aragüés et al., 1982a, 1982b]. It cuts the Cotiella-Peña Montañesa thrust sheets and the Gavarnie thrust sheet below, but it does not displace the Gavarnie thrust (Figure 3). Extensional faults of this system obliquely truncate the Boltaña and Añisclo anticlines and are associated with extensive Triassic outcrops along the NW of the Cotiella thrust sheet. In cross section, they appear as extensional collapse features of the anticlines as they partially reactivate their related thrusts at depth (Figure 5). These extensional faults control along-strike changes in the geometry of the Boltaña and Añisclo anticlines, suggesting some synchronicity with fold growth [Fernández et al., 2012], and are known to be active at least until Priabonian times as they offset sediments of the late Eocene Campodarbe Group (Figure 7).

[47] The extensional faults that define the southern boundary of the Mediano anticline (Clamosa faults) [Teixell and Barnolas, 1995] are similar in nature to the Balupor-San Marzial system in that they both are interpreted to be contained entirely within the Gavarnie thrust sheet, they are active at least until the Oligocene (as evidenced by their cutting relationships with sediments of that age), they crosscut the entirety of a major anticline (the Mediano anticline), and they are related to major outcrops of Triassic shales and evaporites (Figure 3). Furthermore, the Balupor-San Marzial and the Clamosa faults are located where the N-S trend of the Ainsa oblique structures swings to a NW-SE trend to the north (Balupor-San Marzial) and to the south (Clamosa). These coincidences are strong indications for a common origin for both systems of extensional faults.

\section{Paleomagnetism in the Ainsa Basin}

\subsection{Previous Paleomagnetic Studies}

[48] Several paleomagnetic studies have revealed important clockwise $(\mathrm{CW})$ vertical axis rotations in the sediments of the Ainsa Basin [Dinarès-Turell, 1992; Fernández-Bellon, 2004; Mochales, 2011; Mochales et al., 2012a, 2012b]. DinarèsTurell [1992] reported significant vertical axis rotations (up to $60^{\circ}$ ) in the Ilerdian and Cuisian platform sediments in the Boltaña and Mediano anticlines. This rotation decreases to $40^{\circ}$ in the middle Lutetian sediments of the Sobrarbe Fm. Mochales et al. [2012b], in a detailed study of the vertical axis rotations experienced by the Boltaña anticline combined with the magnetostratigraphy of a complete succession of the Ainsa Basin [Mochales et al., 2012a], reported a CW rotation which decreases from $52^{\circ}$ in the Lower Eocene sediments of the core of the anticline to a few degrees in the Upper Eocene sediments in its eastern limb. Upper Lutetian sediments sampled in a magnetostratigraphic study by Bentham [1992] in the western limb of the Mediano anticline revealed around $30^{\circ}$ of $\mathrm{CW}$ rotation. This regional $\mathrm{CW}$ rotation pattern is in concurrence with the up to $40^{\circ}$ of $\mathrm{CW}$ rotation documented by Pueyo et al. [1997], Pueyo [2000], and Pueyo et al. [2002, 2003a] in Bartonian to Chattian materials west of the Ainsa Basin, along the south Pyrenean thrust front of the Sierras Exteriores (Figure 2). Data from the magnetostratigraphic studies by Hogan [1993] in younger sediments of the Jaca Basin and by Pueyo [2000], Oms et al. [2003], and Pueyo et al. [2003b] along the Jaca-Boltaña transect show around $30^{\circ}$ of $\mathrm{CW}$ rotations. However, vertical axis rotations measured east of the Ainsa Basin in Eocene sediments of the Tremp-Graus Basin are mostly smaller than $20^{\circ}$ [Dinarès-Turell, 1992; Dinarès et al., 1992; Beamud et al., 2003] (Figure 2). This fact, combined with evidence of counterclockwise (CCW) vertical axis rotation on the eastern oblique thrust zone of the Montsec unit [Dinarès-Turell, 1992; Dinarès et al., 1992; Sussman et al., 2004] led Dinarès et al. [1992], Muñoz [1992], and Vergés [1993] to consider that deformation in the central part of the Montsec thrust occurred by plane strain, validating the restoration of the ECORS-Pyrenees cross section [Beaumont et al., 2000].

[49] A recent compilation of paleomagnetic data in PermianTriassic red beds of the central western Pyrenees has reported no significant vertical axis rotation of the sites located in the footwall of the Gavarnie thrust sheet in the study area [Oliva-Urcia et al., 2012b]. The same authors describe a slight $\mathrm{CW}$ vertical axis rotation of $8^{\circ}-10^{\circ}$ for the Upper Cretaceous paleomagnetic component in the Sierras Interiores (Gavarnie thrust sheet west of the study area) and an average $\mathrm{CW}$ vertical axis rotation of $14^{\circ}$ for the remagnetized component in the Cretaceous and Paleogene rocks of the Monte Perdido thrust system (Figure 2) [Oliva-Urcia and Pueyo, 2007b; OlivaUrcia et al., 2012b].

[50] Regardless the significant amount of available paleomagnetic data [López et al., 2008], all these paleomagnetic studies have yielded varying interpretations. Some of the inconsistencies between interpretations arise from the irregular density of sampling and the natural scattering of data but also derive from the lack of integration with structural and stratigraphic data.

\subsection{Paleomagnetic Sampling and Laboratory Procedures}

[51] Our study has focused on complementing previous paleomagnetic works in the Ainsa Basin. Sampling was designed to optimize the distribution of sites in previously nonsampled structures like the Mediano anticline and to delineate rotation patterns along the strike of folds and across their associated growth sediments.

[52] Thirty-six sites were sampled in order to characterize the distribution of vertical axis rotations within the Ainsa Fold and thrust oblique zone (Figure 3). Sampling was carried out by gathering between 8 and 11 cores per site. To average the Earth's magnetic field, cores were sampled along 5 to $10 \mathrm{~m}$ of stratigraphic profile. Samples were obtained with a portable gasoline power drill and were oriented in situ with a compass mounted on an orienting device with inclinometer. Sampling focused on limestones, marls, marly limestones, and fine-grained sandstones from middle Ilerdian to upper Lutetian stratigraphic units. Analyses were carried out in the Paleomagnetic Laboratory of Barcelona. They consisted of stepwise thermal demagnetization with demagnetizers TSD-1 


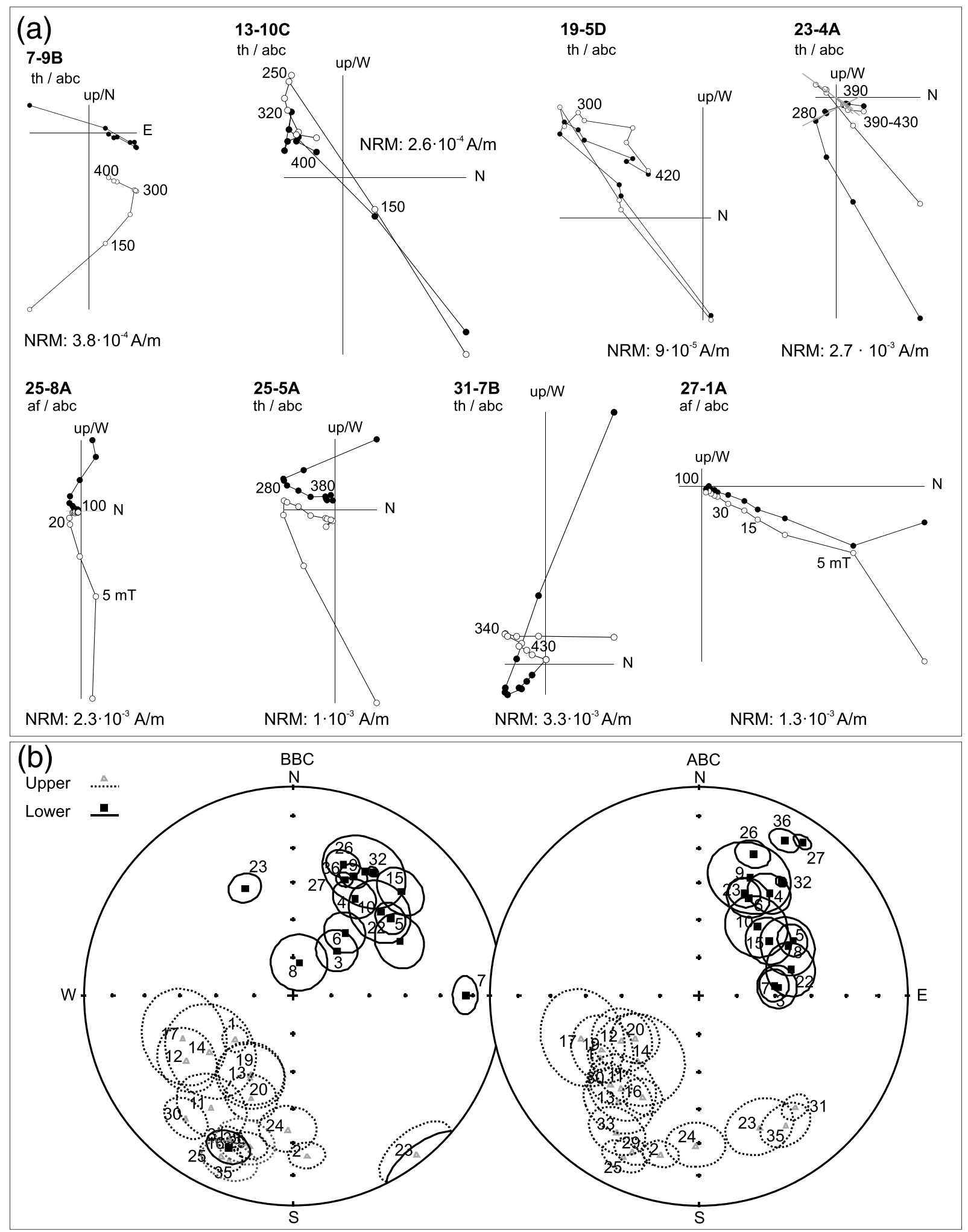

Figure 9. (a) Zijderveld demagnetization diagrams of representative samples. Open (solid) symbols represent projection onto the vertical (horizontal) planes. All diagrams are represented after bedding correction $(\mathrm{abc})$. $\mathrm{AF}$, alternating field demagnetization, units are $\mathrm{mT}$; $\mathrm{TH}$, thermal demagnetization, units are ${ }^{\circ} \mathrm{C}$. Grey lines in sample 23-4A represent the characteristic components calculated: an intermediate temperature component between $280^{\circ} \mathrm{C}$ and $390^{\circ} \mathrm{C}$ of reversed polarity and a high temperature component of normal polarity, defined between $390^{\circ} \mathrm{C}$ and $430^{\circ} \mathrm{C}$. (b) Stereographic projection of the mean directions and obtained $\alpha_{95}$ at site level before (BBC) and after (ABC) bedding correction. Projections are on upper (grey color, dashed lines) and lower hemisphere (black color, solid lines). 
(Schonstedt) and MMTD-80 (Magnetic Measurements) at steps of $20^{\circ}$ and $30^{\circ}$ up to $500^{\circ} \mathrm{C}$. Stepwise alternating field demagnetization was also conducted with a GSD-5 (Schonstedt) up to $100 \mathrm{mT}$ with no apparent improvement in the quality of the demagnetization trajectories. Subsequent measurement of the natural remanent magnetization (NRM) after each demagnetization step was carried out in superconducting rock magnetometers (SRM755R by $2 \mathrm{G}$ Enterprises and GM400 by Cryogenic Consultants). Intensity of initial NRM of samples is in the range $9 \cdot 10^{-5}$ to $3 \cdot 10^{-3} \mathrm{~A} / \mathrm{m}$. Demagnetization diagrams of representative samples are represented in Figure 9a. In most of the samples, a low temperature component is observed, which remains stable up to $250-300^{\circ} \mathrm{C}$ or $15 \mathrm{mT}$ and which is mainly parallel to the present day magnetic field in geographic (in situ) coordinates. This component will not be taken into account for further calculations. The characteristic component of each sample was calculated by best fit method after visual inspection of the demagnetization diagrams using the Paldir software developed by the Utrecht Paleomagnetic Laboratory. This component is generally well defined between $300^{\circ} \mathrm{C}$ and $400^{\circ} \mathrm{C}$ or 15 and $50 \mathrm{mT}$, pointing to (titano)magnetite as the main remanence carrier. However, this is most probably not the only magnetic carrier. Rock magnetism analyses in previous studies have revealed the presence of iron sulfides and high coercivity minerals together with magnetite in the limestones of the Boltaña, Yeba, and Metils Fms. and in the Alveolina Limestone [Mochales et al., 2012a]. The calculated characteristic components of each site were corrected for bedding dip with two different approaches (Table 1). The directions for sites far from the more prominent folds were corrected by rotating bedding to horizontal along the bedding strike line. On the other hand, directions measured on the Boltaña, Añisclo, and Mediano anticlines were restored by taking the fold geometry into account. The dense dip data set recorded in the area, with up to 5000 readings of bedding attitudes, was used to calculate the geometric elements of the main folds or parts of major folds for each site or group of sites. Rotation of the measured magnetic declinations were performed taking into account the fold axis of the best cylindrical fit geometry as well as the best conical fit in some of the folds in order to avoid spurious rotation results [Pueyo et al., 2003a]. Rotations were done using a code written for the Orient program by H. Charlesworth [Charlesworth et al., 1989]. This procedure only yielded significantly different results for the Mediano anticline, for which directions were restored according to the conical geometry of the fold (Table 1).

[53] Mean directions were calculated for each site from the single characteristic components (Figure $9 \mathrm{~b}$ and Table 1) and then compared with the reference Eocene direction for stable Iberia [Taberner et al., 1999] to obtain a measure of the vertical axis rotation at each site with its associated uncertainty [Demarest, 1983]. The reference direction was recalculated for the Ainsa coordinates with the via pole conversion method [Noel and Batt, 1990] getting a direction of 004/52.

\section{Results of Paleomagnetic Data}

\subsection{Stability of the Magnetization}

[54] In order to verify the primary character of magnetization, fold tests [McFadden, 1990] and direction/correction tilt tests [Enkin, 2003] were performed on the Boltaña (sites 16,
17, 18, 19, 20, 21, and 22), Añisclo (sites 30, 31, 34, and 35), and Mediano anticlines (sites 3, 4, 5, 7, 8, 9, and 10) and on an outcrop-scale anticline in the footwall of the Almuzaras thrust, south of El Pueyo de Araguás (site 15) (Figures 3, 8, and 10). Positive fold and direction/correction tilt tests with a statistical best grouping around $100 \%$ of unfolding were obtained in site 15 and in the Boltaña and Mediano anticlines, pointing to a prefolding origin of the magnetization, as previously documented by numerous studies in the region [Mochales et al., 2012a, 2012b; Rodríguez-Pintó et al., 2012]. Although in these positive fold tests paleomagnetic directions group after bedding correction, some scatter in trends remains. This dispersion obeys both inherent different qualities of the paleomagnetic signal and the syntectonic character of the sediments, with younger materials recording less amount of rotation, as evidenced in the Mediano anticline. In the forelimb of the Añisclo anticline, both negative fold and direction/correction tests were obtained with a best fit at $5 \%$ of unfolding and a greater dispersion for tectonic-corrected (100\% unfolding) magnetic vectors. Furthermore, tectoniccorrected directions from sites 31 and 35 indicate $\mathrm{CCW}$ rotations that would contradict the regional $\mathrm{CW}$ rotation pattern. The fold test is not significant for sites 30 and 34 as both sites show very small differences between in situ and tectonically corrected directions due to the low dip of bedding. However, the structural position of site 34 within the cleavage domain and the fact that sites 31 and 35 within the same fold yield a negative fold test lead us to interpret site 34 as remagnetized. Unfortunately, there are no arguments to establish the primary or secondary origin of magnetization of site 30 . Therefore, sites 31, 34, and 35 (and maybe 30) are assumed to have been remagnetized after bed tilting but prior to the end of the regional rotation and record a minimum value of rotation in this sector. Their remagnetization is interpreted to be related to their location in the more deformed forelimb of the Añisclo anticline where cleavage is well developed.

[55] In the northern sector of the study area, sites 23,24 , 25 , and 26 are placed within a cleavage domain marked by the presence of a penetrative pressure solution cleavage visible at outcrop scale (Figure 3). As previously said, Triassic, Cretaceous, and Eocene rocks within this domain are affected by a generalized reversed polarity remagnetization event [Oliva-Urcia and Pueyo, 2007b; Oliva-Urcia et al., 2008; Oliva-Urcia et al., 2012a] (red arrows in Figure 2). It should be noted that two components have been identified in site 23 (Figure 9a and Table 1): a "high temperature" component defined between $390^{\circ} \mathrm{C}$ and $430^{\circ} \mathrm{C}$ yielding normal polarity and assumed to represent a primary magnetization, and an "intermediate temperature" component defined between $280^{\circ}$ $\mathrm{C}$ and $390^{\circ} \mathrm{C}$ which always exhibits reversed polarity and which we interpret to be linked to the pressure solution remagnetization event reported by Oliva-Urcia et al. [2008]. Similarly, its neighboring site 26 also exhibits two components, including a reversed polarity intermediate temperature component defined between $250^{\circ} \mathrm{C}$ and $350^{\circ} \mathrm{C}$, although less well defined than in site 23 . It is worth noticing that the NRM intensity of these sites is strikingly high (in the range of $2-8 \cdot 10^{-3} \mathrm{~A} / \mathrm{m}$ ). Sites 24 and 25 only reveal one characteristic component of reversed polarity, for which primary or secondary origin is difficult to test as no fold test can be performed due to the constant and low dip of bedding. However, the high intensity of the NRM in these sites (in the 

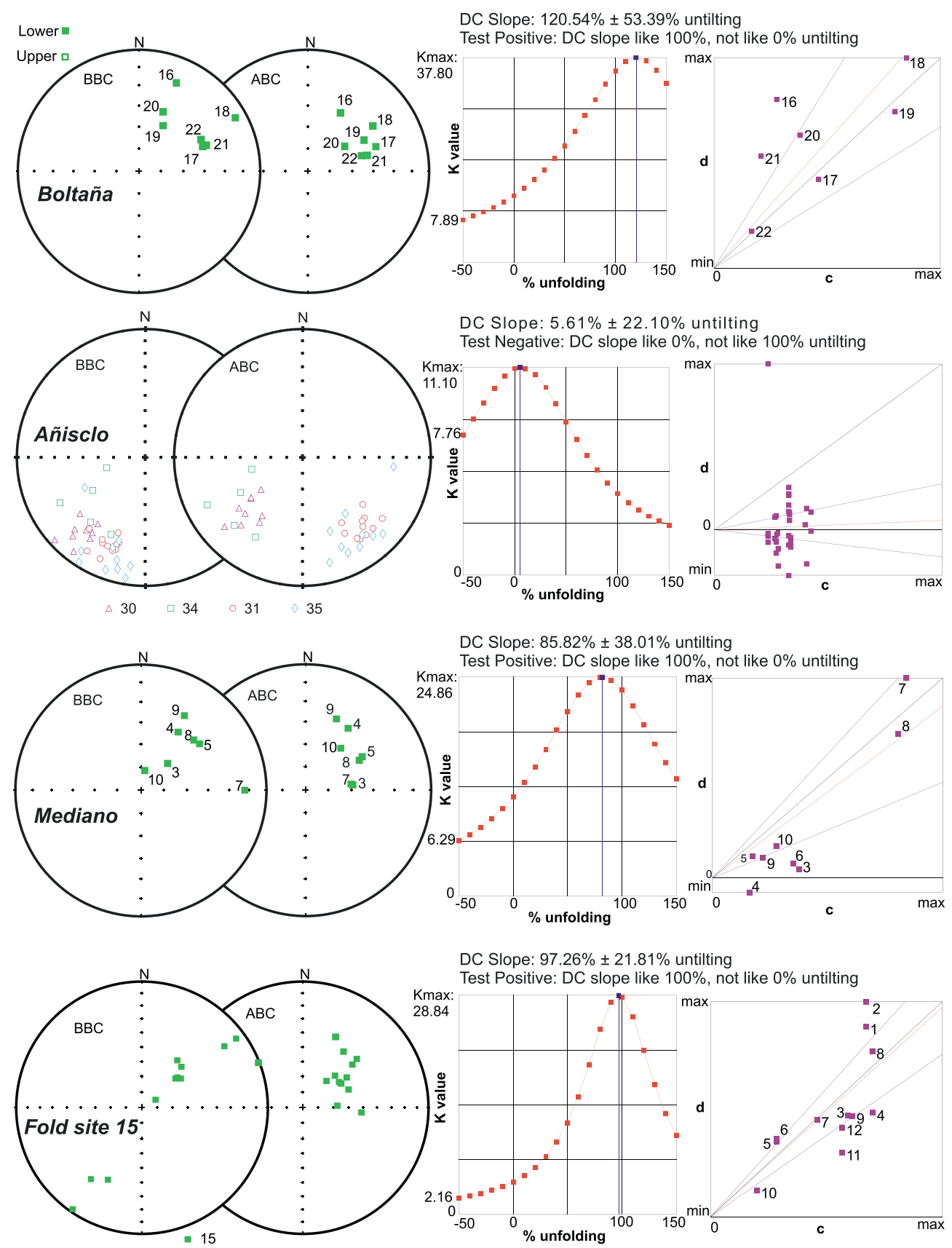

Figure 10. Results of the fold tests [McFadden, 1990] and the direction/correction tilt tests [Enkin, 2003] performed in the study area. Tests have been done in the Boltaña (sites 16 to 22), Añisclo (sites 30-31 and 34-35), and Mediano (sites 3 to 5 and 7 to 10) anticlines and in site 15, an outcrop scale anticline in the hanging wall of the Almuzaras thrust south of El Pueyo de Araguás. Open (solid) symbols represent projection on the upper (lower) hemisphere.

range of $3-4 \cdot 10^{-3} \mathrm{~A} / \mathrm{m}$ ), the constantly reversed polarity of the characteristic component, the low inclination of their tectonic corrected ChRMs, and their structural position within the cleavage domain make these sites as suspect of being remagnetized during the pressure solution remagnetization event. Furthermore, they record a remagnetized direction in continuation with the area described by Oliva-Urcia and Pueyo [2007a, 2007b] and Oliva-Urcia et al. [2008].

[56] Southward, sites 27, 32, and 36 are also located within the cleavage domain and exhibit high intensity NRMs and anomalously low inclinations. However, these sites yield normal polarity contradicting the observed reversed polarity for the remagnetized component [Oliva-Urcia et al., 2008]. Far from the cleavage domain, in the footwall of the Peña Montañesa thrust sheet, site 2 also shows an anomalously low inclination and an unrotated mean direction, which make it suspicious of being remagnetized.

\subsection{Vertical Axis Rotations in the Ainsa Fold and Thrust Oblique Zone}

[57] Restored values of the mean magnetic declinations in the 36 sites studied in this work (Table 1) together with the 
Table 1. Geographic, Stratigraphic, Structural, and Paleomagnetic Information of the Studied Sites ${ }^{\text {a }}$

\begin{tabular}{|c|c|c|c|c|c|c|c|c|c|c|c|c|c|}
\hline \multirow[b]{3}{*}{ Site } & & & \multirow{3}{*}{$\begin{array}{c}\text { Stratigraphy } \\
\frac{(2)}{\text { Stratigraphic Age }}\end{array}$} & & & \multirow{3}{*}{$\begin{array}{c}\text { Bedding } \\
\frac{(4)}{\text { dip dir/dip }}\end{array}$} & \multicolumn{7}{|c|}{ Magnetic Components } \\
\hline & \multicolumn{2}{|c|}{$\begin{array}{l}\text { Location } \\
\text { (1) }\end{array}$} & & \multicolumn{2}{|c|}{$\begin{array}{l}\text { Structure } \\
\text { (3) }\end{array}$} & & \multicolumn{4}{|c|}{ In situ (geograph. coord.) } & \multicolumn{3}{|c|}{$\begin{array}{l}\text { Bed. Corr. } \\
\text { (6) }\end{array}$} \\
\hline & Long & Lat & & Structure & Trend/plunge & & $\mathrm{N}$ & $\mathrm{D} \& \mathrm{I}(\mathrm{bbc})$ & $\alpha 95$ & K & corr1 & $\mathrm{D}(\mathrm{abc})$ & corr2 \\
\hline 1 (MM1) & 271670 & 4695020 & Middle Cuisian & & & $003 / 18$ & 8 & $233 /-61.7$ & 5.2 & 113.8 & & & \\
\hline 2 (HM1) & 274350 & 4698290 & Middle Cuisian & & & $090 / 32$ & 7 & $174.9 /-24$ & 6.2 & 94.8 & cyl & 189.2 & $\mathrm{bc}$ \\
\hline 3 (FM1) & 272800 & 4690350 & Lower Lutetian & Mediano anticline & & $138 / 21$ & 7 & $44.5 / 65.4$ & 12.6 & 23.8 & cyl & 84.4 & $\mathrm{bc}$ \\
\hline 4 (FM2) & 273030 & 4690520 & Lower Lutetian & Mediano anticline & & $003 / 05$ & 7 & $32.5 / 44$ & 7.8 & 60.2 & & & \\
\hline 5 (FM3) & 273040 & 4690520 & Lower Lutetian & Mediano anticline & & $185 / 11$ & 8 & $51.7 / 40$ & 5.6 & 97.8 & cyl & 59.6 & $\mathrm{bc}$ \\
\hline 6 (FM4) & 277560 & 4689660 & $\begin{array}{c}\text { Lower - } \\
\text { Middle Lutetian }\end{array}$ & & & $355 / 15$ & 8 & $39.6 / 57.8$ & 7.8 & 51.5 & & & \\
\hline 7 (YM1) & 270700 & 4689190 & Upper Ilerdian & Mediano anticline & & $278 / 42$ & 10 & $89.9 / 18.3$ & 8.9 & 38.4 & & & \\
\hline 8 (YM2) & 272400 & 4690650 & Upper Ilerdian & Mediano anticline & & $080 / 34$ & 8 & $11.1 / 76.8$ & 12 & 22.4 & & & \\
\hline 9 (SM1) & 267530 & 4688130 & Middle Lutetian & Mediano anticline & & $264 / 12$ & 6 & $30.1 / 31.5$ & 15.2 & 20.3 & cyl & 23.1 & $\mathrm{bc}$ \\
\hline 10 (PM1) & 269100 & 4687090 & Middle Lutetian & Mediano anticline & & $248 / 14$ & 7 & $46.2 / 41.4$ & 9.6 & 40.7 & cyl & 39.7 & $\mathrm{bc}$ \\
\hline 11 (EM1) & 268630 & 4684920 & Upper Lutetian & Mediano anticline & & $186 / 09$ & 7 & $216.1 /-34.1$ & 12.6 & 23.8 & cyl & 219.9 & $\mathrm{bc}$ \\
\hline 12 (AP1) & 266540 & 4698290 & Middle Cuisian & Mediano anticline & & $234 / 15$ & 6 & $238.6 /-40.1$ & 11.5 & 34.9 & cyl & 240.2 & $\mathrm{bc}$ \\
\hline 13 (AP2) & 267580 & 4705000 & Middle Cuisian & & & $061 / 20$ & 7 & $207.6 /-53.8$ & 10.7 & 74.7 & & & \\
\hline 14 (OA1) & 272090 & 4705040 & $\begin{array}{l}\text { Lower - Middle } \\
\text { Cuisian }\end{array}$ & & & $193 / 11$ & 5 & $235.8 /-50.2$ & 17.3 & 20.5 & & & \\
\hline 15 (BA1) & 266600 & 4701670 & $\begin{array}{l}\text { Upper Cuisian } \\
\text { - Lower Lutetian }\end{array}$ & & & $213 / 27$ & 12 & $46 / 23.4$ & & 4.4 & cyl & 52.8 & $\mathrm{bc}$ \\
\hline $16(\mathrm{AB})$ & 251535 & 4704356 & Lower Lutetian & Boltaña anticline & $185 / 0$ & $171 / 82$ & 8 & $203 / 22$ & 7.5 & 55.1 & & & \\
\hline 17 (JB) & 253031 & 4705874 & Lower Lutetian & Boltaña anticline & $185 / 0$ & $258 / 85$ & 6 & $249 /-43$ & 16.9 & 16.6 & & & \\
\hline 18 (YB) & 254488 & 4706261 & Upper Ilerdian & Boltaña anticline & $185 / 0$ & $269 / 54$ & 8 & $241 / 10$ & 22.4 & 7 & & & \\
\hline 19 (BB) & 257560 & 4705951 & Upper Cuisian & Boltaña anticline & $185 / 0$ & $121 / 31$ & 6 & $208 /-55$ & 10.6 & 40.8 & & & \\
\hline $20(\mathrm{CB})$ & 258408 & 4701832 & Lower Lutetian & Buil syncline & $185 / 0$ & $159 / 69$ & 7 & $202 /-46$ & 9.4 & 42.3 & & & \\
\hline 21 (SB) & 260560 & 4700852 & Lower Lutetian & Buil syncline & $185 / 0$ & $222 / 12$ & 7 & $069 / 40$ & 22 & 9.5 & & & \\
\hline 22 (GB) & 260682 & 4700467 & Lower Lutetian & Buil syncline & $185 / 0$ & $203 / 19$ & 9 & $063 / 42$ & 9.3 & 31.5 & & & \\
\hline 23 (AN1) & 255461 & 4717875 & Middle Ilerdian & & & $095 / 45$ & 8 & $336 / 43$ & 6.4 & 75.1 & & & \\
\hline 23 (AN1) & 255461 & 4717875 & Middle Ilerdian & & & $095 / 45$ & 8 & $142 /-4$ & 12.5 & 20.6 & & & \\
\hline 24 (AN2) & 261380 & 4720904 & Lower Ilerdian & Añisclo anticline & $155 / 06$ & $006 / 79$ & 4 & $182 /-36$ & 10 & 26 & & & \\
\hline 25 (AN3) & 264261 & 4719592 & Lower Ilerdian & Añisclo anticline & $155 / 06$ & $144 / 05$ & 12 & $204 /-17$ & 7 & 37 & & & \\
\hline 26 (AN4) & 255359 & 4717714 & Middle Ilerdian & & & $040 / 05$ & 11 & $021 / 33$ & 6 & 60 & & & \\
\hline 27 (BL1) & 264043 & 4713214 & Upper Ilerdian & Añisclo anticline & $175 / 10$ & $068 / 33$ & 10 & $024 / 39$ & 3 & 276 & & & \\
\hline 28 (BL2) & 255208 & 4710255 & Upper Ilerdian & Boltaña anticline & $185 / 0$ & $274 / 83$ & 3 & $057 / 58$ & 24 & 27 & & & \\
\hline 29 (BL3) & 255847 & 4710475 & Upper Ilerdian & Boltaña anticline & $185 / 0$ & $092 / 17$ & 6 & $196 /-26$ & 6 & 132 & & & \\
\hline 30 (BL4) & 260898 & 4710445 & Middle Ilerdian & Añisclo anticline & $185 / 20$ & $200 / 20$ & 9 & $221 /-23$ & 8 & 48 & & & \\
\hline 31 (BL5) & 259503 & 4712061 & Middle Ilerdian & Añisclo anticline & $175 / 10$ & $081 / 90$ & 11 & $204 /-26$ & 5 & 85 & & & \\
\hline 32 (BL6) & 267643 & 4710863 & Upper Ilerdian & & & $146 / 04$ & 11 & $033 / 30$ & 2 & 582 & & & \\
\hline 33 (BL7) & 256609 & 4711485 & Upper Ilerdian & Boltaña anticline & $185 / 0$ & $110 / 26$ & 7 & $198 /-27$ & 10 & 42 & & & \\
\hline $\begin{array}{l}34 \\
(B L 10)\end{array}$ & 258686 & 4713538 & Upper Ilerdian & Añisclo anticline & $175 / 10$ & $090 / 10$ & 8 & $220 /-45$ & 16 & 14 & & & \\
\hline $\begin{array}{l}35 \\
\text { (BL11) }\end{array}$ & 259195 & 4712972 & Middle Ilerdian & Añisclo anticline & $175 / 10$ & $080 / 84$ & 11 & $201 /-16$ & 17 & 12 & & & \\
\hline $\begin{array}{l}36 \\
(B L 12)\end{array}$ & 268580 & 4710575 & Upper Ilerdian & & & $030 / 20$ & 11 & $027 / 36$ & 5 & 104 & & & \\
\hline
\end{tabular}

published paleomagnetic data (Table S1 in supporting information) display systematic variations around the Ainsa Oblique Zone (Figures 3 and 11). Practically all the samples record a clockwise vertical axis rotation. Barring remagnetized sites, mean values range from $\sim 80^{\circ} \mathrm{CW}$ rotation (sites 3 and 7, lower Lutetian materials near the Mediano anticline) to $\sim 20^{\circ} \mathrm{CW}$ (primary component of site 23, middle Ilerdian (early Ypresian) materials cropping out at the northern edge of the Añisclo anticline) (Table 1). Plotted on a map, these values reveal a clear pattern in the magnitude of vertical axis rotation through space and time (Figure 11).

[58] Sites eastward of the studied area, in the central parts of the Montsec and Bóixols thrust sheets, do not record any significant rotation, consistently with paleomagnetic data located further east [Dinarès-Turell, 1992; Beamud et al.,
2003] (Figure 11). An axial surface of rotation can be defined east of the study area (Figure 11), delineating the boundary between the nonrotated areas of the south central Pyrenees and the areas of the Montsec and Gavarnie thrust sheets that have experienced $\mathrm{CW}$ vertical axis rotation. This axial surface coincides with the eastern edge of the circular bend connecting the $\mathrm{N}-\mathrm{S}$ trending structures of the Ainsa Oblique Zone and the western edge of the Montsec thrust sheet with the E-W to WNW-ESE structural trend further east (Figure 11). The intersection between this eastern axial surface and the thrust front of Serres Marginals-Sierras Exteriores is characterized by a thrust reentrant (Figure 11).

[59] From the eastern axial surface, the amount of clockwise rotation increases westward toward the central part of the studied area, where structures predominantly trend $\mathrm{N}-\mathrm{S}$, both in the hanging wall of the Peña Montañesa- 
Table 1. Geographic, Stratigraphic, Structural, and Paleomagnetic Information of the Studied Sites ${ }^{\text {a }}$

\begin{tabular}{|c|c|c|c|c|c|c|c|c|c|}
\hline \multicolumn{6}{|c|}{ Magnetic Components } & \multirow{2}{*}{\multicolumn{3}{|c|}{$\begin{array}{c}\text { Magnetic Stability } \\
\text { and Age } \\
\text { (7) }\end{array}$}} & \multirow{3}{*}{$\begin{array}{c}\beta \text { Net rotation } \\
\text { Reference direction } \\
\mathbf{0 0 4 / 5 3} \\
{[\text { Taberner } \text { et al., 1999] }}\end{array}$} \\
\hline \multicolumn{6}{|c|}{$\begin{array}{l}\text { Bed. Corr. } \\
\text { (6) }\end{array}$} & & & & \\
\hline $\mathrm{D}(\mathrm{abc})$ & corr3 & D\&I (abc) & $\alpha 95$ & $\mathrm{~K}$ & Dec_err & Fold Test & $\%$ unfold & Stability & \\
\hline & cyl & $237.9 /-43.7$ & 5 & 109 & 6.92 & & & & $54+/-10.3$ \\
\hline 199 & con & $193.4 /-23$ & 6 & 115 & 6.52 & & & & $9+/-10$ \\
\hline \multirow[t]{2}{*}{86.7} & con & $83.6 / 58.8$ & 8 & 24 & 15.44 & $\mathrm{~S}$ & 85.82 & pre & $79+/-17.2$ \\
\hline & cyl & $34.6 / 40$ & 8 & 60 & 10.44 & $\mathrm{~S}$ & 85.82 & pre & $31+/-12.9$ \\
\hline \multirow[t]{4}{*}{53.2} & con & $59.4 / 46.5$ & 6 & 98 & 8.72 & $\mathrm{~S}$ & 85.82 & pre & $55+/-11.6$ \\
\hline & cyl & $26.9 / 46.2$ & 8 & 52 & 11.56 & & & & $23+/-13.9$ \\
\hline & cyl & $82.2 / 60$ & 6 & 56 & 12.00 & $\mathrm{~S}$ & 85.82 & pre & $78+/-14.2$ \\
\hline & cyl & $60.9 / 49.4$ & 11 & 29 & 16.90 & $\mathrm{~S}$ & 85.82 & pre & $57+/-18.5$ \\
\hline 18.9 & con & $23.4 / 38$ & 15 & 20 & 19.04 & $\mathrm{~S}$ & 85.82 & pre & $19+/-20.5$ \\
\hline 34.1 & con & $40 / 54.2$ & 12 & 28 & 20.51 & $\mathrm{~S}$ & 85.82 & pre & $36+/-21.9$ \\
\hline 218.5 & con & $219.8 /-41.8$ & 13 & 24 & 17.44 & & & & $36+/-19$ \\
\hline \multirow[t]{3}{*}{238.1} & con & $239.9 /-55$ & 12 & 35 & 20.92 & & & & $56+/-22.3$ \\
\hline & cyl & $217.2 /-36.4$ & 13 & 52 & 16.15 & & & & $33+/-17.9$ \\
\hline & cyl & $223.2 /-55$ & 18 & 19 & 31.38 & & & & $39+/-32.3$ \\
\hline \multirow{23}{*}{43.1} & con & $51.9 / 54.8$ & 9 & 27 & 15.61 & $\mathrm{O}$ & 97.26 & pre & $48+/-17.4$ \\
\hline & cyl & 209/-44 & 7.3 & 57.8 & 10.15 & $\mathrm{~S}$ & 120.54 & pre & $25+/-12.4$ \\
\hline & cyl & $250 /-40$ & 17.6 & 15.4 & 22.98 & $\mathrm{~S}$ & 120.54 & pre & $66+/-24.7$ \\
\hline & cyl & $235 /-35$ & 22.2 & 7.2 & 27.10 & $\mathrm{~S}$ & 120.54 & pre & $51+/-27.9$ \\
\hline & cyl & $241 /-46$ & 12.5 & 29.8 & 17.99 & $\mathrm{~S}$ & 120.54 & pre & $57+/-20.2$ \\
\hline & cyl & $236 /-60$ & 9.5 & 41.6 & 19.00 & $\mathrm{~S}$ & 120.54 & pre & $52+/-21.4$ \\
\hline & cyl & $075 / 48$ & 23 & 9.4 & 34.37 & $\mathrm{~S}$ & 120.54 & pre & $71+/-35.2$ \\
\hline & cyl & $074 / 52$ & 10 & 27.3 & 16.24 & $\mathrm{~S}$ & 120.54 & pre & $70+/-17.9$ \\
\hline & $\mathrm{bc}$ & $24 / 45$ & 6 & 76 & 8.49 & & & & $20+/-11.4$ \\
\hline & $\mathrm{bc}$ & $155 /-31$ & 12 & 24 & 14.00 & & & post & $?$ \\
\hline & $\mathrm{bc}$ & $181 /-29$ & 10 & 26 & 11.43 & & & & $-3+/-13.7$ \\
\hline & $\mathrm{bc}$ & $205 /-16$ & 7 & 37 & 7.28 & & & & $21+/-10.5$ \\
\hline & $\mathrm{bc}$ & $021 / 28$ & 6 & 60 & 6.80 & & & & $17+/-10.2$ \\
\hline & $\mathrm{bc}$ & $034 / 12$ & 3 & 219 & 3.07 & & & post? & $30+/-8.2$ \\
\hline & $\mathrm{bc}$ & $073 / 19$ & 24 & 27 & 25.38 & & & & $69+/-26.5$ \\
\hline & $\mathrm{bc}$ & $203 /-20$ & 6 & 131 & 6.39 & & & & $19+/-9.9$ \\
\hline & $\mathrm{bc}$ & $225 /-40$ & 8 & 45 & 10.44 & $\mathrm{~S}$ & 5.61 & post? & $41+/-12.9$ \\
\hline & $\mathrm{bc}$ & $139 /-30$ & 5 & 73 & 5.77 & S & 5.61 & post & $\begin{array}{c}20+/-9.6 \\
\text { (minimum) }\end{array}$ \\
\hline & $\mathrm{bc}$ & $036 / 33$ & 2 & 504 & 2.38 & $\mathrm{~S}$ & & post? & $32+/-8$ \\
\hline & $\mathrm{bc}$ & $211 /-25$ & 10 & 42 & 11.03 & & & & $27+/-13.4$ \\
\hline & $\mathrm{bc}$ & $227 /-38$ & 20 & 15 & 25.38 & $\mathrm{~S}$ & 5.61 & post? & $43+/-26.5$ \\
\hline & $\mathrm{bc}$ & $146 /-26$ & 9 & 33 & 10.01 & S & 5.61 & post & $\begin{array}{c}18 \text { (minimum) }_{t /-12.6} \\
\text { minum }\end{array}$ \\
\hline & $\mathrm{bc}$ & $029 / 16$ & 5 & 100 & 5.20 & & & post? & $25+/-9.2$ \\
\hline
\end{tabular}

Montsec thrust sheet and in the Ainsa Basin. In this area, data presented in this study (Figure 3) and previous work (Figure 2) reveal rotations between $\sim 25^{\circ}$ and $80^{\circ} \mathrm{CW}$ (Figure 11). West of the Ainsa Oblique Zone, where structures trend WNW-ESE, clockwise vertical axis rotations decrease to an average value of $10^{\circ}$ to slightly higher values (Figure 11). According to Dinarès-Turell [1992], Bentham [1992], and Pueyo [2000], a regional background rotational base value of $15^{\circ}-20^{\circ}$ can be assumed for the GavarnieSierras Exteriores thrust sheet, recorded in the youngest sediments sampled, in the Escanilla and Campodarbe Fms. [Pueyo, 2000; Bentham, 1992; Mochales et al., 2012b]. Therefore, in the $\mathrm{N}-\mathrm{S}$ trending structures of the Ainsa Oblique Zone, the differential vertical axis rotation values recorded by the Eocene sediments with respect to the Gavarnie-Sierras Exteriores regional value are in the order of $10^{\circ}-70^{\circ}$ (Figure 11).

[60] Vertical axis rotations have been recorded all along the Sierras Exteriores structures [Oliva-Urcia et al., 2012a;
Ramón et al., 2012; Pueyo-Anchuela et al., 2012]. Further west, in the western Pyrenees, no significant vertical axis rotations have been recorded by paleomagnetic data [Larrasoaña et al., 2003], defining a western limit for vertical axis rotation.

[61] CW vertical axis rotation can be further constrained to the hanging wall of the Gavarnie thrust and the older thrust sheets transported piggyback in its hanging wall. Paleomagnetic data recorded in the north of the study area as well as westward, along the northern Mesozoic and Paleogene rocks of the Gavarnie thrust sheet (Sierras Interiores) [Oliva-Urcia and Pueyo, 2007b; Oliva-Urcia et al., 2012b], indicate that the Triassic red beds in the footwall of the Gavarnie thrust sheet, north of the Cotiella thrust sheet, have not experienced any significant vertical axis rotation (Figure 2) [Oliva-Urcia et al., 2012b]. This is further confirmed by the absence of any major structural bend or curvature in the lower, younger basement-involved thrust sheets below the Gavarnie thrust north of the Ainsa Oblique Zone (Figure 2). 


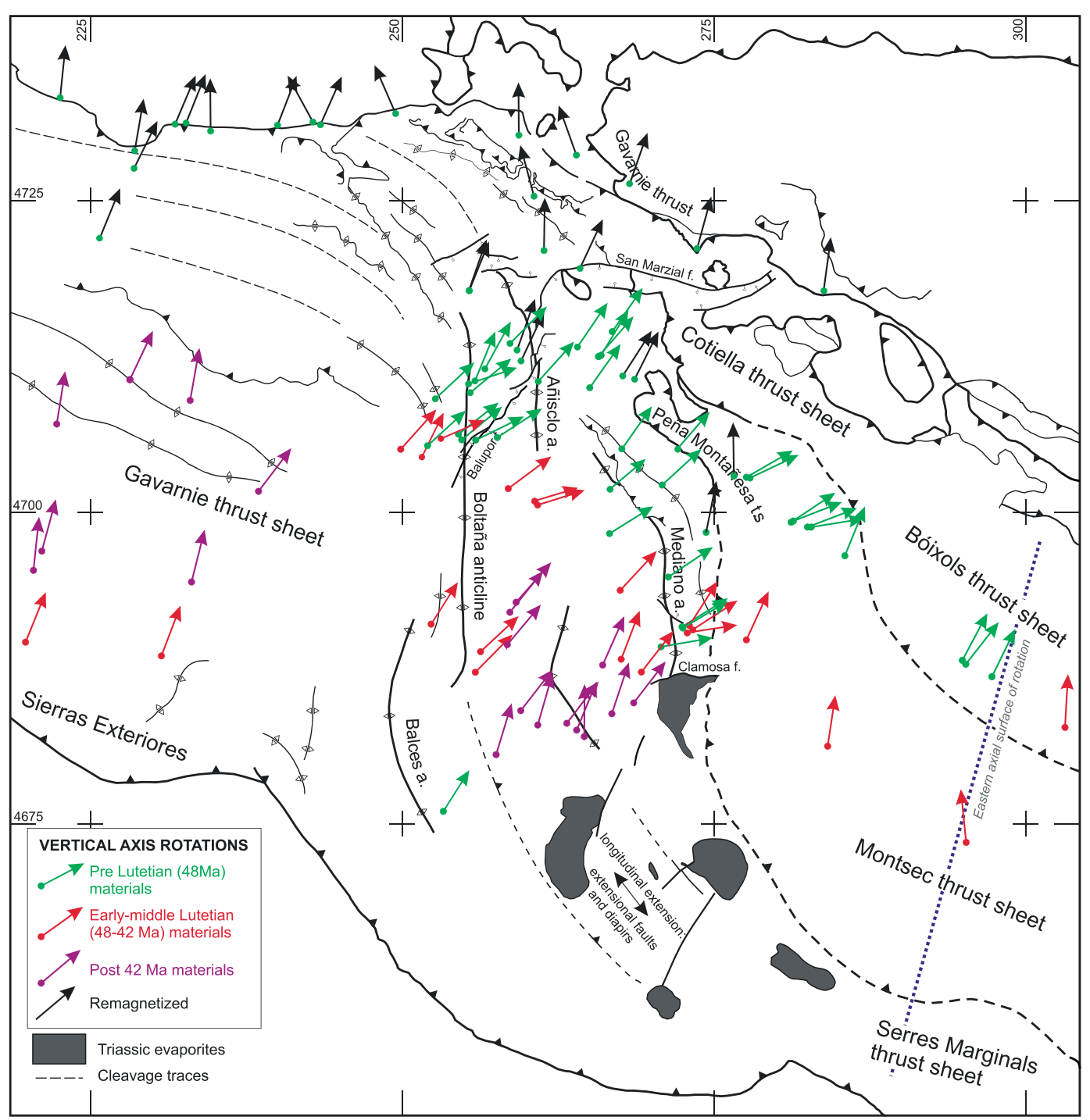

Figure 11. Simplified map and sketch of the vertical axis rotations within the study area. Vertical axis rotations are grouped in three categories according to the age of the sampled sediments. Remagnetized sites are distinguished as black arrows. f, fault; a, anticline; t.s., thrust sheet.

[62] The amount of $\mathrm{CW}$ vertical axis rotation depends also on the age of the sampled sediments. The highest values of rotation have been recorded by the Lower Eocene sediments, and these values generally decrease with age (Figure 11). Mediano anticline is the area where the relationship between age and amount of rotation can be established best (Figures 6 and 12a). If data from the present study are combined with data by Dinarès-Turell [1992] and Bentham [1992], data cover sediments from Ilerdian to upper Lutetian age over a relatively small area within which there are no major faults, making it reasonable to assume that there are no local factors interfering with regional rotation. It can be observed that rotations between $58^{\circ}$ and $80^{\circ}$ are recorded in sediments of Ilerdian and Cuisian age and in one sample of lower Lutetian age (site 3). The magnitude of rotation then decreases progressively through Lutetian times to reach minimum values of rotation during the upper Lutetian to Bartonian $\left(15^{\circ}\right.$ to $\left.35^{\circ}\right)$ (Figures 3, 6, 11, and 12a).

[63] This pattern of decreasing rotation with age is also observed across the Boltaña anticline along the Ara River.
Sites in the prefolding sequence of Cuisian age (sites 18, 19, and D21 and Figures 7 and 12b) and lower Lutetian age (sites 17, 20, 21, and 22 and Figures 3, 7, and 12b) present CW rotations ranging from $50^{\circ}$ to $70^{\circ}$, whereas younger upper Lutetian sediments located above the unconformity at the bottom of the synfolding package present less rotation, although still significant (site 16 and sites from Pueyo [2000]) (Figures 7 and 12b). Considering the sites of our study and the sites recently published by Mochales et al. [2012b], an average $\mathrm{CW}$ vertical axis rotation of $\sim 55^{\circ}$ can be estimated for the prefolding sediments in this transect of the Boltaña anticline (Figure 12b). Unpublished data by Mochales [2011] in the middle Lutetian-Bartonian growth sediments on the western limb of the Boltaña anticline, in the area of the map in Figure 7, confirm the decrease of the rotation with age in the synfolding sediments and therefore the synchronicity between folding and vertical axis rotation. If we plot together our data with the data set from Mochales et al. [2012b], including data for the southern edge of the Boltaña anticline, a linear fit with an almost constant $\mathrm{CW}$ vertical axis rotation of about $50^{\circ}$ is 

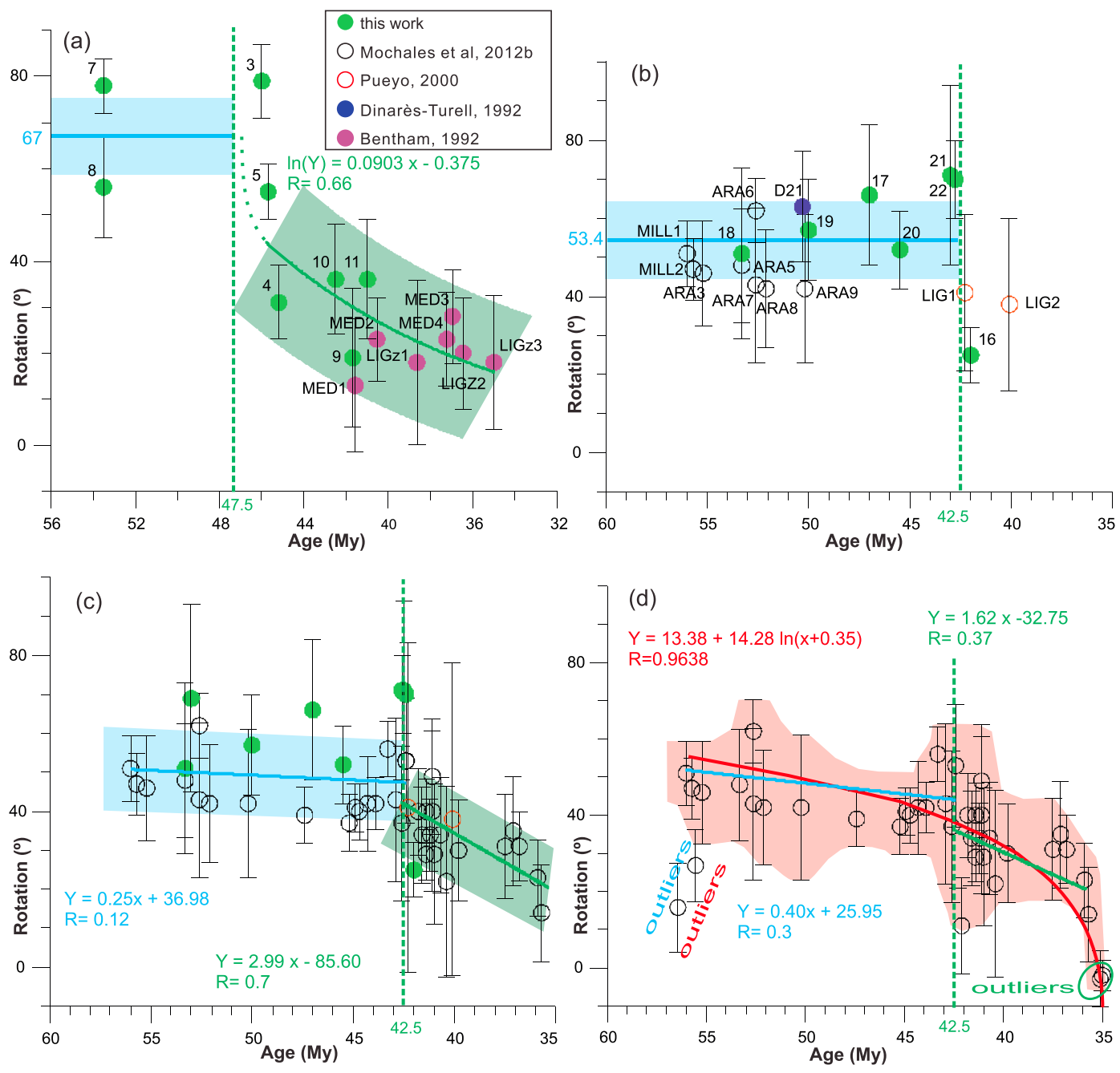

Figure 12. Rotation versus time plots for the Mediano (a) and the Boltaña anticlines (b to d). (a) Data for the Mediano anticline from this study and from Bentham [1992] as cited in Mochales et al. [2012b]. Blue line within the amount of rotation represents the mean rotational angle for the data before the growth of the structure at $47.5 \mathrm{Ma}$. After 47.5 Ma, the data follow a decreasing exponential function. (b) Data from this and previous studies along the Ara River transect (sites located in Figure 7). Blue line within the amount of rotation represents the mean rotational angle for the data before the growth of the structure at 42.5 Ma, the light blue band represents a $+/-10^{\circ}$ envelope. (c) Data from this work and from previous studies fit by linear regressions before and after $42.5 \mathrm{Ma}$. Sites marked as outliers in Figure $12 \mathrm{~d}$ have been removed in this plot, as well as site CAS5 from Mochales et al. [2012b]. (d) Data from Mochales et al. [2012b] with logarithmic and linear regression adjustments. Red line represents the logarithmic adjustment published in Mochales et al. [2012b]. Blue line represents a new linear regression for data before the growth of the anticline at $42.5 \mathrm{Ma}$. Green line represents the linear regression for data within the growth strata. Sites marked as outliers in the figure have not been included to calculate the regression lines.

obtained for the older sediments cropping out in the core of the Boltaña anticline (Ypresian-lower Lutetian) (Figure 12c). Most significantly, a change in the rotational pattern is observed at about $42.5 \mathrm{Ma}$ : the age of the oldest sediments above the unconformity on the western limb of the Boltaña anticline and therefore the interpreted onset of fold growth. Younger sediments show a decrease in the amount of vertical axis rotation with time from middle Lutetian to Priabonian times (Figures 12c and 12d).

[64] Apart from the regional E-W gradient of the vertical axis rotation across the $\mathrm{N}-\mathrm{S}$ trending structures of the Ainsa Oblique Zone and differences with the age of the sampled sediments, a north-south gradient is observed in map view along the N-S trending folds. This gradient stands out very clearly along the Boltaña and Añisclo anticlines (Figures 3 and 11). Highest rotation values are located in the central part of the Boltaña anticline and in the southern termination of the Añisclo anticline (Figure 11). These values decrease progressively northward, regardless of the continuation of the folds northward with a near-constant N-S trend. Such a decrease of the rotation angle is the result of the superposition of two effects. The most evident one is the remagnetization of internally deformed areas near the northern terminations of the Añisclo and Boltaña anticlines, north of the 
REGIONAL

1)
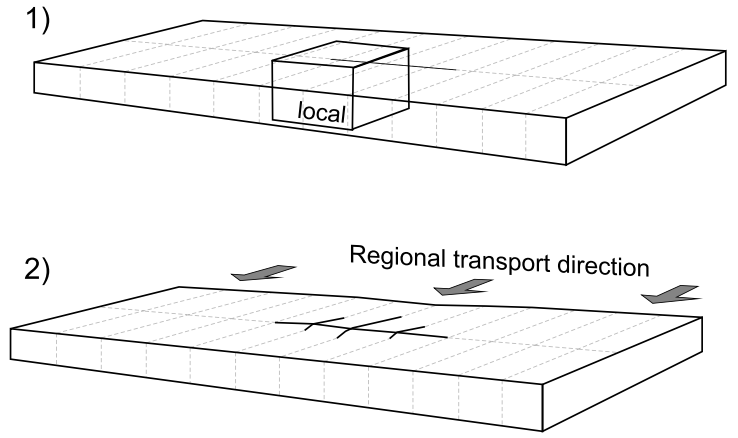

3)

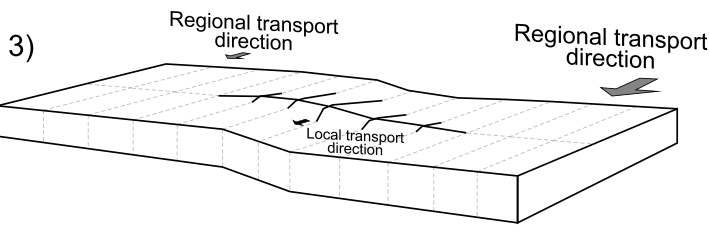

4)
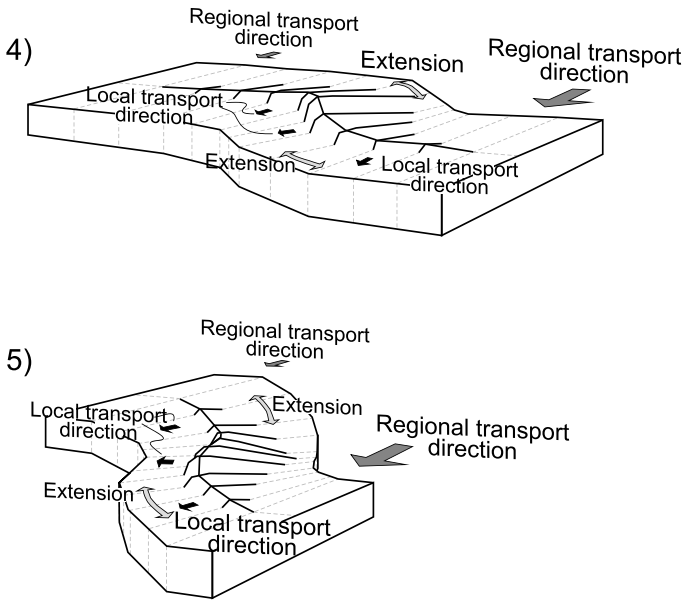

LOCAL
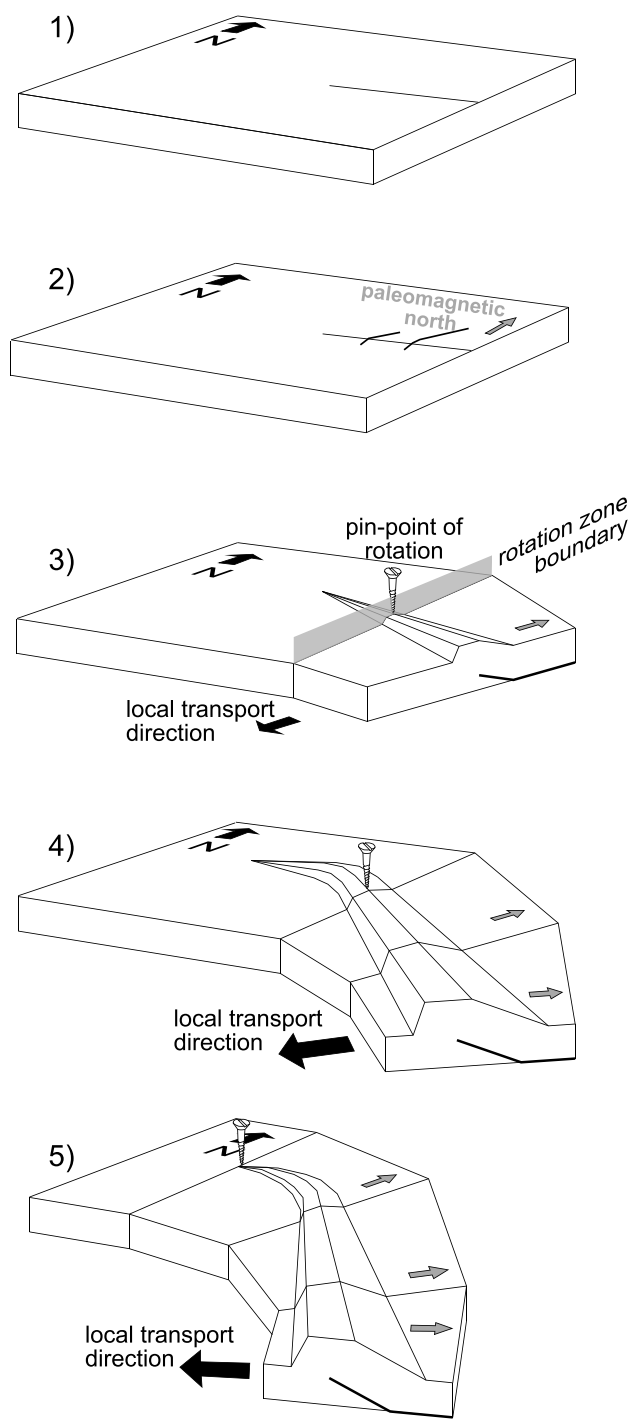

Figure 13. Schematic diagram showing the different stages of the evolution of the main fault-related folds of the Ainsa Oblique Zone and their longitudinal propagation during the $\mathrm{CW}$ vertical axis rotation. The box in stage 1 of the regional evolution marks the area enlarged and shown in the local evolution section (growth of the Boltaña anticline). Note the differences on the amount of vertical axis rotation along strike in the fold termination despite the constant strike of the fold. Regional and local transport directions are distinguished. Grey arrows on local evolution section represent paleomagnetic directions.

cleavage front [Oliva-Urcia and Pueyo, 2007b; OlivaUrcia et al., 2008]. However, a true gradient in the amount of vertical axis rotation along strike is also observed when taking account the primary component of sites 23 and 26. This rotational gradient can be explained by the lateral propagation of folds during synrotational folding and a related migration of the pinpoint of vertical axis rotation during fold growth and rotation (Figure 13).

[65] The La Fueba fold and thrust structures and the Peña Montañesa thrust sheet show a significant $\mathrm{CW}$ vertical axis rotation with values higher than $35^{\circ}$ and up to $80^{\circ}$, with the exception of site 2 , which has been probably remagnetized as discussed before or reveals the effect of local deformation (Figure 11). In the area where thrusts and folds of the La Fueba system trend NW-SE, the declination is roughly perpendicular to the thrust trend and parallel to the main and earlier striations along the shear planes (Figures 3, 8, and 11). Further south where thrusts bend to a more N-S trend, the amount of vertical axis rotation also increases (site 1). Conversely, further north, in the Cinca valley where the structural trend is also $\mathrm{N}-\mathrm{S}$, as indicated by the orientation of cleavage, the amount of vertical axis rotation decreases to values of $30^{\circ}$ (sites 27, 32, and 36 from this study and D15, D16, D17, and D18 from Dinarès-Turell [1992]). This reveals a rotation gradient in a $\mathrm{N}-\mathrm{S}$ direction that is similar to what is observed further west in the Añisclo and Boltaña anticlines related to the northward migration of the rotational pinpoint (Figure 13).

\subsection{Paleomagnetic Directions Versus Structural Trend}

[66] A strike test has been performed in order to evaluate changes in the paleomagnetic data with respect to the 


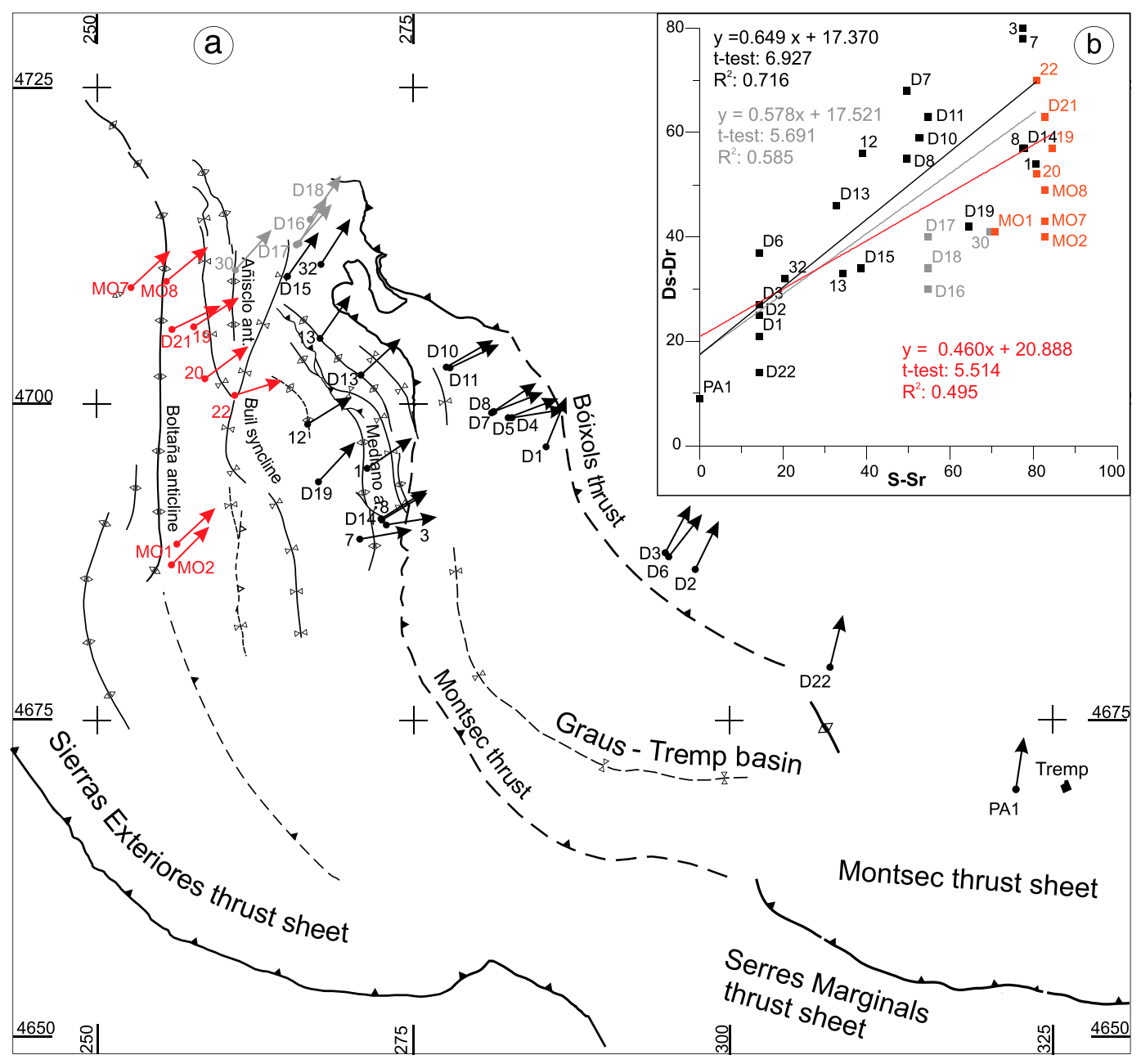

Figure 14. (a) Simplified structural map with location of the paleomagnetic sites used for the strike test of the study area. PA1 from Pascual et al. [1992]. Only sites from pretectonic units with $\alpha_{95}$ less than $15^{\circ}$ have been considered (see supporting information Table S2 for details). Red dots represent sites from the Boltaña anticline, and the grey ones represent sites suspicious of being remagnetized. (b) Strike test for the Ainsa Oblique Zone. Regression lines and $t$ test parameters for the significance of the slope of the obtained regression are indicated. Black line represents the regression taking into account only the sites represented in black (without the Boltaña sites and the ones suspicious of being remagnetized). Grey line represents the regression taking into account black and grey sites (without the Boltaña sites). Finally, all the sites (black, grey, and red) have been considered to obtain the red regression line.

structural trend (Figure 14 and Table S2 in supporting information) [Schwartz and Van der Voo, 1983; Eldredge et al., 1985; Lowrie and Hirt, 1986; Yonkee and Weil, 2010b]. Application of this test is not straightforward in the study area, regardless the significant amount of available paleomagnetic data and the pronounced change of strike of the Ainsa Oblique Zone structures with respect the regional Pyrenean structural trend (Figure 11). Difficulty of the application of the strike test is due to the syntectonic nature of most of the sampled sediments, the remagnetization of the sites located in the most deformed northern areas, and the longitudinal growth of structures during the vertical axis rotation (Figure 13). Strike tests were designed to be applied in pretectonic rocks on long, linear, continuous mountain belts [Schwartz and Van der Voo, 1983; Lowrie and Hirt, 1986]. In the study area, evaluation of the tectonic curvature by the strike test requires a filtering of the sites. Accordingly, we have only used nonremagnetized sites in prefolding sediments located near the core of the structures. In addition, we have rejected the sites that yield paleomagnetic directions with high dispersion $\left(\alpha_{95}>15^{\circ}\right)$ or anomalous inclination (Table S2).

[67] The structural trend for each plotted site has been calculated from the analysis of bedding (about 5000 dip measurements in the study area) and fold trace data. For the sites located eastward of the study area, the structural trend has been estimated from structural map patterns of the main structures at kilometric-scale areas. In this way, we have reduced to a minimum the dispersion of individual strike values of bedding and averaged out local noise.

[68] The strike test on filtered data of the study area including areas further east (where structures show a regional Pyrenean WNW-ESE trend) yielded a slope of the regression line of 0.46 and a $t$ test for the significance of the slope of 5.514 (red line in Figure 14). This value is higher than the $t$ 
for the null hypothesis at $95 \%$ of probability (2.045), and therefore, the obtained slope is significant. If sites from the Boltaña anticline are removed from the analysis because of its younger age (grey line in Figure 14), the slope of the strike test for the sites along the older and inner structures of the Gavarnie thrust sheet increases to 0.58 with a $t$ test value of 5.69. In this case, the slope of the regression line is also significant as the $t$ for the null hypothesis at $95 \%$ probability is smaller (2.080) than the obtained $t$ test value. Finally, if sites suspicious of remagnetization in these inner structures are also removed in the strike test (black line in Figure 14), both the slope and the $t$ test values increase to 0.649 and 6.927 , respectively. This regression is also significant as $t$ is bigger than the $t$ for the null hypothesis at $95 \%$ probability $(2.093)$.

[69] All these values indicate that the studied thrust salient is a progressive arc with about $50 \%$ secondary curvature related to vertical axis rotation. For the older structures of the Gavarnie thrust sheet, secondary curvature would represent up to $65 \%$.

\section{Discussion: Structural Evolution and Kinematics}

[70] From all the above described structural features and the paleomagnetic data, it follows that there is an obvious relationship between the $\mathrm{N}-\mathrm{S}$ trend of structures in the Ainsa Basin and the $\mathrm{CW}$ vertical axis rotations recorded by the measured paleomagnetic directions. The $\mathrm{N}-\mathrm{S}$ trend is a consequence of $\mathrm{CW}$ rotation of the entire Ainsa Oblique Zone, synchronous to the growth of the folds, indicating that the curvature is progressive in origin. However, determining the precise kinematics and origins of this vertical axis rotation is not possible without integrating paleomagnetic data with structural, sedimentological, and orogen-scale constraints.

[71] The importance of integrating other types of data when interpreting paleomagnetic data in this area stems from the fact that the magnitude of the vertical axis rotation is not constant over the Ainsa Oblique Zone regardless the constant strike of the structures (as indicated by the significant dispersion of data in the strike test plot, Figure 14). The vertical axis rotation depends on many factors such as the position of sites relative to structures, the age of the sampled sediments, superposition of secondary magnetization during deformation, and local deformation by minor structures, among others. In addition to these different factors, paleomagnetic data may show significant error bars. As a consequence, when interpreting the paleomagnetic data of the area, significant different interpretations may arise with the same data set if the combination of the aforementioned factors is not borne in mind. Most importantly, the integration of the stratigraphic and structural data with the paleomagnetic data in this study has reduced uncertainties of the interpretation of the paleomagnetic data and constrained the proposed structural evolution for the Ainsa Oblique Zone. Analysis of paleomagnetic data and statistical tests or regressions to fit the distribution of data should be conditioned by geological constraints, as previously discussed for the strike test. Otherwise, the conclusions obtained may contradict geological field observations or regional scale constraints, and consequently, have no validity.

\subsection{Age and Magnitude of the Vertical Axis Rotation}

[72] Two distinct CW vertical axis rotation events can be defined in the study area: the first one during early Lutetian to Priabonian times, and the second one of Priabonian to Oligocene age.

[73] The older vertical axis rotation event (early Lutetian to Priabonian) is restricted to the Gavarnie thrust sheet and older thrust sheets in its hanging wall that were passively rotated (e.g., Montsec, Bóixols). Vertical axis rotation occurred during the emplacement of the Gavarnie-Sierras Exteriores thrust sheet (Middle to Late Eocene) and the development of the folds and thrusts of the Ainsa Oblique Zone. This synchronicity is documented by the rotation of the Mediano and Boltaña anticlines during growth. Both anticlines record significant $\mathrm{CW}$ vertical axis rotation in their pregrowth strata $\left(50^{\circ}-70^{\circ}\right)$ and progressively less rotation in their syngrowth strata. In the case of the Mediano anticline, whose growth starts during the early Lutetian [Poblet et al., 1998; Fernández et al., 2012], the decrease in the amount of rotation can be observed from 47.5 Ma (the age of the unconformity marking initial fold growth) [Poblet et al. 1998] onward (Figure 12a). Synfolding rotation of the Mediano anticline continued at a decreasing rate at least into the Priabonian (Figure 12a). A similar relationship between folding and vertical axis rotation is observed for the Boltaña anticline. Growth of this anticline starts at approximately $42.5 \mathrm{Ma}$ (as discussed above). This age threshold corresponds to a change in the magnitude of $\mathrm{CW}$ vertical axis rotation when analyzing data along a single transect across the Boltaña anticline (to reduce the potential impact of lateral gradients in vertical axis rotation, Figure 12b). This age coincides with the inflection point in the magnitudes of vertical axis rotation documented by Mochales et al. [2012b] at $\sim 42 \mathrm{Ma}$. Vertical axis rotation during the growth of the Boltaña anticline is interpreted to have been relatively constant in rate, although it might have decreased with time as in the case of the Mediano anticline (Figures 12b and 12c).

[74] This interpretation counters that by Mochales et al. [2012b], who propose the existence of a prefolding CW rotation of $15^{\circ}$ and an acceleration of vertical axis rotation after $42 \mathrm{Ma}$ (Figure 12d), based on the analysis of averaged data from different locations along the trend of the Boltaña anticline. However, given the significant lateral variations in vertical axis rotation recorded in the study area, a more conservative approach to analysis is required. As way of illustration, if data from the Boltaña anticline presented in this paper are added to the data by Mochales et al. [2012b], the prefolding rotation is no longer evident due to the greater scatter of data (which is due to the variations in vertical axis rotation of the anticline along strike and evidenced by a lack of correlation between age and rotation magnitude) (Figure 12c). Furthermore, the acceleration in the rate of vertical axis rotation documented by these authors is strongly conditioned by two facts. Firstly, their analysis is based on treating data from long before the onset of fold growth (more than $13 \mathrm{Ma}$ prior to onset of fold growth) and data synchronous with fold growth together, without allowing for the possibility of a change in the kinematics of vertical axis rotation prior to and synchronous with folding. Secondly, they incorporate in their analysis the two youngest samples, dated as $35 \mathrm{Ma}$, that yield a near zero vertical axis rotation (compare Figures 12c and 12d). However, sites sampled nearby by Bentham [1992] in sediments of the same age, although less robust than some of the data by Mochales et al. [2012b], yield CW vertical axis rotations of $\sim 20^{\circ}+/-10^{\circ}$ that 
are consistent with the existence of a second (PriabonianOligocene) regional $\mathrm{CW}$ vertical axis rotational event already solidly documented by multiple authors [Bentham, 1992; Pueyo, 2000; Oliva-Urcia and Pueyo, 2007b; Oliva-Urcia et al., 2012b] and discussed below.

[75] Synchronous with growth and rotation of the Sobrarbe folds, the previously developed La Fueba thrusts to the northeast were reactivated as oblique to dextral strike-slip faults as they were passively rotated as indicated by the spread in and superposition of fault kinematic indicators (Figure 8).

[76] During this first event of rotation, the process of vertical axis rotation continued to progress westward beyond the Boltaña anticline to the structures of the Sierras Exteriores [Millán et al., 2000]. Pueyo et al. [1997] suggested a diachronous end of the vertical axis rotation along the Sierras Exteriores from early Priabonian (Arguis area) to Late Oligocene at their western edge, overlapping temporally with the second rotation event and making them difficult to distinguish.

[77] At the last stages of this first rotational event (late Lutetian-Bartonian), a secondary magnetic component developed in the most deformed and internal areas affected by penetrative cleavage. The limited amount of rotation affecting this secondary component indicates it is mostly posterior to the main rotation event in the Gavarnie thrust sheet. OlivaUrcia and Pueyo [2007a, 2007b] suggested that the age of the remagnetized secondary component is younger than basement tilting in the hanging wall of the Gavarnie thrust but synchronous to cleavage development. In addition, these authors attributed the average $14^{\circ} \mathrm{CW}$ vertical axis rotation of this secondary component as well as the $8^{\circ} \mathrm{CW}$ rotation of the primary component in Upper Cretaceous sediments to a moderate rotation related to a gradient in shortening during the emplacement of the Guarga thrust sheet. The age of cleavage formation and remagnetization is consistent with the late stages of growth and $\mathrm{CW}$ vertical axis rotation of the Añisclo anticline, its related cleavage, and remagnetization of the forelimb where cleavage infilling occurred, as will be further discussed in the next subsection.

[78] The second and younger $\mathrm{CW}$ vertical axis rotation event, Priabonian-Oligocene in age, is responsible for the rotation of the remagnetized components. This event is related to the underthrusting of the Guarga basement unit below the northern parts of the Ainsa and Jaca Basins (Figures 1 and 15a) and the southward directed transportation of the previously deformed Mesozoic and Paleogene sediments of the Gavarnie-Sierras Exteriores thrust sheet [Martínez-Peña and Casas-Sainz, 2003; Fernández et al., 2012]. It affected a broader area than the previous one, including all the Sierras Exteriores (Figure 12). In this work, an average of $10^{\circ}$ has been attributed to this rotation event, taking into account not only paleomagnetic data of the internal areas [Oliva-Urcia and Pueyo, 2007b; OlivaUrcia et al., 2012b] but also the CW vertical axis rotation experienced by the younger sediments in the Sierras Exteriores and the sites located westward of the eastern axial surface of rotation (Figure 11).

[79] This second CW rotation event was enhanced by further southward displacement of the south Pyrenean thrust sheets in its central realm (Bóixols, Montsec, and Serres Marginals) on top of the Lower Priabonian-Oligocene (?) salts of the Ebro Basin. This is accompanied by a change in the structural configuration from a footwall flat along the Lower Priabonian evaporites under the Serres Marginals thrust sheet in the east [Teixell and Muñoz, 2000], to a footwall ramp cutting the equivalent age clastics under the Sierras Exteriores in the west [Millán et al., 2006; Pueyo et al., 2004]. The overall result is a change in the structural trend of the Sierras Exteriores and eastern Jaca Basin toward a more NW-SE trend (Figures 1 and 2).

[80] Rotation during this second event was synchronous with the $\mathrm{CCW}$ vertical axis rotation of about $20^{\circ}$ reported in the NE-SW trending oblique zone at the eastern edge of the central Pyrenees [Sussman et al., 2004].

[81] Once the space/time relationships between the oblique structures of the Gavarnie thrust sheet and the CW vertical axis rotations have been established, a cause-effect relationship can be assumed between them (as also indicated by the strike test of paleomagnetic data in the prefolding sediments, Figure 14). It can be interpreted that the onset of the vertical axis rotation was related to the onset of the contractional deformation in the Gavarnie thrust sheet. This onset was not synchronous and migrated from NE to SW. The oldest structures are the Mediano and Añisclo anticlines that started to develop at early Lutetian times (or even at late Cuisian times) as clearly revealed by the preserved growth sediments [Poblet et al., 1998; Fernández et al., 2012]. Onset of folding was coeval with the onset of vertical axis rotation as demonstrated by paleomagnetic data (Figures 6, 7, and 12). Deformation migrated to the SW to form the Boltaña anticline at middle Lutetian times, as did the onset of vertical axis rotation (Figures 7 and 12). An average total $\mathrm{CW}$ vertical axis rotation of $45^{\circ}$ to $55^{\circ}$ occurred during the development of the Boltaña and Mediano anticlines, once we subtract the younger Priabonian-Oligocene post folding rotation of at least $10^{\circ}$.

\subsection{Mesostructures Development and Remagnetization}

[82] Structures related to layer parallel shortening such as cleavage and fracture systems developed since the earlier stages of folding in the Ainsa Oblique Zone. These mesostructures, together with older structures in the $\mathrm{La}$ Fueba and Monte Perdido fold and thrust systems, experienced $\mathrm{CW}$ vertical axis rotation as they developed. They preserved the parallelism relative to fold axes because the local shortening direction remained perpendicular to the fold axes during $\mathrm{CW}$ vertical axis rotation due to divergent slip trajectories (that can be accounted for with a progressive curvature model).

[83] Regional pressure solution cleavage and fracture systems developed during the deformation of the Gavarnie thrust sheet and consequently during the $\mathrm{CW}$ vertical axis rotation that formed the Ainsa Oblique Zone. The development of the pervasive regional cleavage has been interpreted to occur in the Gavarnie thrust sheet at temperatures higher than $190^{\circ} \mathrm{C}$ and up to $240^{\circ} \mathrm{C}$, based on illite crystallinity data [Holl and Anastasio, 1995b] and oxygen isotope and fluid inclusion microthermometry analysis of veins related with the displacement of coeval thrusts [Lacroix et al., 2011]. Such temperature requires a significant burial of the youngest deformed lower Eocene turbidites, which can be estimated for a given geothermal gradient. Calculated paleogeothermal gradients in the area vary from $15^{\circ} \mathrm{C} / \mathrm{km}[$ Holl and 

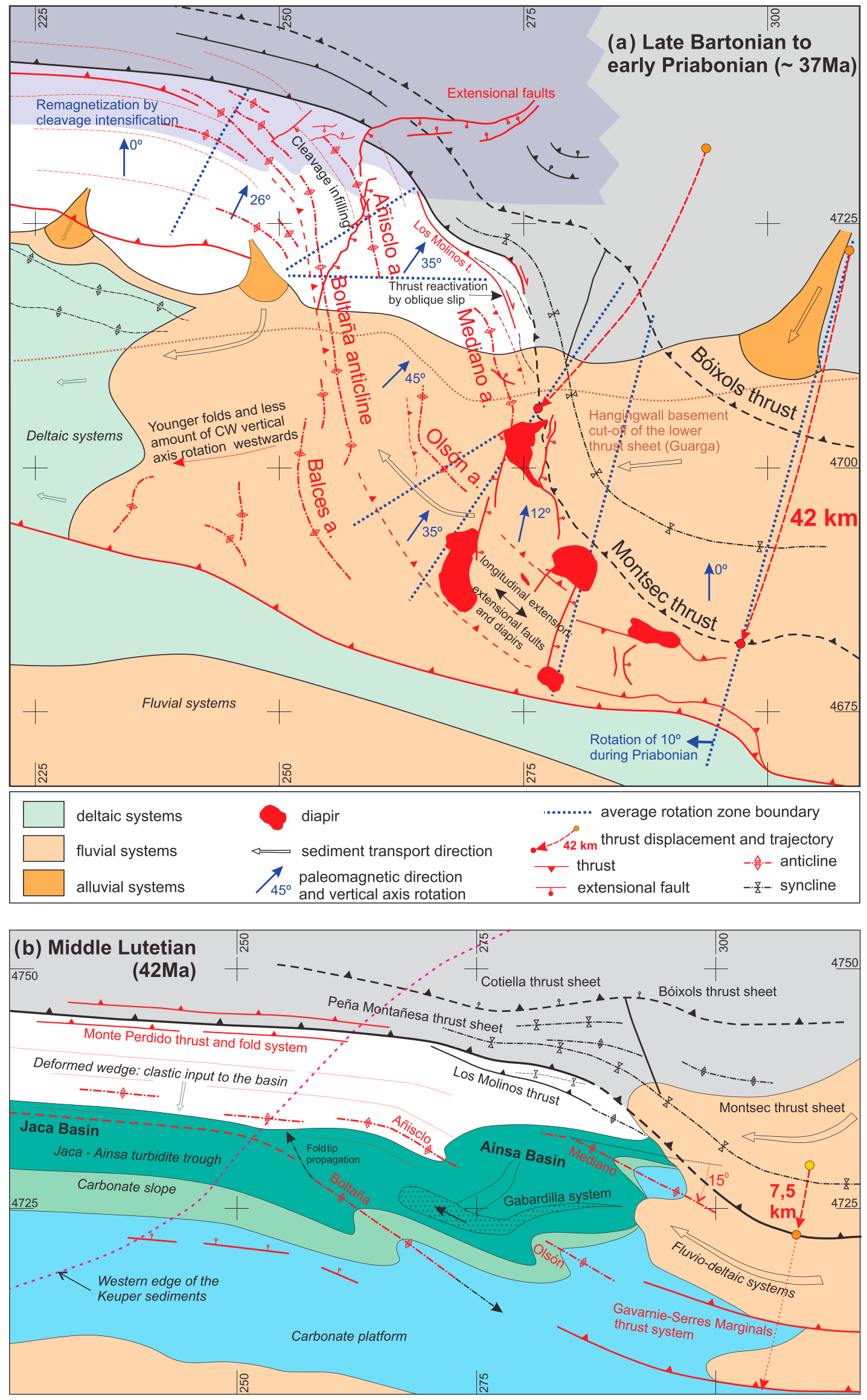

Figure 15 


\section{MUÑOZ ET AL.: PALEOMAGNETISM IN S PYRENEES}

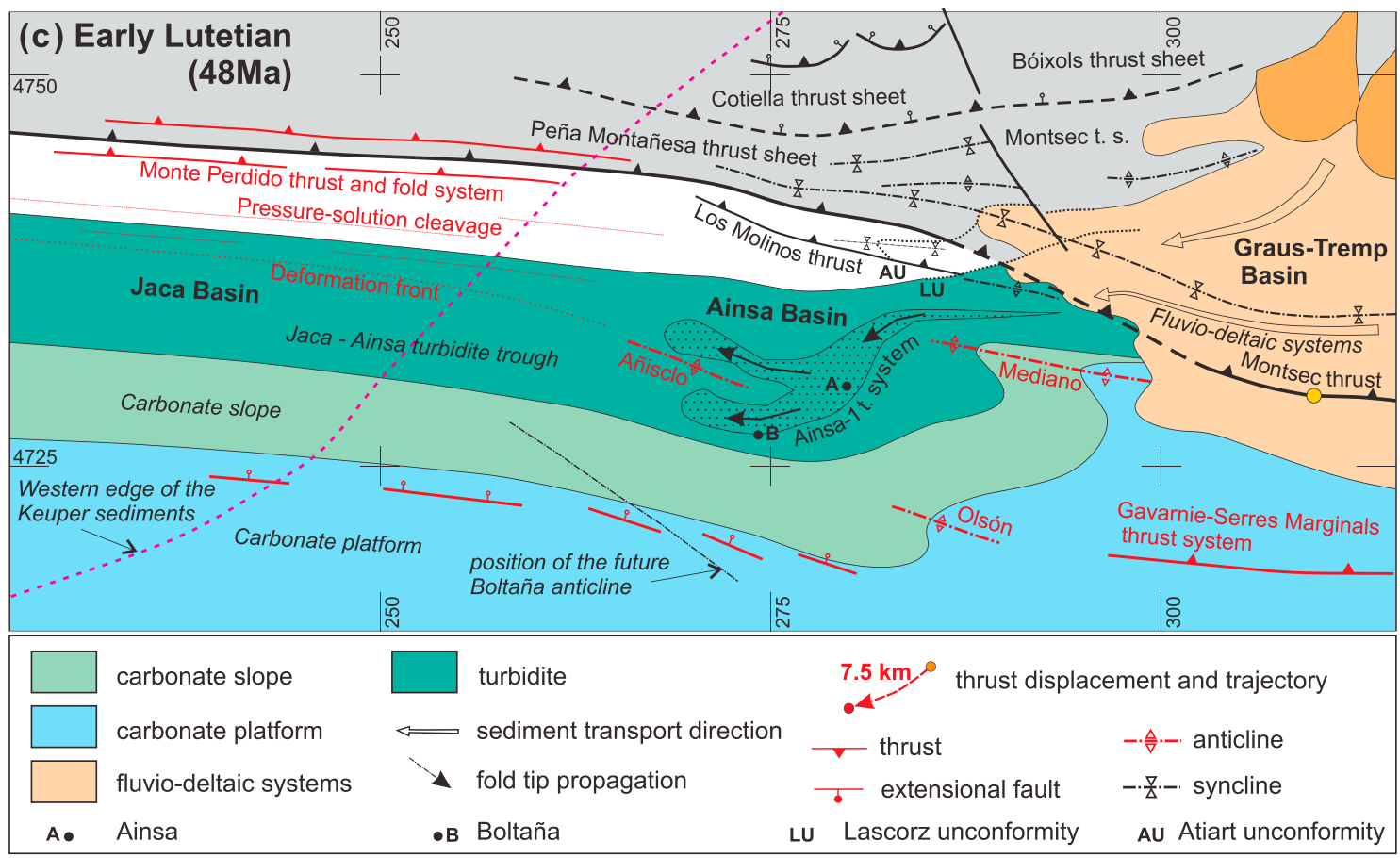

Figure 15. (continued)

Anastasio, $1995 \mathrm{~b}$ ] to $34^{\circ} \mathrm{C} / \mathrm{km}$ [Lacroix et al., 2011] giving a range of burial at the cleavage front between 12 and $6 \mathrm{~km}$, respectively. Such burial cannot be explained only by sediment burial of the synorogenic sediments. Burial resulted from thrust sheet stacking of the Monte Perdido thrust sheets and, mostly, the Cotiella-Peña Montañesa thrust sheets (with stratigraphy more than $5 \mathrm{~km}$ thick) above. Basement-involved lower and younger thrusts (Bielsa and Guarga thrusts among others, Late Eocene-Miocene in age) were responsible for the subsequent tilting and exhumation of the Cotiella, Peña Montañesa, and Gavarnie thrust sheets in the northern part of the studied area, and as a consequence, they decreased tectonic burial as they developed (Figure 2). The southern tip of such tilt by basement underthrusting corresponds with the cutoff line of the Paleozoic basement in the hanging wall of the Guarga thrust sheet, which runs parallel to and near the trace of the Guarga synclinorium (Figures 2 and 15a) [Fernández et al., 2012].

[84] Cleavage started to develop in the footwall of the Peña Montañesa and Cotiella thrust sheets at late Ypresian to early Lutetian times when the La Fueba and Monte Perdido fold system formed. Cleavage is pervasive in the Monte Perdido system as it developed under the Peña Montañesa thrust sheet (present outcrops are located northward of the Castillo Mayor klippe, under the now eroded western prolongation of the Peña Montañesa thrust, Figure 2). In the La Fueba system, cleavage is restricted to the areas near the axial surface of the fault-related folds at hectometric to regional scale. Cleavage continued its development during the middle Lutetian to Late Eocene times when the Gavarnie thrust was active and the Sobrarbe fold system developed in its hanging wall.

[85] According to Tavani et al. [2006], a regional and delocalized spaced pressure solution cleavage developed in the Upper Cretaceous-Lower Eocene sediments since the early stages of folding by layer parallel shortening and continued developing during a late localized deformation stage by selective infilling of solution cleavage in the forelimb and in the near foreland. Cleavage in the Añisclo anticline developed about $1-2 \mathrm{~km}$ below the synorogenic topographic surface as growth sequences of the turbidites of the Ainsa Basin are well preserved (Figure 4). The location and age of these sediments constrain not only the burial depth but also the timing of fold growth and cleavage development as previously described.

[86] A pervasive remagnetization characterized by a high intensity reverse magnetic component has been observed in the rocks deformed by regional cleavage [Oliva-Urcia and Pueyo, 2007b; Oliva-Urcia et al., 2008, 2009, 2012b] and in the samples collected in the northern areas, where pressure solution cleavage is well developed (generally over $20 \%$ of shortening). The presumed mechanism for explaining this remagnetization is the liberation and reorientation of the magnetic carrying minerals in the cleavage domains as solution progressed during cleavage intensification [Evans and Elmore, 2006; Oliva-Urcia et al., 2008;

Figure 15. Map reconstructions of the Ainsa Oblique Zone for the Middle to Late Eocene time span. (a) Late Bartonian to early Priabonian ( $37 \mathrm{Ma}$ ), (b) Middle Lutetian (42 Ma) and (c) Early Lutetian (48 Ma). Colors represent facies and sedimentary systems. Red lines represent the active structures in every stage. Same legend for Figures $15 \mathrm{~b}$ and $15 \mathrm{c}$. 
Elmore et al., 2012]. According to Oliva-Urcia et al. [2008], remagnetization is post folding and post tilting of the basement in the Gavarnie thrust sheet, as suggested by the fold tests and the amount of vertical axis rotations observed with respect to other nonremagnetized sites. Nevertheless, folding and basement tilting in the hanging wall of the Gavarnie thrust sheet can be perfectly synchronous. Cleavage developed from the earliest stages of folding, and remagnetization must have been synchronous to the development of axial plane cleavage, if we accept the proposed mechanism. Consequently, remagnetization probably occurred at the last stages of folding, once a threshold in the amount of strain was achieved to permit the reorientation of minerals in the cleavage domains. Our data support this idea as the sites sampled in the forelimb of the northern part of the Añisclo anticline are remagnetized but they show a moderate $\mathrm{CW}$ vertical axis rotation $\left(21^{\circ}-25^{\circ}\right)$. These moderate angles of rotation would record the last stages of rotation of the Añisclo anticline after cleavage developed significantly in the forelimb. Remagnetization might also be a somewhat diachronous event; if it was synchronous with cleavage intensification at the last stages of folding and $\mathrm{CW}$ rotation in the Ainsa Oblique Zone, it would have occurred as deformation progressed west and south through time.

[87] During the middle Lutetian-early Bartonian time interval, which is the most probable age of cleavage intensification in the Gavarnie thrust sheet, reversal polarities are predominant. This could explain the observed reverse polarity in the remagnetized sampled sites. On the other hand, the moderate values of $\mathrm{CW}$ vertical axis rotation of the normal polarity sites 27,32 , and 36 and the high intensity of the NRM, together with their location in the highly cleavaged area trending $\mathrm{N}-\mathrm{S}$ east of the Añisclo anticline, suggest that they were affected by remagnetization at the last stages of $\mathrm{CW}$ vertical axis rotation. The normal polarity of the magnetization would fit with a remagnetization related with a cleavage that developed progressively during Middle and Late Eocene times in the Gavarnie thrust sheet and the $\mathrm{CW}$ vertical axis rotation at its eastern part. Further work should be conducted in the area to confirm these ideas. Finally, the moderate $\mathrm{CW}$ rotation of the remagnetized component in the Sierras Interiores during the second Late Eocene-Oligocene $\mathrm{CW}$ vertical axis rotation event would be also consistent with Middle to Late Eocene age for the remagnetization.

\subsection{Restoration and Structural Evolution}

[88] The structures of the Ainsa Oblique Zone have been restored in map view, taking into account paleomagnetic data as well as structural and sedimentological data (Figure 15). For simplification, the Ainsa Oblique Zone and surrounding areas have been split into regions with an average $\mathrm{CW}$ vertical axis rotation as recorded by prefolding strata.

[89] A first step of restoration consisted in the removal of the second and youngest (Priabonian-Oligocene) regional $\mathrm{CW}$ rotation of $10^{\circ}$ west of the defined eastern axial surface (Figure 15a). Although it may represent a minimum value, a slightly higher value of rotation would not change the paleogeographic reconstructions or the derived conclusions significantly. The displacement gradient along the south directed Pyrenean thrust required for this rotation is of $22 \mathrm{~km}$.
The axis of rotation related to this shortening gradient has been located in the western edge of the Sierras Exteriores as suggested by Pueyo et al. [2004] and Ramón et al. [2012]. It is located along strike of the frontal thrust $50 \mathrm{~km}$ west of the edge of the map in Figure 15a. Once the younger regional Priabonian-Oligocene vertical axis rotation has been restored, the resultant map shows a systematic variation of the mean magnetic declinations around the curved structural trends of the Ainsa Oblique Zone and western Montsec thrust sheet (Figure 15a). In the map of Figure 15a, only the amount of vertical axis rotation that occurred between middle Lutetian (43 Ma) and late Bartonian-early Priabonian (38-37 Ma) has been annotated. This represents the period of time during which all the structures of the Ainsa Oblique Zone were active. In the northern bend, $\mathrm{CW}$ vertical axis rotation increases as structures change their trend from E-W (090-100 azimuth) to $\mathrm{N}-\mathrm{S}$ (170 azimuth). In the central part of the Ainsa Oblique Zone, where structures trend $170^{\circ} \mathrm{N}$, rotation was maximum $\left(45^{\circ} \mathrm{CW}\right)$ during that period of time. $\mathrm{CW}$ vertical axis rotation then decreases again in the southern bend as structures change toward E-W trends. This rotational pattern, combined with the lack of significant rotation in adjacent areas, indicates that vertical axis rotations were associated with large-scale thrusting in the salient, as also expressed by the strike plot (Figure 14).

[90] A restored map at middle Lutetian times (42 Ma) illustrates the geometry and position of the main structures of the Gavarnie thrust sheet during the early stages of deformation (Figure 15b). Sobrarbe folds have been restored, taking into account the shortening calculated in the E-W cross sections (Figures 5 and 6) and the 3-D restoration based on the 3-D structural reconstruction made by Fernández et al. [2012]. Total displacement of the thrusts related with the Sobrarbe folds totals about $5 \mathrm{~km}$ [Fernández et al., 2012]. However, total shortening is greater as shortening taken up by folding needs to be added. In the southern section, across the Mediano anticline (Figure 6), a shortening of $7.5 \mathrm{~km}$ has been calculated. At middle Lutetian times, the onset of growth of the Boltaña anticline controlled the dispersal of the turbidite systems in the Ainsa Basin which were fed from fluvio-deltaic systems in the east. The Boltaña anticline grew as an oblique structure at the thrust front of the Gavarnie thrust sheet. The Boltaña anticline developed parallel to the Mediano anticline which had by then already experienced a CW vertical axis rotation of about $15^{\circ}$. Forward of the thrust front, the carbonate platform experienced extensional deformation by flexure of the foreland [Barnolas and Teixell, 1994; Tavani et al., 2012]. The tip of the Boltaña anticline propagated northwestward into the western termination of the Keuper sediments as deformation progressed during Lutetian and Bartonian times, and $\mathrm{CW}$ vertical axis rotation increased.

[91] The restored map at early Lutetian times depicts the original position of the earliest structures of the Gavarnie thrust sheet once the Peña Montañesa-Montsec thrust sheet was already emplaced (Figure 15c). The Montsec thrust was connected with its western continuation (Peña Montañesa thrust) along a slightly oblique, long ramp, showing a primary curvature. The buried oblique ramp determined the transition between the fluvio-deltaic systems deposited on top of the Graus-Tremp piggyback Basin and the slope systems of the Ainsa Basin. The growing Mediano and Añisclo 
anticlines controlled sedimentation of slope turbidites of the Ainsa Basin. Nevertheless, they were connected with their deeper equivalents of the Jaca Basin as there were no transversal structural barriers (Figure 15c).

\subsection{Origin of Curvature and the Influence of Detachments}

[92] Timing and spatial relations of paleomagnetic data with respect to the trend of the structures indicate that curvature developed during thrusting and folding within the Ainsa Oblique Zone, which eliminates models of primary curvatures and secondary oroclines. Moreover, the fact that the Sobrarbe folds constitute a coherent structural unit at the eastern part of the Gavarnie thrust sheet rules out previous interpretations that consider any of the major folds of the Sobrarbe system (e.g., Mediano or Boltaña anticlines) as related to main oblique ramps [e.g., Cámara and Klimowitz, 1985; Mutti et al., 1988; Anastasio and Holl, 2001].

[93] Layer parallel shortening directions can be derived from axis parallel pressure solution cleavage (Figures 2 and 3) [Holl and Anastasio, 1995a, 1995b; Tavani et al., 2006], fault assemblages, twinned calcite grains, and AMS. The maximum shortening direction is subperpendicular to the structural trend around the Ainsa Oblique Zone and westward, defining a radial pattern [Parés and Dinarès-Turell, 1993; Holl and Anastasio, 1995b; Tavani et al., 2006; Mochales et al., 2010]. These observations rule out progressive curved models with parallel thrust slip. Moreover, parallel thrust slip models require a significant distributed longitudinal stretching to account for the observed vertical axis rotations, whereas the amount of extension parallel to the Añisclo and Boltaña anticlines has been quantified as less as $0.5 \%$ [Tavani et al., 2006, 2012]. This leaves only progressive curvature models that combine divergent emplacement and differential shortening [Yonkee and Weil, 2010b] as the kinematic model that suitably accounts for the obliquity and curvature of the Ainsa Oblique Zone and the related major thrust salient of the south central Pyrenees.

[94] Notwithstanding, primary curvature would have had a moderate contribution to the final geometry of the thrust salient (Figures 15c and 16).

[95] Furthermore, a divergent emplacement model with curved slip trajectories and progressive westward migration of deformation explains that with a decreasing amount of vertical axis rotation westward, the trend of the folds is still parallel, and consequently, the amount of obliquity of the folds increases also westward. The increase of obliquity westward from the Mediano anticline to the Boltaña anticline, and further west toward the N-S folds of the Sierras Exteriores, is illustrated by the strike test (Figure 14). The slope of the regression for the sites located in the inner salient of the Gavarnie thrust sheet (including La Fueba fold and thrust system and the Mediano anticline) increases if the northernmost, possibly remagnetized sites are removed (Figure 14). On the contrary, if the sites along the younger Boltaña anticline are included, the slope decreases, demonstrating a higher primary contribution of the curvature toward the external parts of the Gavarnie thrust sheet. Finally, a progressive model of curvature with divergent thrust trajectories explains the observed strain pattern in the Sobrarbe anticlines. Divergent thrust slip requires longitudinal extension at the structural bends (Figures 13 and 15a). The Balupor-
San Marzial faults are the result of such extension in the northern bend. They were synchronous with the vertical axis rotation and folding. The location of these extensional faults was controlled by the western limit of the Keuper evaporites, which in turn also controlled the position of the structural bend. In the southern bend, the transverse extensional faults and the salt diapirs (e.g., Clamosa) record strike parallel extension during vertical axis rotation (Figure 15). The amount of extension, of approximately $12 \mathrm{~km}$, as estimated by the width of the diapirs, is consistent with the calculated thrust displacement and thrust trajectories (Figure 15a). Diapirs were enhanced in the southern bend by a thicker salt layer, whereas in the northern bend the reduced thickness of Keuper sediments inhibited the development of salt structures. The edge of the Keuper sediments not only controlled the location of the northern bend of the Ainsa Oblique Zone and the extensional faults but also a change of the structural style from local to regional scale. The high amplitude Añisclo and Boltaña anticlines, cored by Keuper salts, are replaced along the northern bend by a belt of smaller folds and a widespread pressure solution cleavage (Figures 2 and 11).

[96] At a regional scale, the presence of the Triassic detachment level at the bottom of the Mesozoic stratigraphic succession favored the antiformal stack geometry of the basement-involved thrust sheets of the central Pyrenees [Beaumont et al., 2000] and its absence to the west is responsible for the change in geometry of the thrust system to form an imbricate stack (Figure 1).

\subsection{Thrust Displacement and Displacement Gradient}

[97] A significant thrust displacement gradient is necessary to explain the paleomagnetic and structural data in the Ainsa Oblique Zone. A displacement gradient of $44.5 \mathrm{~km}$ has been calculated between 48 and 37 Ma to develop the structures of the Ainsa Oblique Zone and the coeval $\mathrm{CW}$ vertical axis rotation (Figure 16). If we add to this a known minimum displacement of $5 \mathrm{~km}$ for the Gavarnie thrust west of the Ainsa Oblique Zone [Teixell, 1996], a total minimum thrust displacement of $49.5 \mathrm{~km}$ for the Serres Marginals thrust system during the early Lutetian-late Bartonian time span is obtained. This displacement is probably greater as shortening related with the Gavarnie thrust and related folds is also greater. The estimated $44.5 \mathrm{~km}$ of differential shortening during this interval (9Ma) occurred by further southward displacement of the Serres Marginals thrust sheet on top of the Keuper salts with respect to its western equivalent (Gavarnie-Sierras Exteriores thrust sheet) west of the Ainsa Oblique Zone, where the Triassic evaporites are absent. The previously emplaced Montsec-Peña Montañesa and BóixolsCotiella thrust sheets were transported piggyback and bent to form a prominent thrust salient synchronously with the development and $\mathrm{CW}$ vertical axis rotation of the Ainsa Oblique Zone at the eastern part of the Gavarnie thrust sheet (Figures 14, 15, and 16).

[98] During this time, there is no record of a symmetric $\mathrm{CCW}$ vertical axis rotation event at the eastern edge of the central Pyrenean thrust salient (the so-called South Pyrenean Central Unit, Figure 1). There, the Triassic salts continue eastward at the bottom of the Mesozoic succession and the age of CCW vertical axis rotation is younger [Sussman et al., 2004] and coeval with the second Late EoceneOligocene rotation event. This $\mathrm{CCW}$ vertical axis rotation 


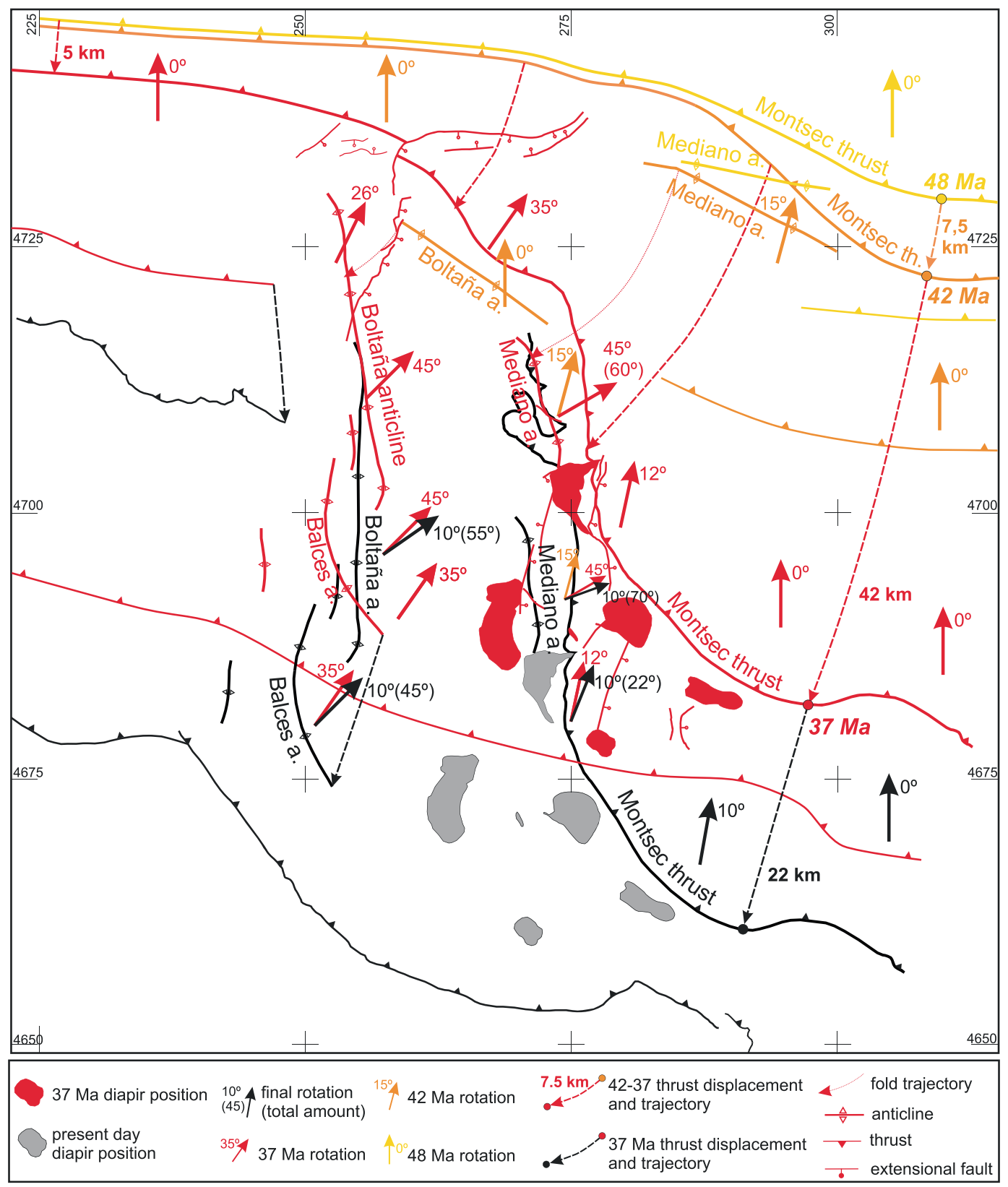

Figure 16. Synthesis of the evolution of the study area during the different stages ( $48 \mathrm{Ma}, 42 \mathrm{Ma}, 37 \mathrm{Ma}$ and present day). Structures and arrows depicting $\mathrm{CW}$ vertical axis rotation have been colored for each stage. The Montsec thrust has been depicted as a passive marker as a reference for the rotation of preGavarnie structures during the differential displacement on the Gavarnie thrust (that led to the $\mathrm{CW}$ vertical axis rotation and the formation of the Ainsa Oblique Zone structures).

event post dates fold growth of the Ainsa Oblique Zone and is related with differential displacement of the sole thrust system on top of the Priabonian-Lower Oligocene salts and their lateral equivalent sediments. These observations, along with the sinchronicity of vertical axis rotation and post-Montsec fold growth, rule out the interpretations that link the obliquity of the Sobrarbe fold system to the emplacement of the Montsec-Peña Montañesa thrust sheet [Séguret, 1972; Farrell et al., 1987; Bentham et al., 1992; Soto et al., 2002; Mochales et al., 2012b].

[99] A minimum differential displacement of $22 \mathrm{~km}$ has been estimated to account for the youngest (Priabonian-
Oligocene) CW vertical axis rotation. This displacement and the related gradient were produced by the Priabonian salt Basin configuration and its associated lateral strength variations. This rotation resulted into a wider and lower amplitude thrust salient (the rotation pinpoints were located about $250 \mathrm{~km}$ apart, beyond the studied area) and was superimposed on the previous curved folds and thrusts of the Ainsa Oblique Zone (Figure 16).

[100] Taking into consideration both rotational events, a total differential displacement of $66.5 \mathrm{~km}$ across the Ainsa Oblique Zone is required to explain the structural, sedimentological, and paleomagnetic data. A possible explanation for 
this differential displacement gradient is the difference in total shortening along the Pyrenean orogeny, as is expected from the work by Teixell [1998] and Beaumont et al. [2000], who estimated shortening to be of $80 \mathrm{~km}$ west of the Ainsa Oblique Zone and $165 \mathrm{~km}$ east of the Ainsa Oblique Zone respectively (Figure 1). The calculated $71.5 \mathrm{~km}$ of total displacement on the Serres Marginals thrust sheet is also consistent with the estimated thrust displacements by Beaumont et al. [2000] along the ECORS cross section for the Middle Eocene-Oligocene interval.

[101] If the difference in shortening is related to the underthrusting of basement units, basement stacking in the central Pyrenees could provide the excess mass necessary to compensate the deficit caused by vertical axis rotation. Alternatively, as the rotation was controlled by the distribution of the detachment horizons in the cover succession (Triassic and Priabonian salts), the displacement gradient could be compensated by an increase of thrust displacement in the Axial Zone and northern Pyrenees west of the Ainsa Oblique Zone.

\section{Conclusions}

[102] Integration of structural, sedimentological, and paleomagnetic data reveals a systematic relationship between the structures of the Ainsa Oblique Zone, their temporal evolution, the strain history, and vertical axis rotation and remagnetization. The kinematic model that best matches all the observed data is that of a curved fold and thrust belt developed by progressive curvature with a divergent thrust transport direction.

[103] This kinematic evolution resulted from along-strike differential shortening localized by the distribution of the weak evaporite horizons at the bottom of the detached Mesozoic and Paleogene successions during two main rotational events. During the main event, Middle Eocene in age (Lutetian to Priabonian), the fold and thrusts of the Ainsa Oblique Zone, at the eastern part of the Gavarnie thrust sheet, developed synchronously with up to $60^{\circ}$ of CW vertical axis rotation in response to an estimated $44.5 \mathrm{~km}$ of differential displacement along the orogen. The second rotation event, Late Eocene-Oligocene in age, added a further $10^{\circ}$ of $\mathrm{CW}$ vertical axis rotation associated to a displacement gradient of $22 \mathrm{~km}$. A total differential thrust displacement of $66.5 \mathrm{~km}$ across the entire Ainsa Oblique Zone has been estimated to account for the observed structural pattern and the $\mathrm{CW}$ vertical axis rotation of the restored mean magnetic declinations (Figure 16). Folding and vertical axis rotation in the Ainsa Oblique Zone were also accompanied by the formation of mesostructures (cleavage and fractures). Intense layer parallel shortening related to cleavage (over $20 \%$ ) led to the remagnetization of the internal areas of the Gavarnie thrust sheet during its emplacement and synchronous with the CW vertical axis rotation of the Sobrarbe folds.

[104] Space problems related to the regional CW vertical axis rotations were compensated by the formation of the Balupor and San Marzial extensional faults in the northern bend and transverse extensional faults and diapirs in the southern bend where Triassic salts were significantly thicker (Figure 16). In addition, oblique to strike-slip displacements reactivated previously developed thrusts during the $\mathrm{CW}$ vertical axis rotation.
[105] Among the different analyzed factors, the most significant mechanism controlling the kinematic evolution of the Ainsa Oblique Zone is the distribution and strength variations of the Triassic sediments at the basal detachment. They not only controlled the location and the structural pattern of the curved structures but also determined a change in the structural style at a crustal scale of the Pyrenean thrust system at both sides of the Ainsa Oblique Zone. This study also illustrates the changing synorogenic topography of a foreland basin setting associated with a progressive curved contractional system and the power of the understanding of its kinematics to unravel the dispersal patterns of the sedimentary systems.

[106] Finally, this study emphasizes the importance of integrating sedimentological, structural, and paleomagnetic data to understand the kinematics of curved contractional systems. It also highlights that statistical analysis of paleomagnetic data has to be constrained by structural and stratigraphic data in order to avoid conclusions that contradict geological field observations and regional constraints.

[107] Acknowledgments. This work was funded by the project INTECTOSAL (CGL2010-21968-C02-01) and by the "Grup de Recerca de Geodinàmica i Anàlisi de Conques 2009SGR1198" Secretaria d'Universitat i Recerca del Departament d'Economia i Coneixement de la Generalitat de Catalunya. Josep Poblet acknowledges financial support by research projects: "Geociencias en Iberia: estudios integrados de topografia y evolución 4D [TOPO-IBERIA]" (CSD2006-041) and "Desarrollo de fracturas y venas asociadas al plegamiento [FRAVEPLE]" (CGL201123628) funded by Spanish Ministries. Thanks to the Paleomagnetic Laboratory of Barcelona (CCiT UB-CSIC) where the paleomagnetic analyses were carried out. Midland Valley is thanked for providing the 2DMove software. We thank Emilio Pueyo, Antonio Casas, and an anonymous reviewer for the fruitful and constructive revisions which have significantly improved the original submitted manuscript.

\section{References}

Allerton, S. (1998), Geometry and kinematics of vertical-axis rotations in fold and thrust belts, Tectonophysics, 299, 15-30.

Anastasio, D. J., and J. E. Holl (2001), Transverse fold evolution in the External Sierras, southern Pyrenees, Spain, J. Struct. Geol., 23, 379-392.

Arbués, P., D. Mellere, O. Falivene, O. Fernández-Bellón, J. A. Muñoz, M. Marzo, and J. M. de Gibert (2007), Context and architecture of the Ainsa-1-quarry channel complex, Spain, in Atlas of Deep-Water Outcrops, edited by T. H. Nilsen et al. AAPG Studies in Geology, vol. 56, CD-ROM, 20 pp ,AAPG-Shell Explor. and Prod., Tulsa, Okla.

Arbués, P., M. Butillé, M. López-Blanco, M. Marzo, O. Monleon, J. A. Muñoz, and J. Serra-Kiel (2011), Exploring the relationships between deepwater and shallow-marine deposits in the Aínsa piggy-back basin fill (Eocene, South- Pyrenean Foreland Basin), in Post-Meeting Field Trips Guidebook, 28th IAS Meeting, Zaragoza, vol. 8, edited by C. Arenas, L. Pomar and F. Colombo, pp. 199-240, Soc. Geol. de España, Geo-guias Zaragoza, Spain.

Baceta, J. I., V. Pujalte, J. Serra-Kiel, A. Robador, and X. Orue-Etxebarria (2004), El Maastrichtiense final- Paleoceno e Ilerdiense inferior de la Cordillera Pirenaica, in Geología de España, edited by J. A. Vera, pp. 308-313, SGE-IGME, Madrid, Spain.

Barnolas, A., and A. Teixell (1994), Platform sedimentation and collapse in a carbonate-dominated margin of a foreland basin (Jaca Basin, Eocene, southern Pyrenees), Geology, 22, 1107-1110.

Barnolas, A., and I. Gil-Peña (2001), Ejemplos de relleno sedimentario multiepisódico en una cuenca de antepaís fragmentada: La Cuenca Surpirenaica, Bol. Geol. Min., 112(3), 17-38.

Barnolas, A., J. M. Samsó, A. Teixell, J. Tosquella, and M. Zamorano (1991), Evolución sedimentaria entre la Cuenca de Graus-Tremp y la Cuenca de Jaca-Pamplona, in I Congreso del Grupo Español del Terciario, Guide Book 1, 123 pp., F. Colombo, Vic, Spain.

Beamud, E., M. Garcés, L. Cabrera, J. A. Muñoz, and Y. Almar (2003), A new middle to late Eocene continental chronostratigraphy from NE Spain, Earth Planet. Sci. Lett., 216, 501-514.

Beaumont, C., J. A. Muñoz, J. Hamilton, and P. Fullsack (2000), Factors controlling the Alpine evolution of the central Pyrenees inferred from a 


\section{MUÑOZ ET AL.: PALEOMAGNETISM IN S PYRENEES}

comparison of observations and geodynamical models, J. Geophys. Res., 105(B4), 8121-8145.

Bentham, P. (1992), The tectono-stratigraphic development of the western oblique ramp of the South-Central Pyrenean thrust system, northern Spain, PhD thesis, 253 pp., Univ. of S. Calif.

Bentham, P. A., and D. W. Burbank (1996), Chronology of Eocene foreland basin evolution along the western oblique margin of the South-Central Pyrenees, in Tertiary Basins of Spain, edited by P. F. Friend and C. J. Dabrio, pp. 144-152, Cambridge Univ. Press, New York.

Bentham, P. A., D. W. Burbank, and C. Puigdefäbregas (1992), Temporal and spatial controls on the alluvial architecture of an axial drainage system: Late Eocene Escanilla Formation, southern Pyrenean foreland basin, Spain, Basin Res., 4, 335-352.

Cámara, P., and J. Klimowitz (1985), Interpretación geodinámica de la vertiente centro-occidental surpirenaica (Cuencas de Jaca-Tremp), Estud. Geol., 41, 391-404.

Casas, A. M., R. Soto, and B. Martínez-Peña (2002), Geometrical relationships between unconformities and subsequent folding: The Arro fold system (southern Pyrenees), C.R. Geosci., 334, 765-772.

Charlesworth, H., D. Cruden, J. Ramsden, and Q. Huang (1989), ORIENT: An interactive Fortran 77 program for processing orientations on a microcomputer, Comput. Geosci., 15, 275-293.

Choukroune, P. (1976), Structure et évolution tectonique de la zone nordpyrénéene. Analyse de la déformation dans une portion de chaîne à schistosité subverticale, Mém. Soc. Géol. France, 127, 116 pp.

Choukroune, P., and M. Séguret (1973), Carte structurale des Pyrénées, 1/500.000, Univ. of Montpellier - ELF Aquitaine, France.

Costa, E., M. Garcés, M. López-Blanco, J. Serra-Kiel, G. Bernaola, L. Cabrera, and E. Beamud (2013), The Bartonian-Priabonian marine record of the eastern South Pyrenean Foreland Basin (NE Spain): A new calibration of the larger foraminifers and calcareous nannofossil biozonation, Geol. Acta, 11(2), 177-193.

De Federico, A. (1981), La sedimentación de talud en el sector occidental de la cuenca Paleógena de Aínsa. 12, 271 pp., Publ. of Geol., Univ. of Barcelona, Spain.

Demarest, H. H. (1983), Error analysis for the determination of tectonic rotation from paleomagnetic data, J. Geophys. Res., 88(B5), 4321-4328.

Dinarès, J., E. McClelland, and P. Santanach (1992), Contrasting rotations within thrust sheets and kinematics of thrust tectonics as derived from palaeomagnetic data: An example from the Southern Pyrenees, in Thrust Tectonics, edited by K. R. McClay, pp. 235-246, Chapman and Hall, London.

Dinarès-Turell, J. (1992), Paleomagnetisme a les unitats sudpirinenques superiors, Implicacions estructurals, $\mathrm{PhD}$ thesis, 462 pp., Univ. of Barcelona, Spain.

Dinarès-Turell, J., and J. M. Parés (1992), The use of AMS to determine the petrofabric in weakly deformed rocks: A case study from the Eocene in the Ainsa Basin (central Pyrenees), Geogaceta, 12, 22-25.

Dreyer, T., J. Corregidor, P. Arbués, and C. Puigdefäbregas (1999), Architecture of the tectonically influenced Sobrarbe deltaic complex in the Ainsa Basin, northern Spain, Sediment. Geol., 127, 127-169.

Eldredge, S., V. Bachtadse, and R. Van der Voo (1985), Paleomagnetism and the oroclines hypothesis, Tectonophysics, 119, 153-179, doi:10.1016/00401951(85)90037-X.

Elliot, D. (1976), The motion of thrust sheets, J. Geophys. Res., 81, 949-963.

Elmore, R. D., A. R. Muxworthy, and M. Aldana (2012), Remagnetization and chemical alteration of sedimentary rocks, in Remagnetization and Chemical Alteration of Sedimentary Rocks, edited by R. D. Elmore, A. R. Muxworthy, and M. Aldana, Geol. Soc. London Spec. Publ., 371, 1-21.

Enkin, R. J. (2003), The direction-correction tilt test: An all-purpose tilt/fold test for paleomagnetic studies, Earth Planet. Sci. Lett., 212(1-2), 151-166.

Evans, S. C., and R. D. Elmore (2006), Fluid control of localized mineral domains in limestone pressure solution structures, J. Struct. Geol., 28, 284-301.

Falivene, O., P. Arbués, J. Ledo, B. Benjumea, J. A. Muñoz, O. Fernández, and S. Martínez (2010), Synthetic seismic models from outcrop-derived reservoir-scale three-dimensional facies models: The Eocene Ainsa turbidite system (southern Pyrenees), AAPG Bull., 94(3), 317-343.

Farrell, S. G., G. D. Williams, and C. D. Atkinson (1987), Constraints on the age of movement of the Montsec and Cotiella Thrusts, south central Pyrenees, Spain, J. Geol. Soc. London, 144, 907-914.

Fernández, O., J. A. Muñoz, P. Arbués, O. Falivene, and M. Marzo (2004), Three-dimensional reconstruction of geological surfaces: An example of growth strata and turbidite systems from the Ainsa basin (Pyrenees, Spain), Am. Assoc. Pet. Geol. Bull., 88(8), 1049-1068.

Fernández, O., J. A. Muñoz, P. Arbués, and O. Falivene (2012), 3-D structure and evolution of an oblique system of relaying folds: The Ainsa basin (Spanish Pyrenees), J. Geol. Soc. London, 169, 545-559, doi:10.1144/ 0016-76492011-068.
Fernández-Bellon, O. (2004), Reconstruction of geological structures in 3D, An example from the Southern Pyrenees, PhD thesis, 321 pp., Univ. of Barcelona, Spain.

Fournier, E. (1905), Études géologiques sur la partie occidentale de la chaîne des Pyrénées entre la vallée d'Aspe et de celle de la Nive, Bull. Soc. Géol. France, 4 Ser., 5, 699-725, Spain.

García-Senz, J. (2002), Cuencas extensivas del cretácico inferior en los Pirineos centrales, formación y subsecuente inversión, $\mathrm{PhD}$ thesis, 310 pp., Univ. of Barcelona.

Garrido-Megías, A. (1973), Estudio geológico y relación entre tectónica y sedimentación del secundario y terciario de la vertiente meridional pirenaica en su zona central (provincias de Huesca y Lérida), PhD thesis, 395 pp., Univ. of Granada, Spain.

Gradstein, F. M., J. G. Ogg, and A. G. Smith (2004), A Geologic Time Scale 2004, 589 pp., Cambridge Univ. Press, Cambridge U.K.

Hindle, H., and M. Burkhard (1999), Strain, displacement and rotation associated with the formation of curvature on fold belts; the example of the Jura arc, J. Struct. Geol., 21, 1089-1101, doi:10.1016/S01918141(99)00021-8.

Hogan, P. J. (1993), Geochronologic, tectonic and stratigraphic evolution of the southwest Pyrenean foreland basin, Northern Spain, PhD thesis, 219 pp., Univ. of S. Calif.

Hogan, P. J., and D. W. Burbank (1996), Evolution of the Jaca piggyback basin and emergence of the External Sierras, southern Pyrenees, in Tertiary Basins of Spain, edited by P. F. Friend and C. J. Dabrio, pp. 153-160, Cambridge Univ. Press Cambridge, U.K.

Holl, J. E., and D. J. Anastasio (1995a), Kinematics around a large-scale oblique ramp, southern Pyrenees, Spain, Tectonics, 16(5), 1368-1379.

Holl, J. E., and D. J. Anastasio (1995b), Cleavage development within a foreland thrust and fold belt, southern Pyrenees, Spain, J. Struct. Geol., 17(3), 357-369.

Labaume, P., M. Séguret, and C. Seyve (1985), Evolution of a turbiditic foreland basin and analogy with an accretionary prism: Example of the Eocene South-Pyrenean basin, Tectonics, 4(7), 661-685, doi:10.1029/ TC004i007p00661.

Lacroix, B., M. Buatier, P. Labaume, A. Travé, M. Dubois, D. Charpentier, S. Ventalon, and D. Convert-Gaubier (2011), Microtectonic and geochemical characterization of thrusting in a foreland basin: Example of the SouthPyrenean orogenic wedge (Spain), J. Struct. Geol., 33, 1359-1377.

Lanaja, J. M., and A. Navarro (1987), Contribución de la Exploración Petrolifera al Conocimiento de la Geología de España, 465 pp., Inst. Geol. and Min. of España, Madrid.

Larrasoaña, J. C., J. M. Parés, H. Millán, J. del Valle, and E. L. Pueyo (2003), Paleomagnetic, structural, and stratigraphic constraints on the traverse fault kinematics during basin inversion: The Pamplona Fault (Pyrenees, north Spain), Tectonics, 22(6), 1071, doi:10.1029/2002TC001446.

López, M. A., C. Oliván, B. Oliva, E. L. Pueyo, and the GeoKin3DPyr working group (2008), Pyrenean Paleomagnetic databases, Geotemas, 10, 1219-1222.

López-Blanco, M., M. Marzo, and J. A. Muñoz (2003), Low-amplitude, synsedimentary folding of a deltaic complex: Roda sandstone (lower Eocene), South-Pyrenean Foreland Basin, Basin Res., 15(1), 73-95.

Lowrie, W., and A. M. Hirt (1986), Paleomagnetism in arcuate mountain belts, in The Origin of Arcs, Dev. Geotectonics, vol. 21 pp. 141-158, Elseveier, Amsterdam.

Luzón, A. (2005), Oligocene-Miocene alluvial sedimentation in the northern Ebro Basin, NE Spain: Tectonic control and palaeogeographical evolution, Sediment. Geol., 177, 19-39.

Macedo, J., and S. Marshak (1999), Controls on the geometry of fold-thrust belt salients, Geol. Soc. Am. Bull., 111, 1808-1822.

Marshak, S. (2004), Salients, recesses, arcs, oroclines, and syntaxes - A review of ideas concerning the formation of map-view curves in foldthrust belts, in Thrust Tectonics and Hydrocarbon Systems, edited by K. R. McClay, AAPG Mem., 82, 131-156.

Martínez Peña, M. B. (1991), La estructura del límite occidental de la unidad surpirenaica central, PhD thesis, 380 pp., Univ. of Zaragoza, Spain.

Martínez-Peña, M. B., and A. M. Casas-Sainz (2003), Cretaceous-tertiary tectonic inversion of the Cotiella Basin (southern Pyrenees, Spain), Int. J. Earth Sci., 92, 99-113.

Mateu-Vicens, G., L. Pomar, and C. Ferrández (2012), Nummulitic banks in the upper Lutetian "Buil level", Ainsa Basin, South Central Pyrenean Zone: The impact of internal waves, Sedimentology, 59(2), 527-552.

McClay, K., J. A. Muñoz, and J. García-Senz (2004), Extensional salt tectonics in a contractional orogen: A newly identified tectonic event in the Spanish Pyrenees, Geology, 32(9), 737-740.

McFadden, P. L. (1990), A new fold test for paleomagnetic studies, Geophys. J. Int., 103(1), 163-169, doi:10.1111/j.1365-246X.1990.tb01761.x.

Megías, A. G. (1982), Nueva hipótesis paleogeográfica sobre el cretácico surpirenaico, Cuadernos Geol. Ibérica, 8, 1005-1015. 
Mey, P. H. W., P. J. C. Nagtegaal, K. J. Roberti, and J. J. A. Hartevelt (1968), Lithostratigraphic subdivision of post-Hercynian deposits in the south-central Pyrenees, Spain, Leidse Geologische Mededelingen, $431,221-228$.

Millán, H. (1996) Estructura del frente de cabalgamiento surpirenaico en las Sierras Exteriores Aragonesas, $\mathrm{PhD}$ thesis, 213 pp., Univ. of Zaragoza.

Millán, H., E. L. Pueyo, M. Aurell, A. Luzón, B. Oliva, M. B. Martínez-Peña, and J. Pocoví (2000), Actividad tectónica registrada en los depósitos terciarios del frente meridional del Pirineo central, Rev. Soc. Geol. España, 13, 279-300.

Millán, H., B. Oliva, and J. Pocoví (2006), La transversal de GavarnieGuara. Estructura y edad de los mantos de Gavarnie, Guara-Gèdre y Guarga (Pirineo centro-occidental), Geogaceta, 40, 35-37.

Mochales, T. (2011), Chronostratigraphy, vertical-axis rotations and AMS in the Boltaña anticline (Southern Pyrenees): Kinematic implications, PhD thesis, 222 pp., Univ. of Zaragoza, Spain.

Mochales, T., E. L. Pueyo, A. M. Casas, A. Barnolas, and B. Oliva-Urcia (2010), Anisotropic magnetic susceptibility record of the kinematics of the Boltaña Anticline (Southern Pyrenees), Geol. J., 45, 562-581, doi:10.1002/gj.1207.

Mochales, T., A. Barnolas, E. L. Pueyo, J. Serra-Kiel, A. M. Casas, J. M. Samsó, J. Ramajo, and J. Sanjuán (2012a), Chronostratigraphy of the Boltaña anticline and the Ainsa Basin (Southern Pyrenees), Geol. Soc. Am. Bull., 124(7-8), 1229-1250, doi:10.1130/B30418.1.

Mochales, T., A. M. Casas, E. L. Pueyo, and A. Barnolas (2012b), Rotational velocity for oblique structures (Boltaña anticline, Southern Pyrenees), J. Struct. Geol., 35, 2-16, doi:10.1016/j.jsg.2011.11.009.

Montes, M. J. (1992), Sistemas deposicionales en el Eoceno medio Oligoceno del Sinclinorio-Río del Guarga (Cuenca de Jaca, Pirineo Central), in Simposios, III Congreso Geológico de España y VIII Congreso Latinoamericano de Geología. Tomo 2, pp. 150-160, Salamanca, Spain.

Muñoz, J. A. (1992), Evolution of a continental collision belt: ECORSPyrenees crustal balanced section, in Thrust Tectonics, edited by K. R. McClay, pp. 235-246, Chapman and Hall, London.

Muñoz, J. A. (2002), The Pyrenees, in The Geology of Spain, edited by W. Gibbons and T. Moreno, pp. 370-385, Geol. Soc. of London, London.

Muñoz, J. A., K. R. McClay, and J. Poblet (1994), Synchronous extension and contraction in frontal thrust sheets of the Spanish Pyrenees, Geology, 22, 921-924.

Muñoz, J. A., P. J. Coney, K. R. McClay, and C. A. Evenchick (1997), Discussion on syntectonic burial and post-tectonic exhumation of the southern Pyrenees foreland fold-thrust belt, J. Geol. Soc. London, 154, $361-365$

Muñoz, J. A., P. Arbués, and J. Serra-Kiel (1998), The Ainsa Basin and the Sobrarbe oblique platform sequences deposited synchronously with a submarine emergent thrust system, in Field Trip Guide Book, edited by A. Meléndez-Hevia and A. R. Soria, pp. 213-223, 15th IAS Congress, Alicante, Spain.

Mutti, E., H. Luterbacher, J. Ferrer, and J. Rosell (1972), Schema stratigrafico e lineamenti di facies di Paleogene marino nella zona central subpirenaica tra Tremp (Catalogna) e Pamplona (Navarra), Mem. Soc. Geol. It., 11, 391-416.

Mutti, E., E. Remacha, M. Sgavetti, J. Rosell, R. Valloni, and M. Zamorano (1985), Stratigraphy and facies characteristics of the Eocene Hecho Group turbidite systems, south-central Pyrenees. Excursion 12, in 6th European Regional Meeting Excursion Guidebook - IAS, edited by M. D. Milà and J. Rosell, pp. 519-576, Inst. Estud. Ilerdencs, Lleida, Spain.

Mutti E., M. Séguret, and M. Sgavetti (1988), Sedimentation and deformation in the Tertiary sequences of the southern Pyrenees, AAPG Mediteranean Basins Conference, Nice, Field Trip Guidebook 7 , $169 \mathrm{pp}$.

Nijman, W., and S. D. Nio (1975), The Eocene Motañana delta, in Sedimentary evolution of the Paleogene South Pyrenean Basin, edited by J. Rosell and C. Puigdefäbregas, 56 pp. IAS 9th International Congress Nice, B.

Noel, M., and C. M. Batt (1990), A method for correcting geographically separated remanence directions for the purpose of archaeomagnetic dating, Geophys. J. Int., 70, 201-204.

Oliva-Urcia, B. (2004), Geometría y cinemática rotacional en las Sierras Interiores y Zona Axial (sector de Bielsa) a partir del análisis estructural y paleomagnético, $\mathrm{PhD}$ thesis, 290 pp., Univ. of Zaragoza, Spain.

Oliva-Urcia, B., and E. L. Pueyo (2007a), Gradient of shortening and vertical-axis rotations in the Southern Pyrenees (Spain), insights from a synthesis of paleomagnetic data, Rev. Soc. Geol. Esp., 20(1-2), $105-118$.

Oliva-Urcia, B., and E. L. Pueyo (2007b), Rotational basement kinematics deduced from remagnetized cover rocks (Internal Sierras, southwestern Pyrenees), Tectonics, 26, TC4014, doi: 10.1029/2006TC001955.
Oliva-Urcia, B., E. L. Pueyo, and J. C. Larrasoaña (2008), Magnetic reorientation induced by pressure solution: A potential mechanism for orogenic-scale remagnetizations, Earth Planet. Sci. Lett., 265, $525-534$.

Oliva-Urcia, B., C. Larrasoaña, E. L. Pueyo, A. Gil-Imaz, P. Mata, J. M. Parés, and A. M. Schleicher (2009), Complex magnetic subfabrics in a well-developed cleavage domain, Internal Sierras (Pyrenees, Spain), J. Struct. Geol., 31(2), 163-176.

Oliva-Urcia, B., A. M. Casas, E. L. Pueyo, and A. Pocoví (2012a), Structural and paleomagnetic evidence for non-rotational kinematics in the western termination of the External Sierras (southwestern central Pyrenees), Geol. Acta, 10(2), 125-144, doi:10.1344/105.000001704.

Oliva-Urcia, B., E. L. Pueyo, J. C. Larrasoaña, A. M. Casas, T. Román-Berdiel, R. Van der Voo, and R. Scholger (2012b), New and revisited paleomagnetic data from Permian-Triassic red beds: Two kinematic domains in the west-central Pyrenees, Tectonophysics, 522-523, 158-175, doi:10.1016/j.tecto.2011.11.023.

Oms, O., J. Dinarès-Turell, and E. Remacha (2003), Magnetic stratigraphy from deep clastic turbidites: An example from the Eocene Hecho Group (Southern Pyrenees), Stud. Geophys. Geod., 47, 275-288.

Parés, J. M., and J. Dinarès-Turell (1993), Magnetic fabric in two sedimentary rock-types from the southern Pyrenees, J. Geomag. Geoelectr, 45(2), 193-205.

Pascual, J. O., J. M. Parés, C. G. Langereis, and J. D. A. Zijderveld (1992), Magnetostratigraphy and rock magnetism of the Ilerdian stratotype at Tremp, Spain, Phys. Earth Planet. Inter., 74, 139-157.

Poblet, J., J. A. Muñoz, A. Travé, and J. Serra-Kiel (1998), Quantifying the kinematics of detachment folds using three-dimensional geometry: Application to the Mediano anticline (Pyrenees, Spain), Geol. Soc. Am. Bull., 110(1), 111-125.

Pueyo, E. (2000), Rotaciones paleomagnéticas en sistemas de pliegues y cabalgamientos. Tipos, causas, significado y aplicaciones. (Ejemplos de las Sierras Exteriores y Cuenca de Jaca, Pirineo Aragonés), $\mathrm{PhD}$ thesis, 296 pp., Univ. of Zaragoza, Spain.

Pueyo, E. L., H. Millán, A. Pocoví, and J. M. Parés (1997), Cinemática rotacional del cabalgamiento basal surpirenaico en las Sierras Exteriores Aragonesas: Datos magnetotectónicos, Acta Geol. Hisp., 32(3-4), 237-256.

Pueyo, E. L., H. Millán, and A. Pocoví (2002), Rotation velocity of a thrust: A paleomagnetic study in the External Sierras (Southern Pyrenees) Sediment. Geol., 146, 191-208.

Pueyo, E. L., J. M. Parés, H. Millán, and A. Pocoví (2003a), Conical folds and apparent rotations in paleomagnetism (A case studied in the Southern Pyrenees), in Paleomagnetism Applied to Tectonics; A Tribute to Rob Van der Voo, edited by C. Mac Niocaill, T. H. Torsvik, and B. A. van der Pluijm, Tectonophysics, 362(1-4), 345-366.

Pueyo, E. L., A. Pocoví, J. M. Parés, H. Millán, and J. C. Larrasoaña (2003b), Thrust ramp geometry and spurious rotations of paleomagnetic vectors, Stud. Geophys. Geodet., 47, 331-357.

Pueyo, E. L., A. Pocoví, H. Millán, and A. J. Sussman (2004), Map-view models for correcting and calculating shortening estimates in rotated thrust fronts using paleomagnetic data, in Orogenic Curvature: Integrating Paleomagnetic and Structural Analyses, edited by A. J. Sussman and A. B. Weil, Spec. Pap. Geol. Soc. Am., 383, 55-71.

Pueyo-Anchuela, O., E. L. Pueyo, A. Pocoví, and A. Gil-Imaz (2012), Vertical axis rotations in fold and thrust belts: Comparison of AMS and paleomagnetic data in the Western External Sierras (Southern Pyrenees) Tectonophysics, 532-535, 119-133, doi:10.1016/j.tecto.2012.01.023.

Puigdefàbregas, C. (1975), La sedimentación molásica en la cuenca de Jaca, Pirineos, 104, 1-188.

Ramón, M. J., E. L. Pueyo, J. L. Briz, A. Pocoví, and J. C. Ciria (2012), Flexural unfolding in 3D using paleomagnetic vectors, J. Struct. Geol., 35, 28-39, doi:10.1016/j.jsg.2011.11.015.

Ríos Aragüés, L. M., J. M. Lanaja del Busto, J. M. Ríos Mitchell, and F. J. Marín Blanco (1982a), Mapa geológico de España 1:50000. Segunda serie. Hoja 179, Bielsa. IGME.

Ríos Aragüés, L. M., J. M. Lanaja del Busto, and E. Frutos Domingo (1982b), Mapa geológico de España 1:50000. Segunda serie. Hoja 178 Broto. IGME.

Robador, A. (2008), El Paleoceno e Ilerdiense inferior del Pirineo occidental: Estratigrafía y sedimentología, Publicaciones del Instituto Geológico y Minero de España, serie Tesis Doctorales 12, 285 pp., Madrid, Spain.

Rodríguez-Pintó, A., E. L. Pueyo, J. Serra-Kiel, J. M. Samsó, A. Barnolas, and A. Pocoví (2012), Lutetian magnetostratigraphic calibration of larger foraminifera zonation (SBZ) in the Southern Pyrenees: The Isuela section, Palaeogeogr. Palaeoclimatol. Palaeoecol., 333-334, $107-120$

Rodríguez-Pintó, A., E. L. Pueyo, A. Pocoví, M. J. Ramón, and B. Oliva-Urcia (2013), Structural control on overlapped paleomagnetic 


\section{MUÑOZ ET AL.: PALEOMAGNETISM IN S PYRENEES}

vectors: A case study in the Balzes anticline (Southern Pyrenees), Phys. Earth Planet. Inter., 215, 43-57, doi:10.1016/j.pepi.2012.10.005.

Roest, W. R., and S. P. Srivastava (1991), Kinematics of the plate boundaries between Eurasia, Iberia, and Africa in the North Atlantic from the Late Cretaceous to the present, Geology, 19(6), 613-616.

Rosenbaum, G., G. S. Lister, and C. Duboz (2002), Relative motions of Africa, Iberia and Europe during Alpine orogeny, Tectonophysics, 359, 117-129.

Schwartz, S. Y., and R. Van der Voo (1983), Paleomagnetic evaluation of the orocline hypothesis in the central and southern Appalachians, Geophys. Res. Lett., 10, 505-508, doi:10.1029/GL010i007p00505.

Séguret, M. (1972), Étude tectonique des nappes et séries décollées de la partie centrale du versant sud des Pyrénées - caractère synsédimentaire, rôle de la compression et de la gravité, Série géologie structurale, 2 , France, 155 pp., Publications de 1'Universite des Sciences et Techniques du Languedoc (USTELA), Montpellier, France.

Serra-Kiel, J., J. I. Canudo, J. Dinarès, E. Molina, N. Ortiz, J. O. Pascual, J. M. Samsó, and J. Tosquella (1994), Cronoestratigrafía de los sedimentos marinos del terciario inferior de la cuenca de Graus-Tremp (Zona Central Surpirenaica), Rev. Soc. Geol. Esp., 7, 273-297.

Soler-Sampere, M., and A. Garrido (1970), La terminación occidental del manto de Cotiella, Pirineos, 98, 5-12.

Soto, R., and A. M. Casas (2001), Geometría y cinemática de las estructuras norte-sur de la Cuenca de Aínsa, Rev. Soc. Geol. Esp., 16(3-4), 199-211.

Soto, R., A. M. Casas, F. Storti, and C. Faccenna (2002), Role of lateral thickness variations on the development of oblique structures at the western end of the South Pyrenean Central Unit, Tectonophysics, 350, 215-235.

Soto, R., A. M. Casas-Sainz, and E. L. Pueyo (2006), Along-strike variation of orogenic wedges associated with vertical axis rotations, J. Geophys. Res., 111, B10402, doi:10.1029/2005JB004201.

Storti, F., R. Soto, F. Rossetti, and A. M. Casas-Sainz (2007), Evolution of experimental thrust wedges accreted from along-strike tapered, siliconefloored multilayers, J. Geol. Soc. London, 164, 73-85.

Sussman, A. J., and A. B. Weil (2004), Orogenic curvature: Integrating paleomagnetic and structural analyses, Geol. Soc. Am. Spec. Pap., 383, $258 \mathrm{pp}$.

Sussman, A. J., R. F. Butler, J. Dinarès-Turell, and J. Vergés (2004), Vertical-axis rotation of a foreland fold and implications for orogenic curvature: An example from the Southern Pyrenees, Spain, Earth Planet. Sci. Lett., 218(3-4), 435-449.

Taberner, C., J. Dinarès-Turell, J. Jiménez, and C. Docherty (1999), Basin infill architecture and evolution from magnetostratigraphic cross-basin correlations in the southeastern Pyrenean foreland basin, Geol. Soc. Am. Bull., 11(8), 1155-1174.

Tavani, S., F. Storti, O. Fernández-Bellon, J. A. Muñoz, and F. Salvini (2006), 3-D deformation pattern analysis and evolution of the Añisclo anticline, southern Pyrenees, J. Struct. Geol., 28, 695-712.

Tavani, S., O. Fernández, and J. A. Muñoz (2012), Stress fluctuation during thrust-related folding. Example from the Boltaña Anticline
(Pyrenees, Spain), in Faulting, Fracturing and Igneous Intrusion in the Earth's Crust, edited by D. Healy, et al. Geol. Soc. London Spec. Publ., 367, 131-140.

Teixell, A. (1996), The Ansó transect of the southern Pyrenees: Basement and cover thrust geometries, J. Geol. Soc. London, 153, 301-310.

Teixell, A. (1998), Crustal structure and orogenic material budget in the west central Pyrenees, Tectonics, 17(3), 395-406.

Teixell, A., and A. Barnolas (1995), Significado de la Discordancia de mediano en relación con las estructuras adyacentes (Eoceno, Pirineo Central), Geogaceta, 18, 34-37.

Teixell, A., and J. A. Muñoz (2000), Evolución tectono-sedimentaria del Pirineo meridional durante el Terciario: Una síntesis basada en la transversal del río Noguera Ribagorçana, Rev. Soc. Geol. Esp., 15(2), 251-264.

Travé, A., P. Labaume, F. Calvet, and A. Soler (1997), Sediment dewatering and pore fluid migration along thrust faults in a foreland basin inferred from isotopic and elemental geochemical analyses (Eocene southern Pyrenees, Spain), Tectonophysics, 282, 375-398.

Travé, A., P. Labaume, F. Calvet, A. Soler, J. Tritlla, M. Buatier, J.-L. Potdevin, M. Séguret, S. Raynaud, and L. Briqueu (1998), Fluid migration during Eocene thrust emplacement in the south Pyrenean foreland basin (Spain): An integrated structural, mineralogical and geochemical approach, in Cenozoic Foreland Basins of Western Europe, edited by A. Mascle, C. Puigdefàbregas, and M. Fernández, Spec. Publ. Geol. Soc. Am., 134, 163-188.

Van Lunsen, H. (1970), Geology of the Ara-Cinca region, Spanish Pyrenees, Bull. Soc. Geol. France, VI, (2), 265-271.

Vergés, J. (1993), Estudi tectònic del vessant sud del Pirineu oriental i central, Evolució cinemàtica 3D, PhD thesis, 203 pp., Univ. of Barcelona, Spain.

Vidal, O., H. A. Koyi, and J. A. Muñoz (2009), Formation of orogenperpendicular thrusts due to mechanical contrasts in the basal décollement in the Central External Sierras (Southern Pyrenees, Spain), J. Struct. Geol., 31, 523-539.

Weil, A. B., and A. Sussman (2004), Classification of curved orogens based on the timing relationships between structural development and verticalaxis rotations, in Orogenic Curvature: Integrating Paleomagnetic and Structural Analyses, edited by A. J. Sussman and A. B. Weil, Spec. Pap. Geol. Soc. Am., 383, 1-17.

Weil, A. B., A. Yonkee, and A. Sussman (2010), Reconstructing the kinematic evolution of curved mountain belts: A paleomagnetic study of Triassic red beds from the Wyoming salient, Sevier thrust belt, U.S.A, Geol. Soc. Am. Bull., 122, 3-23, doi:10.1130/B26483.1.

Yonkee, A., and A. B. Weil (2010a), Reconstructing the kinematic evolution of curved mountain belts: Internal strain patterns in the Wyoming salient, Sevier thrust belt, U.S.A, Geol. Soc. Am. Bull., 122(1-2), 24-49, doi:10.1130/B26484.1.

Yonkee, A., and A. B. Weil (2010b), Quantifying vertical- axis rotation in curved orogens: Correlating multiple data sets with a refined weighted least squares strike test, Tectonics, 29, TC3012, doi:10.1029/2008TC002312. 